Nevada

DOE/ N V -5 $24-R E V .1$

Environmental

Restoration

Project

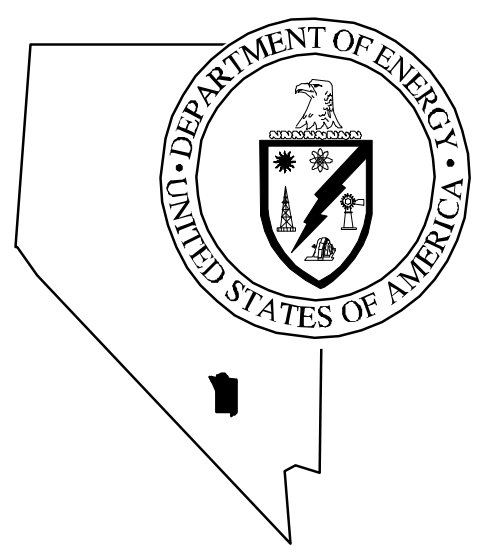

Corrective Action Decision Docum ent for Corrective Action Unit 417: Central N evada Test Area Surface, $\mathrm{N}$ evada

Controlled Copy N 0.:

Revision N 0.: 1

April 1999

Approved for public release; further dissemination is unlimited.

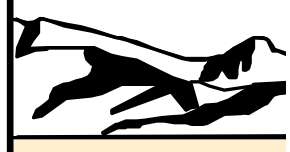

Environm ental Restoration

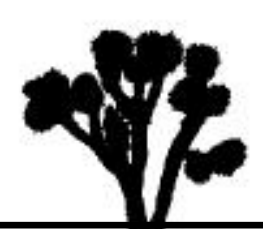

Division 


\title{
CORRECTIVE ACTION DECISION DOCUMENT FOR CORRECTIVE ACTION UNIT 417: CENTRAL NEVADA TEST AREA SURFACE, NEVADA
}

\author{
DOE Nevada Operations Office
}

Las Vegas, Nevada

Controlled Copy No.:

Revision No.: 1

Approved for public release; further dissemination unlimited.

April 1999 
Available to the public from -

U.S. Department of Commerce

National Technical Information Service

5285 Port Royal Road

Springfield, VA 22161

(703) 487-4650

Available electronically at http://www.doe.gov/bridge. Available to

U.S. Department of Energy and its contractors in paper from -

U.S. Department of Energy

Office of Scientific and Technical Information

P.O. Box 62

Oak Ridge, TN 37831-0062

(423) 576-8401

Reference herein to any specific commercial product, process, or service by trade name, trademark, manufacturer, or otherwise, does not necessarily constitute or imply its endorsement, recommendation, or favoring by the United States Government or any agency thereof or its contractors or subcontractors 


\title{
CORRECTIVE ACTION DECISION DOCUMENT \\ FOR CORRECTIVE ACTION UNIT 417: \\ CENTRAL NEVADA TEST AREA SURFACE, NEVADA
}

\author{
Signature Approved \\ Approved by: \\ Monica L. Sanchez, Project Manager \\ Off-Sites Project \\ Date: $\quad$ 4/2/99
}

Approved by: $\frac{\text { Signature Approved }}{\text { Runore C. Wycoff, Project Manager }} \begin{aligned} & \text { Nevada Environmental Restoration Division } \\ & \text { Date: }\end{aligned}$ 


\section{Table of Contents}

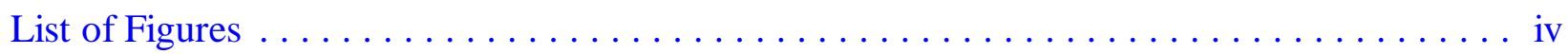

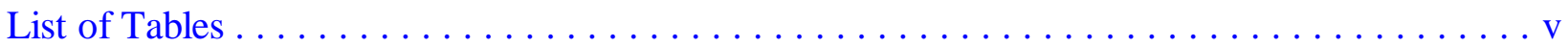

List of Acronyms and Abbreviations $\ldots \ldots \ldots \ldots \ldots \ldots \ldots \ldots \ldots \ldots \ldots \ldots \ldots \ldots \ldots$

Executive Summary $\ldots \ldots \ldots \ldots \ldots \ldots \ldots \ldots \ldots \ldots \ldots \ldots \ldots \ldots \ldots \ldots \ldots$

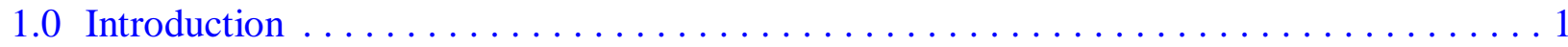

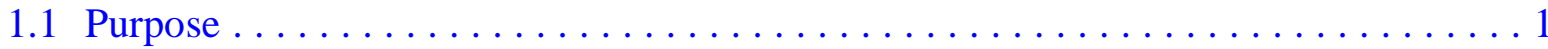

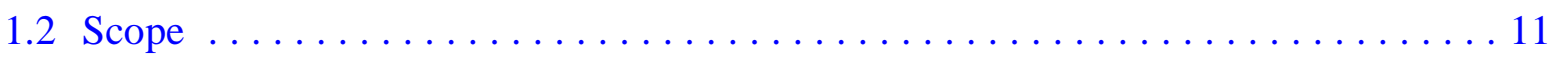

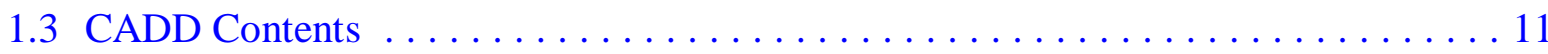

2.0 Corrective Action Investigation Summary $\ldots \ldots \ldots \ldots \ldots \ldots \ldots \ldots \ldots \ldots \ldots \ldots$

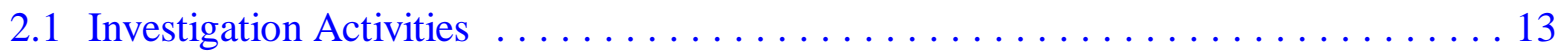

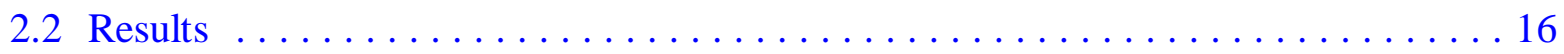

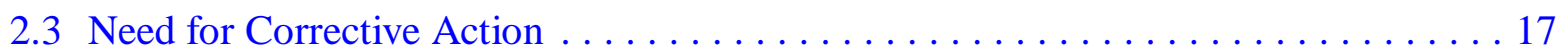

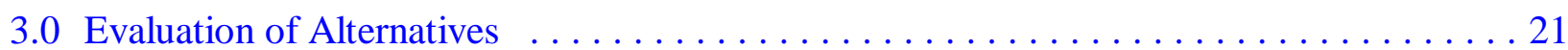

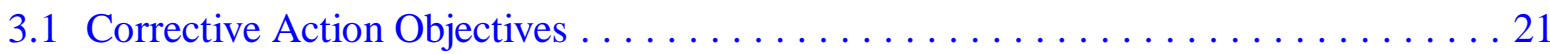

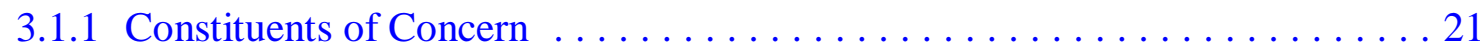

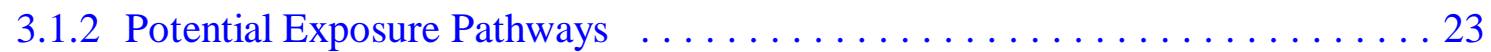

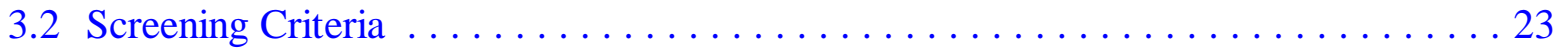

3.2.1 Corrective Action Standards . . . . . . . . . . . . . . . . . . 24

3.2.1.1 Protection of Human Health and the Environment . . . . . . . . . . . 24

3.2.1.2 Compliance with Media Cleanup Standards . . . . . . . . . . . . . . . 24

3.2.1.3 Control the Source(s) of the Release . . . . . . . . . . . . . . 24

3.2.1.4 Comply with Applicable Federal, State, and Local Standards for

Waste Management .................... 25

3.2.2 Remedy Selection Decision Factors . . . . . . . . . . . . . . 25

3.2.2.1 Short-Term Reliability and Effectiveness . . . . . . . . . . . 25

3.2.2.2 Reduction of Toxicity, Mobility, and/or Volume ............ 25 
3.2.2.3 Long-Term Reliability and Effectiveness . . . . . . . . . . . . . 26

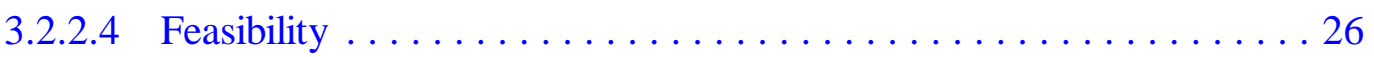

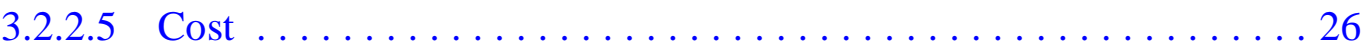

3.3 Development of Corrective Action Alternatives . . . . . . . . . . . . 27

3.3 .1 Alternative 1 - No Action . . . . . . . . . . . . . . . 28

3.3.2 Alternative 2 - Administrative Controls . . . . . . . . . . . . . 28

3.3.2.1 Close in Place With Site Posting . . . . . . . . . . . . . . . . . . . 29

3.3.2.2 Partial Excavation With Engineered Backfill . . . . . . . . . . . . . . 29

3.3.2.3 Construction of Engineered Cover . . . . . . . . . . . . . . . . . . . . 29

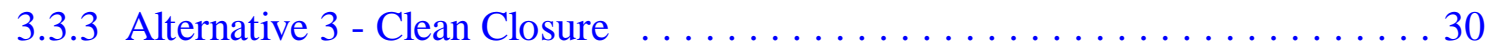

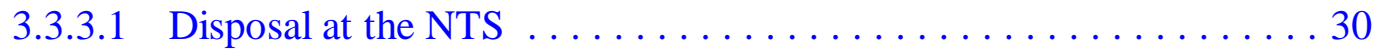

3.3.3.2 Disposal at the UC-1 Central Mud Pit . . . . . . . . . . . 30

3.3.3.3 Disposal at a Private Facility . . . . . . . . . . . . . . . 30

3.3.4 Alternative 4 - Bioremediation $\ldots \ldots \ldots \ldots \ldots \ldots \ldots \ldots \ldots \ldots \ldots \ldots \ldots \ldots \ldots \ldots$

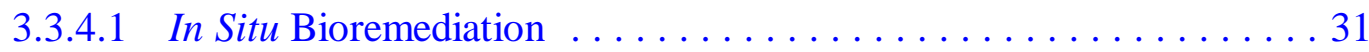

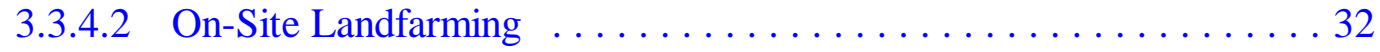

3.4 Evaluation and Comparison of Alternatives $\ldots \ldots \ldots \ldots \ldots \ldots \ldots \ldots \ldots \ldots \ldots \ldots \ldots$

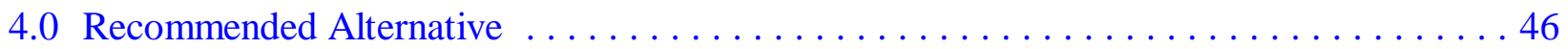

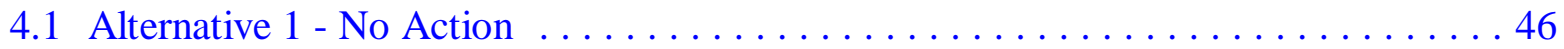

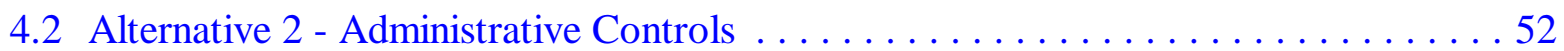

4.2 .1 Site Posting . . . . . . . . . . . . . . . . 52

4.2.2 Partial Excavation and Engineered Backfill ............... 53

4.2 .3 Engineered Cover . . . . . . . . . . . . . . . . . 53

4.3 Alternative 3 - Clean Closure with Disposal at UC-1 Central Mud Pit . . . . . . . . 54

4.4 Alternative 4 - Bioremediation . . . . . . . . . . . . . . . . . . . . . . 54

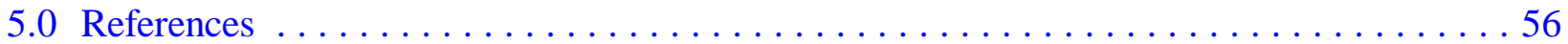

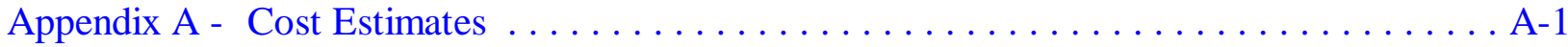

Appendix B - Evaluation of Risk $\ldots \ldots \ldots \ldots \ldots \ldots \ldots \ldots \ldots \ldots \ldots \ldots \ldots \ldots \ldots \ldots$ 
Table of Contents (Continued)

Page iii of vi

Appendix C - Comparative Evaluation of Alternatives $\ldots \ldots \ldots \ldots \ldots \ldots \ldots \ldots \ldots$

Appendix D - Corrective Action Investigation Report for Central Nevada Test Area, CAU 417 (Under Separate Cover) . . . . . . . . . . . . . . . . D-1 


\section{List of Figures}

Number

Title

Page

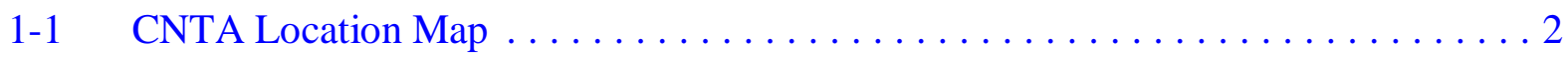

1-2 Central Nevada Test Area Land Withdrawal Map, Nye County, Nevada . . . . . . . . 3

1-3 UC-1 Area Map Showing CAS Locations $\ldots \ldots \ldots \ldots \ldots \ldots \ldots$

1-4 Central Mud Pit Map Showing CAS Locations .................... 7

1-5 UC-3 Area Map Showing CAS Locations $\ldots \ldots \ldots \ldots \ldots \ldots \ldots$

1-6 UC-3 Recording Trailer Park Map Showing Corrective Action Locations . . . . . . . . 9

1-7 UC-4 Area Map Showing CAS Locations $\ldots \ldots \ldots \ldots \ldots \ldots \ldots \ldots \ldots \ldots$ 


\section{List of Tables}

Number

Title

Page

ES-1 Proposed Remedial Alternatives $\ldots \ldots \ldots \ldots \ldots \ldots \ldots \ldots \ldots \ldots \ldots$. . . . . . . .

1-1 List of Corrective Action Sites $\ldots \ldots \ldots \ldots \ldots \ldots \ldots \ldots \ldots \ldots \ldots \ldots$

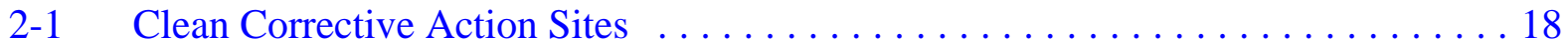

2-2 Contaminated Corrective Action Sites $\ldots \ldots \ldots \ldots \ldots \ldots \ldots \ldots \ldots \ldots \ldots \ldots \ldots \ldots$

3-1 Detailed Closure Standards Evaluation of Alternatives for CASs Exceeding Action Levels . . . . . . . . . . . . . . . . . . . . . . . . . . . . . . . . . 33

3-2 Detailed Remedy Selection Decision Factors Evaluation of Alternatives for CASs Exceeding Action Levels $\ldots \ldots \ldots \ldots \ldots \ldots \ldots \ldots . \ldots . \ldots . \ldots 35$

3-3 Comparative Evaluation of Corrective Action Alternatives for Sites Exceeding Action Levels . . . . . . . . . . . . . . . . . . . . . . . . . . . . 38

4-1 Proposed Remedial Alternatives $\ldots \ldots \ldots \ldots \ldots \ldots \ldots \ldots \ldots \ldots \ldots \ldots$

A-1 CAU 417 CNTA Surface CADD Alternatives - Cost Summary . ........... A-2

C-1 Comparative Evaluation of Alternatives $\ldots \ldots \ldots \ldots \ldots \ldots \ldots \ldots \ldots \ldots \ldots \ldots \ldots$ 


\section{List of Acronyms and Abbreviations}

CADD Corrective Action Decision Document

CAIP Corrective Action Investigation Plan

CAP Corrective Action Plan

CAS Corrective Action Site(s)

CAU Corrective Action Unit

CFR Code of Federal Regulations

$\mathrm{cm} \quad$ Centimeter(s)

CMP Central Mud Pit

CNTA Central Nevada Test Area

COC Constituent(s) of concern

DOE/NV U.S. Department of Energy, Nevada Operations Office

EPA U.S. Environmental Protection Agency

FFACO Federal Facilities Agreement and Consent Order

$\mathrm{ft} \quad$ Foot (feet)

in. $\quad \operatorname{Inch}(\mathrm{es})$

$\mathrm{km} \quad$ Kilometer(s)

$\mathrm{km}^{2} \quad$ Square kilometer(s)

m Meter(s)

$\mathrm{m}^{3} \quad$ Cubic meter(s)

$\mathrm{mg} / \mathrm{kg} \quad$ Milligram(s) per kilogram

mi Mile(s)

$\mathrm{mi}^{2} \quad$ Square mile(s)

NAC Nevada Administrative Code

NDEP Nevada Division of Environmental Protection

NRS Nevada Revised Statutes

NTS Nevada Test Site

PAH Polycyclic aromatic hydrocarbons

PAL Preliminary action level(s)

RCRA Resource Conservation and Recovery Act

SVOC Semivolatile organic compounds

TPH Total petroleum hydrocarbons

UST Underground storage $\operatorname{tank}(\mathrm{s})$

$\mathrm{yd}^{3} \quad$ Cubic yard(s) 


\section{Executive Summary}

This Corrective Action Decision Document (CADD) has been prepared for the Central Nevada Test Area Surface (Corrective Action Unit [CAU] 417) in accordance with the Federal Facility Agreement and Consent Order of 1996.

Corrective Action Unit 417 is located in Hot Creek Valley in Nye County, Nevada, and consists of three separate land withdrawal areas, UC-1, UC-3, and UC-4. There are 34 corrective action sites (CASs) on the site including two underground storage tanks, five septic systems, eight shaker pad/cuttings disposal areas, one decontamination facility pit, one burn area, one scrap/trash dump, one outlier area (adjacent to but outside a mud pit), eight housekeeping sites, and 16 mud pits (divided between seven CASs).

The purpose of this CADD is to identify and provide a rationale for the selection of a recommended corrective action alternative for each CAS.

The scope of this CADD consists of the following:

- Develop corrective action objectives.

- Identify corrective action alternative screening criteria.

- Develop corrective action alternatives.

- Perform detailed and comparative evaluations of the corrective action alternatives in relation to the corrective action objectives and screening criteria.

- Recommend the preferred corrective action alternative for each CAS.

Between September 1996 and June 1998, four field events were conducted to complete a corrective action investigation in accordance with the Corrective Action Investigation Plan for Central Nevada Test Area, CAU No. 417 (DOE/NV, 1997) and Addendum to the Corrective Action Investigation Plan for Central Nevada Test Area, CAU No. 417 (DOE/NV, 1998). Details of these activities can be found in Appendix D of this document. The results of the investigation indicated the only contaminant of concern was total petroleum hydrocarbon which was found in 18 of the CASs above the State Action Level of 100 milligrams per kilogram $(\mathrm{mg} / \mathrm{kg})$. 
Based on the potential exposure pathways, the following corrective action objectives have been identified for CAU 417:

- Prevent or mitigate human exposure to contaminated surface and subsurface soils and drilling debris.

- Remediate the site per applicable state and federal regulations (NAC, 1996b).

Based on the review of existing data and current and future land use, the following alternatives were developed for consideration at CAU 417:

- Alternative 1 - No Action

- Alternative 2 - Administrative Controls

- Alternative 3 - Clean Closure

- Alternative 4 - Bioremediation

The corrective action alternatives were evaluated based on four general corrective action standards and five remedy-selection decision factors. Based on the results of this evaluation, proposed alternatives were selected for each CAS as indicated in Table ES-1. Alternative 4 is not included on the table as none of the sites fell into this category.

The proposed corrective action alternatives were selected on their technical merits, focusing on performance, reliability, feasibility, and safety. The alternatives were judged to meet all requirements for the technical components evaluated. These alternatives meet all applicable state and federal regulations for closure of the sites and will reduce future exposure pathways into the contents of the sites. During corrective action implementation, these alternatives will present minimal potential threat to site workers in contact with the waste. However, procedures will be developed and implemented to ensure worker health and safety. 
Table ES-1

\section{Proposed Remedial Alternatives}

(Page 1 of 2)

\begin{tabular}{|c|c|c|c|c|}
\hline \multirow{2}{*}{$\begin{array}{l}\text { Corrective } \\
\text { Action Site }\end{array}$} & \multirow{2}{*}{$\begin{array}{l}\text { Alternative } 1 \\
\text { No Action }\end{array}$} & \multicolumn{2}{|c|}{$\begin{array}{c}\text { Alternative } 2 \\
\text { Administrative Controls } \\
\end{array}$} & \multirow{2}{*}{$\begin{array}{c}\begin{array}{c}\text { Alternative } 3 \\
\text { Clean Closure } \\
\text { Disposal at } \\
\text { UC-1 CMP }\end{array} \\
\end{array}$} \\
\hline & & Site Posting & $\begin{array}{c}\text { Engineered } \\
\text { Cover }\end{array}$ & \\
\hline \multicolumn{5}{|l|}{ UC-1 Area } \\
\hline 58-05-01 - Septic System & $x$ & & & \\
\hline $\begin{array}{l}\text { 58-07-01 - Decon Facility Pit } \\
(\text { SAME AS 58-35-01) }\end{array}$ & $x$ & & & \\
\hline 58-09-01 - Central Mud Pit & & & $x$ & \\
\hline 58-09-02 - Mud Pit U1A & & $x$ & & \\
\hline 58-09-04 - Mud Pit U1B & $x$ & & & \\
\hline $\begin{array}{l}\text { 58-09-05 - Mud Pit } \\
\text { U1C/Equipment \& Staging Areas }\end{array}$ & $x$ & & & \\
\hline $\begin{array}{l}\text { 58-09-05 - Mud Pit } \\
\text { U1D/Equipment and Staging } \\
\text { Areas }\end{array}$ & $x$ & & & \\
\hline 58-09-05 - Mud Pit U1E & & $x$ & & \\
\hline 58-10-03 - Shaker Pad Area (U1S) & & & & $x$ \\
\hline $\begin{array}{l}58-35-01 \text { - Burn Area (SAME AS } \\
58-07-01)^{b}\end{array}$ & $x$ & & & \\
\hline $\begin{array}{l}\text { 58-44-01 - Drilling Mud/Grout } \\
\text { Piles } \\
\text { UC-1 Area X Northeast }\end{array}$ & $x$ & & & \\
\hline $\begin{array}{l}\text { 58-44-02 - Drilling Mud/Grout } \\
\text { Piles } \\
\text { UC-1 Area X Southwest }\end{array}$ & $x$ & & & \\
\hline 58-44-05 - Grout Pile & $x$ & & & \\
\hline 58-44-06 - Grout Pile U1Y & & $x$ & & \\
\hline \multicolumn{5}{|l|}{ UC-3 Area } \\
\hline 58-05-02 - Septic System & $x$ & & & \\
\hline $\begin{array}{l}\text { 58-05-03 - Recording Trailer Park } \\
\text { UST }\end{array}$ & $x$ & & & \\
\hline 58-05-05 - Septic System & $x$ & & & \\
\hline $\begin{array}{l}\text { 58-05-06 - Recording Trailer Park } \\
\text { Septic Tank old=septic system }\end{array}$ & $x$ & & & \\
\hline 58-09-06 - Mud Pit U3A & $\mathrm{X}$ & & & \\
\hline 58-09-06 - Mud Pit U3B & $x$ & & & \\
\hline 58-09-06 - Mud Pit U3C & $x$ & & & \\
\hline 58-09-06 - Mud Pit U3D & $x$ & & & \\
\hline 58-09-06 - Mud Pit U3E & & $x$ & & \\
\hline
\end{tabular}


Table ES-1

\section{Proposed Remedial Alternatives}

(Page 2 of 2)

\begin{tabular}{|c|c|c|c|c|}
\hline \multirow{2}{*}{$\begin{array}{l}\text { Corrective } \\
\text { Action Site }\end{array}$} & \multirow{2}{*}{$\begin{array}{l}\text { Alternative } 1 \\
\text { No Action }\end{array}$} & \multicolumn{2}{|c|}{$\begin{array}{c}\text { Alternative } 2 \\
\text { Administrative Controls }\end{array}$} & \multirow{2}{*}{$\begin{array}{c}\begin{array}{c}\text { Alternative } 3 \\
\text { Clean Closure }\end{array} \\
\text { Disposal at } \\
\text { UC-1 CMP }\end{array}$} \\
\hline & & Site Posting & $\begin{array}{c}\text { Engineered } \\
\text { Cover }\end{array}$ & \\
\hline 58-10-01 - Shaker Pad Area (U3S) & & $x$ & & \\
\hline $\begin{array}{l}\text { 58-10-06 - Drill Mud/Cuttings } \\
\text { (U3X) }\end{array}$ & $\mathrm{x}$ & & & \\
\hline 58-19-01 - Scrap \& Trash Dump & $x$ & & & \\
\hline $\begin{array}{l}\text { 58-25-01 - Spill Southern Outlier } \\
\text { (U3E) }\end{array}$ & & $\mathrm{x}$ & & \\
\hline 58-35-02 - Burn Area & $x$ & & & \\
\hline $\begin{array}{l}\text { 58-44-03 - Drill Mud/Grout Spill } \\
\text { Area (U3Z) }\end{array}$ & & & & $x$ \\
\hline $\begin{array}{l}\text { 58-44-04 - Drill Mud/Grout Spill } \\
\text { Area (U3Y) }\end{array}$ & $x$ & & & \\
\hline 58-98-01 - Waste Pile & $x$ & & & \\
\hline 58-98-02 - Waste Pile & $x$ & & & \\
\hline 58-98-03 - Waste Pile & $x$ & & & \\
\hline 58-98-04 - Waste Pile & $\mathrm{x}$ & & & \\
\hline $\begin{array}{l}\text { 58-99-01 - UC3 UST } \\
\text { old=protruding pipes }\end{array}$ & $x$ & & & \\
\hline \multicolumn{5}{|l|}{ UC-4 Area } \\
\hline 58-05-04 - Septic System & $x$ & & & \\
\hline 58-09-03 - Mud Pit U4A & & $x$ & & \\
\hline 58-09-03 - Mud Pit U4B & & $x$ & & \\
\hline 58-09-03 - Mud Pit U4C & & & $\mathrm{X}$ & \\
\hline 58-09-03 - Mud Pit U4D & & $x$ & & \\
\hline 58-09-03 - Mud Pit U4E & $x$ & & & \\
\hline 58-10-02 - Shaker Pad Area (U4S) & & & & $x$ \\
\hline $\begin{array}{l}\text { 58-10-04 - Shaker Pad Area } \\
(\mathrm{U} 4 \mathrm{~W})\end{array}$ & & & & $\mathrm{x}$ \\
\hline 58-10-05 - Shaker Pad Area (U4X) & & $x$ & & \\
\hline $\begin{array}{l}\text { Not Assigned - Scrap \& Trash } \\
\text { Dump (east of UC-4 SGZ) }\end{array}$ & $x$ & & & \\
\hline
\end{tabular}

${ }_{b}^{a}$ CMP - Central Mud Pit at UC-1

The decon facility pit and "burn area" were originally identified as two separate sites. However, it was later determined that what was thought to be the burned material was actually part of the asphalt-covered decon pit liner. 


\subsection{Introduction}

This corrective Action Decision Document (CADD) has been prepared for the Central Nevada Test Area (CNTA) Surface (Corrective Action Unit [CAU] 417) in accordance with the Federal Facility Agreement and Consent Order (FFACO) of 1996 that was agreed to by the U.S. Department of Energy, Nevada Operations Office (DOE/NV), the Nevada Division of Environmental Protection (NDEP), and the U.S. Department of Defense (FFACO, 1996). Discussions between DOE/NV, Bureau of Land Management, U.S. Forest Service, and interested citizens groups are occurring in regards to the final disposition of this land. The CADD provides or references the specific information necessary to evaluate possible corrective action alternatives for the Corrective Action Sites (CASs) within CAU 417 and to select the proposed alternative.

Corrective Action Unit 417 is located in Hot Creek Valley in Nye County, Nevada, about 105 kilometers $(\mathrm{km})$ (65 miles [mi]) northeast of Tonopah (Figure 1-1). The CNTA consists of three separate land withdrawal areas (Figure 1-2). The central one (UC-1) covers 2.6 square kilometers $\left(\mathrm{km}^{2}\right)\left(1\right.$ square mile $\left.\left[\mathrm{mi}^{2}\right]\right)$ and the other two (UC-3 and UC-4) cover $2.9 \mathrm{~km}^{2}$ (1.5 $\left.\mathrm{mi}^{2}\right)$ each. UC-4 and UC-3 are located approximately $4 \mathrm{~km}(2.5 \mathrm{mi})$ north and south of UC-1, respectively. Corrective Action Unit 417 is comprised of two underground storage tanks, five septic systems, eight shaker pad/cuttings disposal areas, one decontamination facility pit, one burn area, one scrap/trash dump, one outlier area, eight housekeeping sites, and 16 mud pits.

The sites have been divided into six groups based on similarity of type of potential contamination present. The six groups are: underground storage tanks (UST), shaker pad/cutting disposal areas, mud pits, housekeeping sites, septic systems, and miscellaneous sites which groups the sites that do not fit in the other categories. The sites have been assigned CAS numbers as shown in Table 1-1.

\subsection{Purpose}

The purpose of this CADD is to identify and provide the rationale for the selection of a proposed corrective action alternative for each CAS or group of CASs. Identification of the alternatives to be considered will be based on process knowledge and the results of the corrective action investigation as described in the Corrective Action Investigation Plan for Central Nevada Test Area, CAU No. 417 (DOE/NV, 1997) and Addendum to the Corrective Action Investigation Plan for Central Nevada Test Area, CAU No. 417 (DOE/NV, 1998). 


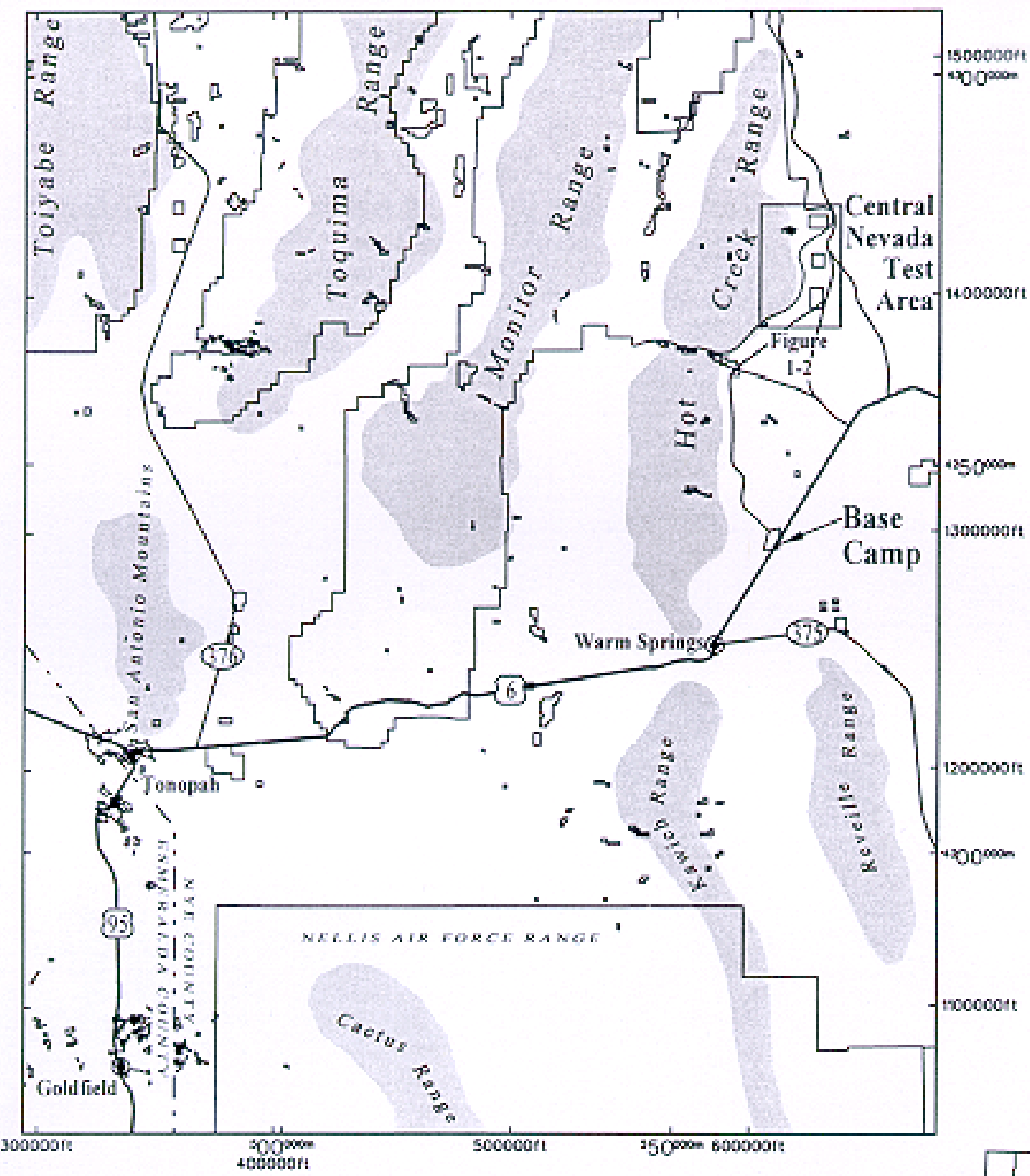

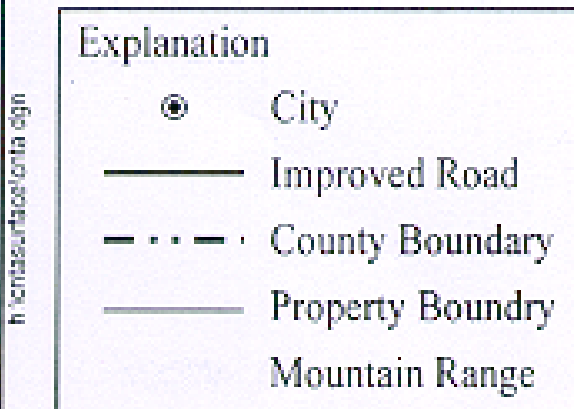

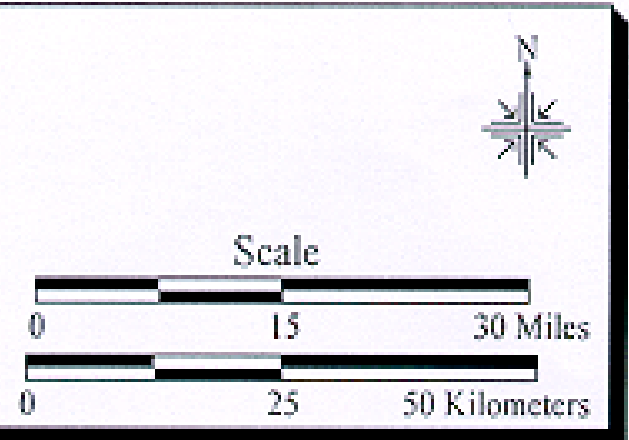

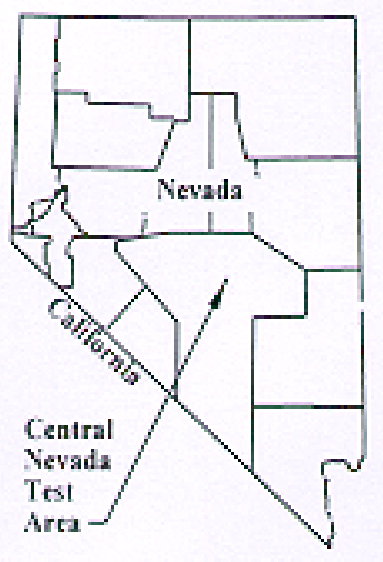

Source: U.S. BLM Surface Management Status Map, 1990 

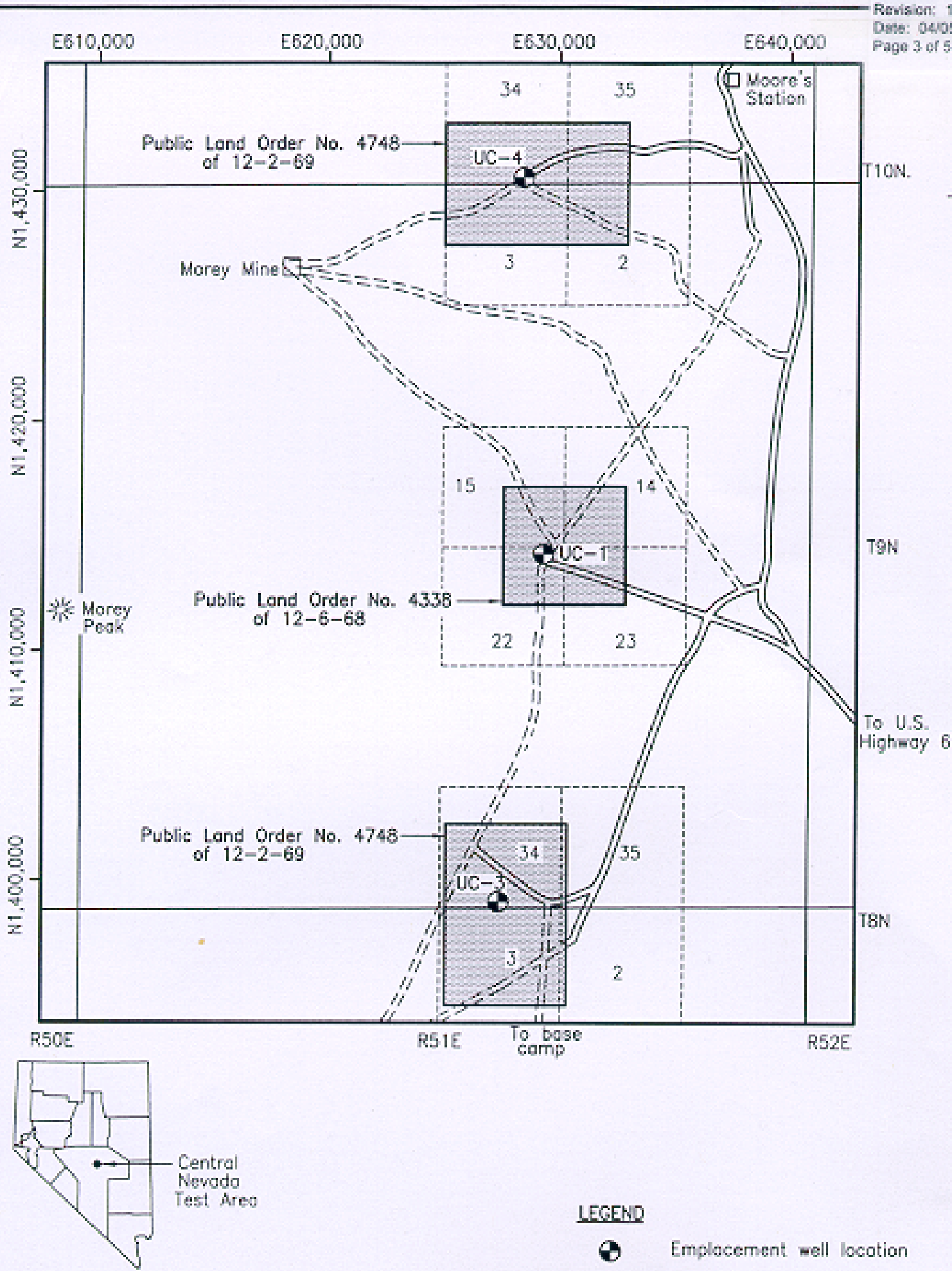

SCALE

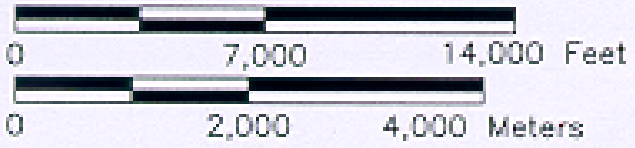

Source: AEC, 1973

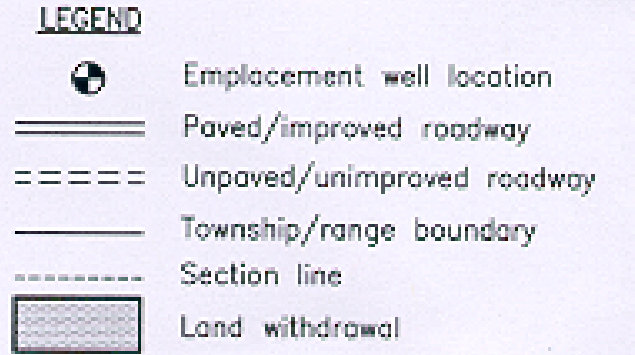

Figure 1-2

Central Nevada Test Area Land Withdrawal Map, Nye County, Nevada 
Table 1-1

\section{List of Corrective Action Sites}

(Page 1 of 2)

\begin{tabular}{|c|c|c|c|}
\hline CAS \# & Location & Description & Group \\
\hline \multicolumn{4}{|c|}{ UC-1 Sites (includes Central Mud Pit area [Figures 1-3 and 1-4]) } \\
\hline $58-05-01$ & West of the Central Mud Pit & $\begin{array}{l}\text { Support trailer park septic } \\
\text { system }\end{array}$ & Septic system \\
\hline $58-10-03$ & East of UC-1 & Shaker pad area & $\begin{array}{l}\text { Shaker pad/cuttings } \\
\text { disposal area }\end{array}$ \\
\hline $58-07-01$ & \multirow{2}{*}{$\begin{array}{l}\text { West of the Central Mud Pit - these are } \\
\text { the same location, } 58-35-01 \text { was } \\
\text { originally misidentified as a burn pit }\end{array}$} & \multirow[t]{2}{*}{ Decon facility pit } & \multirow[t]{2}{*}{ Miscellaneous sites } \\
\hline $58-35-01$ & & & \\
\hline $58-44-01$ & West of the Central Mud Pit & Drilling mud/grout piles (2) & Housekeeping site \\
\hline $58-44-02$ & Southeast of UC-1 & Drilling mud/grout piles (2) & Housekeeping site \\
\hline $58-44-05$ & Northeast of UC-1 (not on figure) & Grout pile & Housekeeping site \\
\hline $58-44-06$ & $\begin{array}{l}\text { South of UC-1 recording trailer park } \\
\text { (not on figure) }\end{array}$ & Grout pile & Housekeeping site \\
\hline $58-98-03$ & $\begin{array}{l}\text { Southwest of the Central Mud Pit (not } \\
\text { on figure) }\end{array}$ & $\begin{array}{l}\text { Waste pile (drums, filters } \\
\text { etc.) }\end{array}$ & Housekeeping site \\
\hline $58-09-01$ & East of UC-1 & Central Mud Pit & Mud pit \\
\hline $58-09-02$ & Southwest of the Central Mud Pit & UC-1 Mud Pit A & Mud pit \\
\hline $58-09-04$ & At HTH-1 Well (not on figure) & Mud pit/borrow area & Mud pit \\
\hline $58-09-05$ & At UC-1 Surface GZ & UC-1 Mud Pits C, D, E & Mud pit \\
\hline \multicolumn{4}{|c|}{ UC-3 Sites (includes the Recording Trailer Park [Figures 1-5 and 1-6]) } \\
\hline $58-99-01$ & Southeast of UC-3 & UST (projecting pipes) & UST \\
\hline $58-05-03$ & At the UC-3 recording trailer park & UST & UST \\
\hline $58-05-02$ & Support trailer park east of UC-3 & $\begin{array}{l}\text { Support trailer park septic } \\
\text { system }\end{array}$ & Septic system \\
\hline $58-05-05$ & Southeast of UC-3 & Septic tank & Septic system \\
\hline $58-05-06$ & At the UC-3 recording trailer park & Septic tank & Septic system \\
\hline $58-10-01$ & Northeast of UC-3 & $\begin{array}{l}\text { Shaker pad area (drill } \\
\text { cuttings debris) }\end{array}$ & $\begin{array}{l}\text { Shaker pad/cuttings } \\
\text { disposal area }\end{array}$ \\
\hline $58-10-06$ & North of UC-3 & $\begin{array}{l}\text { Drilling mud and cuttings UC- } \\
3 \text { Area } X\end{array}$ & $\begin{array}{l}\text { Shaker pad/cuttings } \\
\text { disposal area }\end{array}$ \\
\hline $58-44-03$ & Southeast of UC-3 & $\begin{array}{l}\text { Drill mud/grout spill area } \\
\text { UC-3 Area Z }\end{array}$ & $\begin{array}{l}\text { Shaker pad/cuttings } \\
\text { disposal area }\end{array}$ \\
\hline $58-44-04$ & Southwest of UC-3 & $\begin{array}{l}\text { Drill mud/grout spill area } \\
\text { UC-3 Area Y }\end{array}$ & $\begin{array}{l}\text { Shaker pad/cuttings } \\
\text { disposal area }\end{array}$ \\
\hline
\end{tabular}


Table 1-1

List of Corrective Action Sites

(Page 2 of 2)

\begin{tabular}{||l|l|l|l||}
\hline \multicolumn{1}{|c|}{ CAS \# } & \multicolumn{1}{|c|}{ Location } & \multicolumn{1}{|c|}{ Description } & \multicolumn{1}{|c||}{ Group } \\
\hline \hline $58-35-02$ & At the UC-3 recording trailer park & Burn area & Miscellaneous \\
\hline $58-19-01$ & $\begin{array}{l}\text { West of UC-3 recording trailer park } \\
\text { (not on figure) }\end{array}$ & Scrap and trash dump & Housekeeping \\
\hline $58-25-01$ & South of UC-3 mud pit E & $\begin{array}{l}\text { U3E southern outlier (spill } \\
\text { area) }\end{array}$ & Miscellaneous \\
\hline $58-98-01$ & West of UC-3 & $\begin{array}{l}\text { Waste pile (drums, filters, } \\
\text { etc.) }\end{array}$ & Housekeeping \\
\hline $58-98-02$ & South of UC-3 & $\begin{array}{l}\text { Waste pile (drums, filters, } \\
\text { etc.) }\end{array}$ & Housekeeping \\
\hline $58-98-04$ & Southeast of UC-3 (not on figure) & $\begin{array}{l}\text { Waste pile (metal, cable, } \\
\text { etc.) }\end{array}$ & Housekeeping \\
\hline $58-09-06$ & At UC-3 & UC-3 Mud Pits A, B, C, D, E & Mud pits \\
\hline $58-05-04$ & Support trailer park UC-4 & $\begin{array}{l}\text { Support trailer park septic } \\
\text { system }\end{array}$ & Septic system \\
\hline $58-10-02$ & North of UC-4 & $\begin{array}{l}\text { UC-4 Area S shaker pad } \\
\text { (drill cuttings debris) }\end{array}$ & $\begin{array}{l}\text { Shaker pad/cuttings } \\
\text { disposal area }\end{array}$ \\
\hline $58-10-04$ & Drainage south of UC-4 & $\begin{array}{l}\text { UC-4 Area W (drill cuttings } \\
\text { debris) }\end{array}$ & $\begin{array}{l}\text { Shaker pad/cuttings } \\
\text { disposal area }\end{array}$ \\
\hline $58-10-05$ & Drainage north and east of UC-4 & $\begin{array}{l}\text { UC-4 Area X (drill cuttings } \\
\text { debris) }\end{array}$ & $\begin{array}{l}\text { Shaker pad/cuttings } \\
\text { disposal area }\end{array}$ \\
\hline $58-09-03$ & At UC-4 & $\begin{array}{l}\text { UC-4 Mud Pits A, B, C, D, E } \\
\text { (Figure 1-7) }\end{array}$ \\
\hline
\end{tabular}




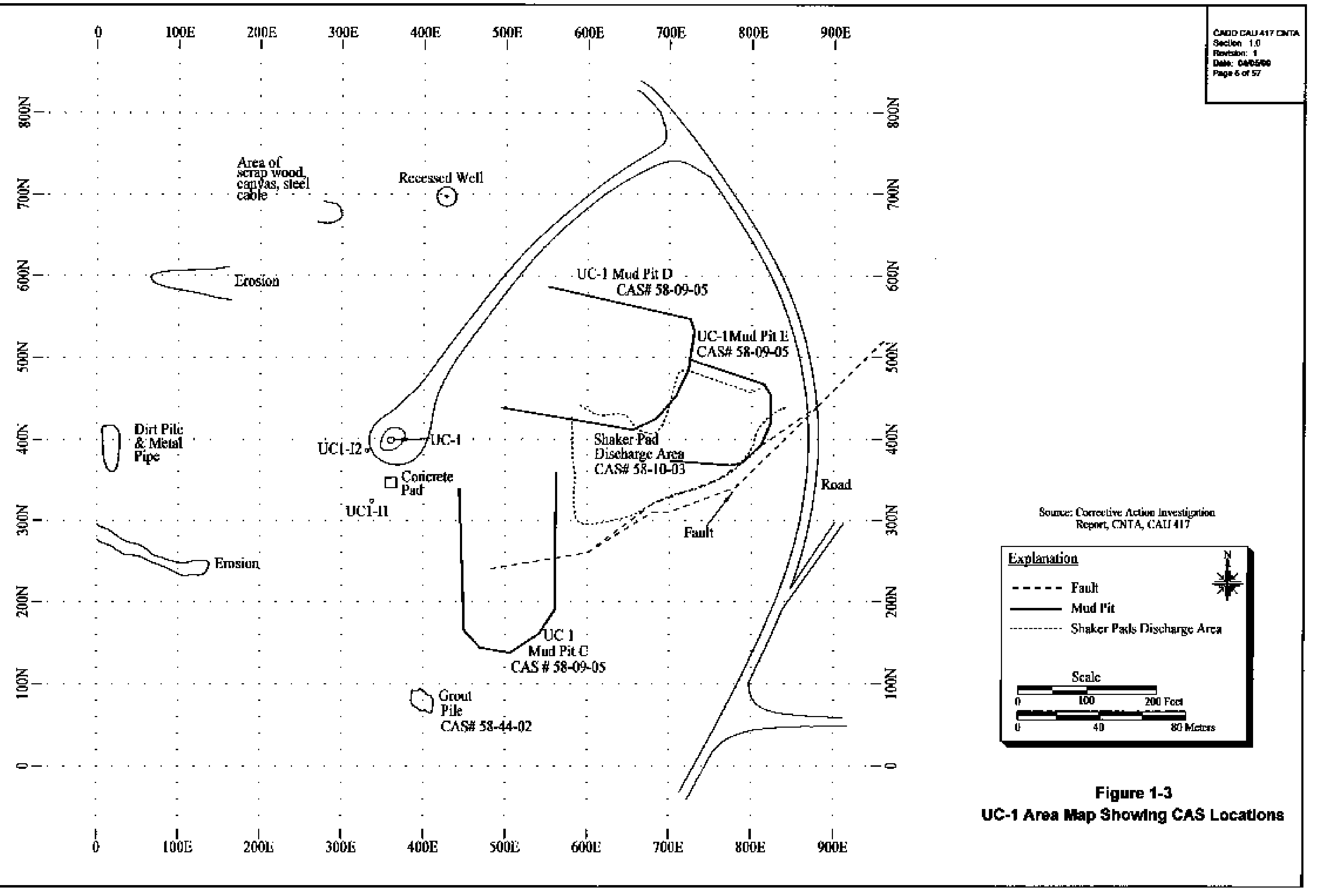




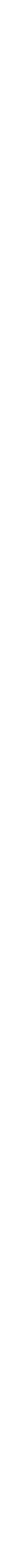




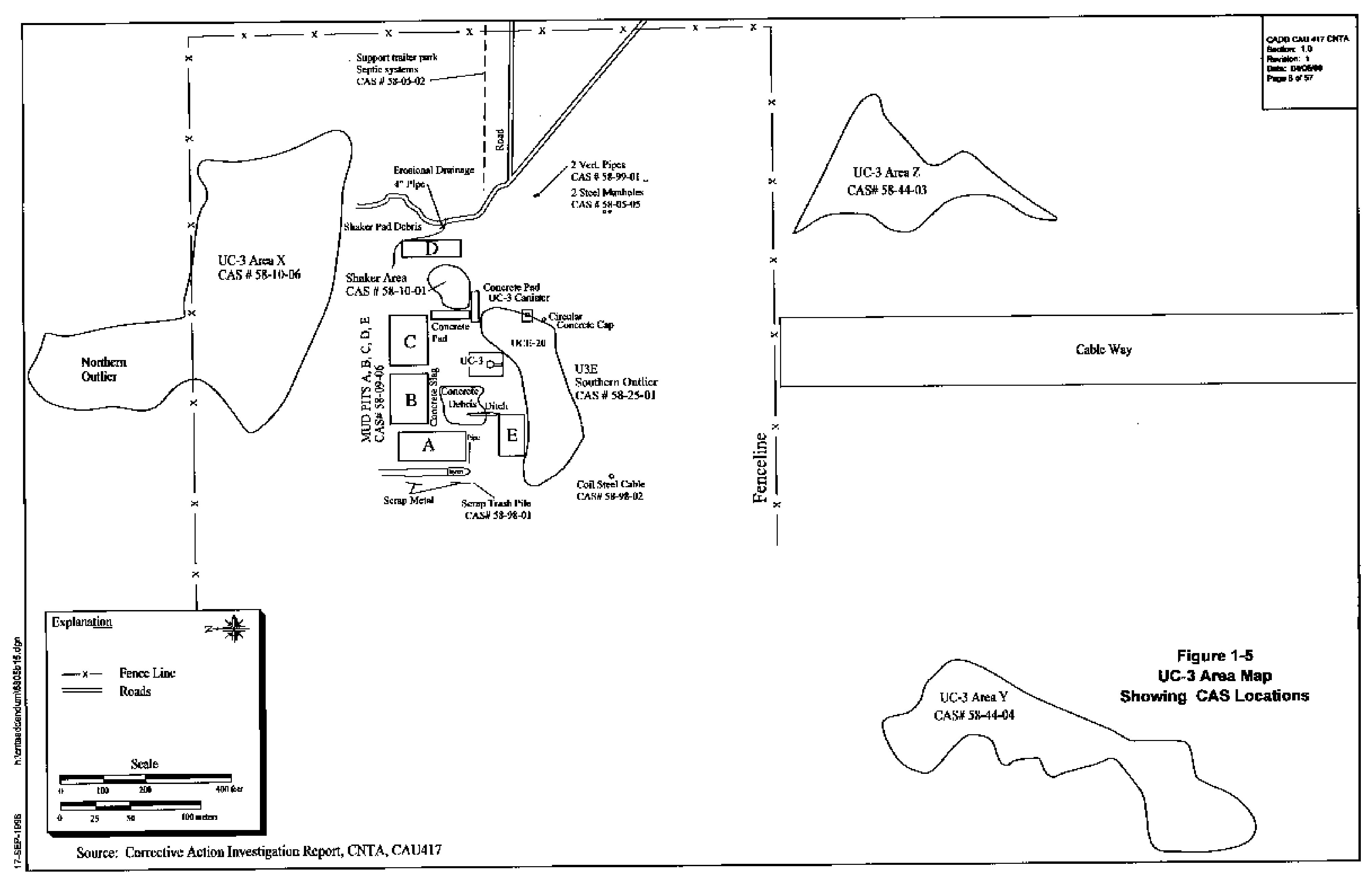


Revision: 1

Date: 04/05/99

Page 9 of 57

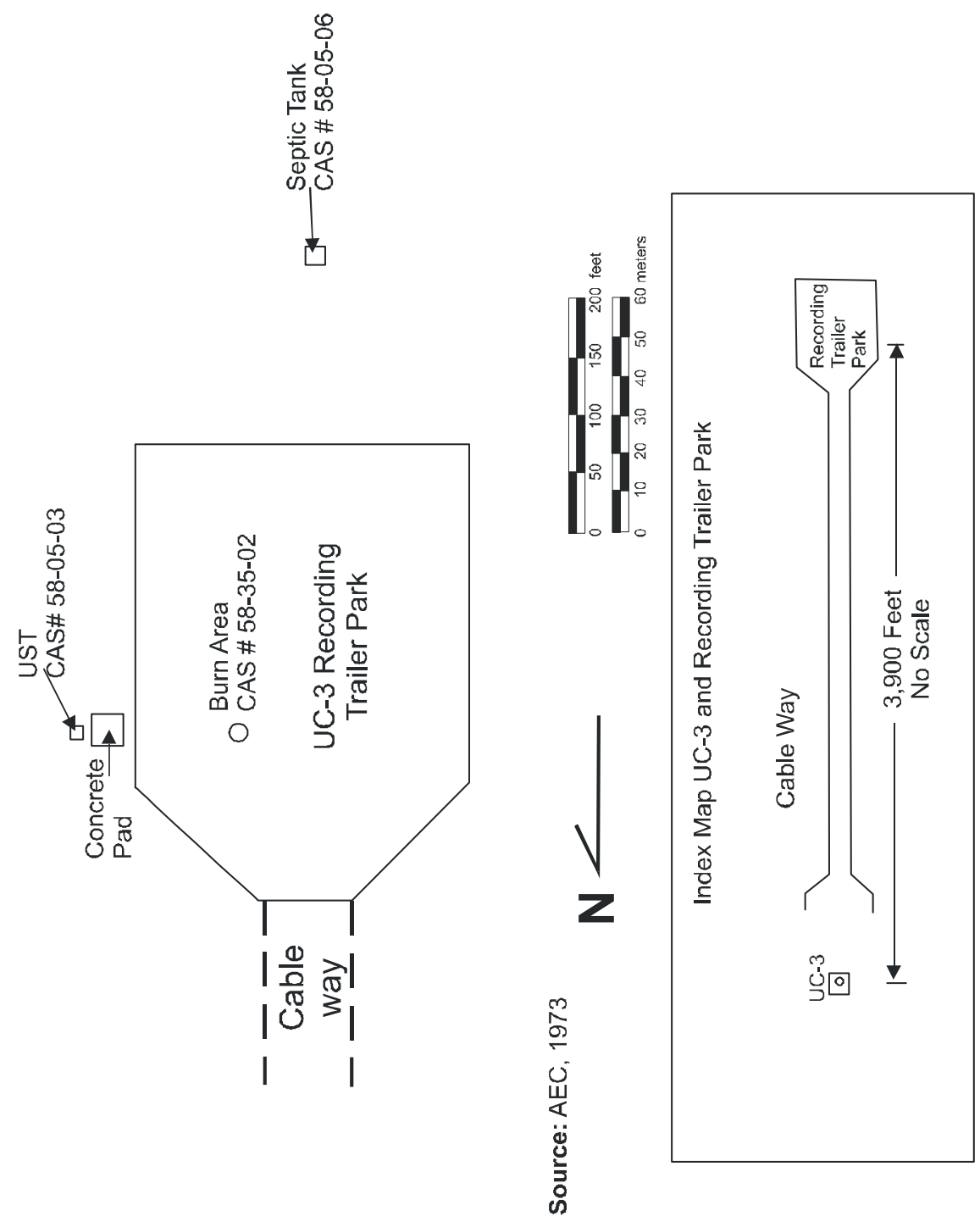

Figure 1-6 


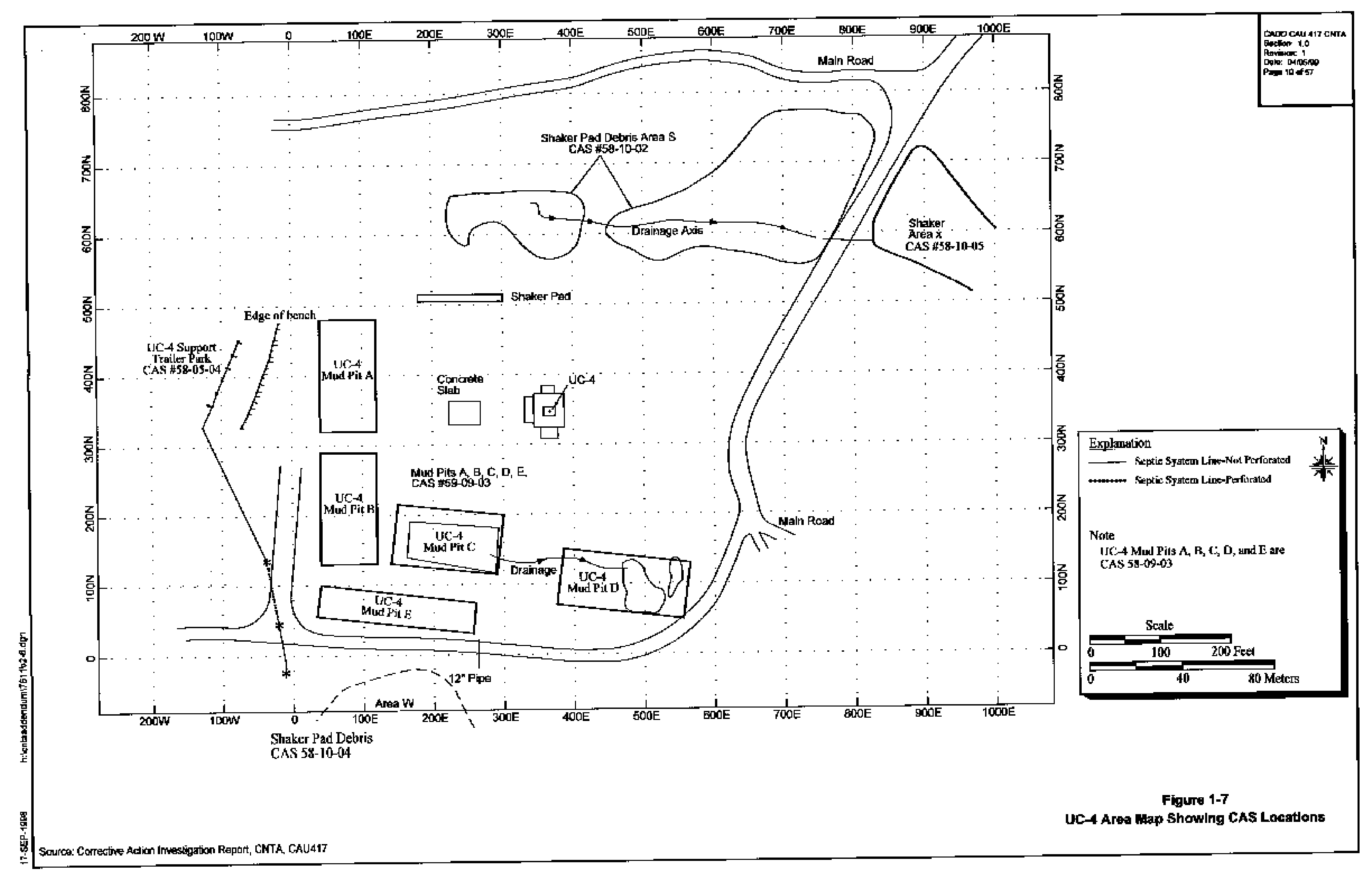


The general characteristics of CAU 417 as discussed in the Corrective Action Investigation Plan (CAIP) (DOE/NV, 1997) and the Addendum to the CAIP (DOE/NV, 1998) have not changed except as described in the following section. Based on results from samples collected as part of the corrective action investigation, the septic tanks at UC-3 and UC-3 recording trailer park were back filled and closed in place in accordance with Nevada Administrative Code (NAC) 444.818(10) (NAC, 1998). In addition the two USTs were excavated, removed from the site, and the excavations backfilled with clean soil from the site. These activities will be discussed further in Section 2.0, Corrective Action Investigation Summary, and the Corrective Action Investigation Report (Appendix D of this report).

\subsection{Scope}

The scope of this CADD consists of the identification, evaluation, and recommendation of a preferred corrective action alternative to be implemented at the CNTA. To achieve this scope, the following actions have been taken:

- Develop corrective action objectives.

- Identify corrective action alternative screening criteria.

- Develop corrective action alternatives.

- Perform detailed and comparative evaluations of the corrective action alternatives in relation to the corrective action objectives and screening criteria.

- Recommend and justify a preferred corrective action alternative for each CAS or group of CASs.

\subsection{CADD Contents}

This CADD has been divided into the following sections:

Section 1.0 - Introduction: summarizes the purpose, scope, and contents of this CADD

Section 2.0 - Corrective Action Investigation Summary: summarizes the investigation field activities, the results of the investigation, and the need for corrective action

Section 3.0 - Evaluation of Alternatives: documents the steps taken in determining a preferred corrective action alternative

Section 4.0 - Recommended Alternative: presents the preferred corrective action alternative and the rationale for its selection based on the corrective action objectives and alternative screening criteria. 
Section 5.0 - References: presents a list of all referenced documents.

Appendix A - Cost Estimates: presents the cost estimates for each alternative including construction, installation, operation, and maintenance costs.

Appendix B - Evaluation of Risk: because the only contaminant is total petroleum hydrocarbons (TPH) a risk assessment has not been completed. An A-K determination is presented instead to show that the contamination left on site does not pose a threat to human health or the environment.

Appendix C - Comparative Evaluation of Corrective Action Alternatives

Appendix D - Corrective Action Investigation Report for Central Nevada Test Area, CAU 417

All work was performed in accordance with the following documents:

- Corrective Action Investigation Plan for Central Nevada Test Area CAU No. 417 (DOE/NV, 1997)

- Addendum to the Corrective Action Investigation Plan for Central Nevada Test Area CAU No. 417 (DOE/NV, 1998)

- Industrial Sites Quality Assurance Project Plan (DOE/NV, 1996b)

- Nevada Environmental Restoration Health and Safety Plan (DOE/NV, 1994a)

- Nevada Environmental Restoration Project Management Plan (DOE/NV, 1994b)

- Federal Facility Agreement and Consent Order (FFACO, 1996) 


\subsection{Corrective Action Investigation Summary}

The following sections describe the corrective action investigation activities and provides a summary of the data collected. For detailed investigation activity descriptions and presentation of the results, refer to the Corrective Action Investigation Report (Appendix D).

A statistical approach, as defined in the CAIP, was used to determine which depth intervals or layers inside individual mud pits and shaker pad areas were above the action level at the 90 percent confidence level for either total TPH or hexavalent chromium. In general, six locations inside each mud pit were selected for sampling at 0.61-meter (m) (2-feet [ft]) depth intervals.

The statistical test described in detail in the CAIP gave two results: "n ${ }_{d}$ " the minimum number of samples required to make a statistically valid decision, and "A," the amount by which a given layer was above or below the PAL. This took into account the mean and the standard deviation of the measurements in the layer and the false positive/false negative rates allowed. The values used in the TPH test were total TPH (diesel + motor oil). The values used in the chromium test were hexavalent chromium, if available. If a hexavalent chromium value was not available, the total chromium value was used as a "worse case scenario" for hexavalent chromium. If both X-ray Fluorescence and Flame Ionization Atomic Absorption values for total chromium were available for a given sample, the higher of the two was used.

\subsection{Investigation Activities}

The corrective action investigation was conducted in four separate field efforts. The first two efforts, Phase 1 and Phase 2, were guided by the CAIP (DOE/NV, 1997). The first effort performed using expedited site characterization methods, was conducted in September 1996 and consisted of surface geophysical surveys. The second effort performed using expedited site characterization methods was conducted in May and June 1997 and consisted of additional surface geophysical surveys, direct-push geophysical surveys, and direct-push soil sampling. The second two efforts were guided by the Addendum to the CAIP (DOE/NV, 1998) which was developed because additional CASs were found on site. In April 1998, a sampling effort was conducted to characterize the contents of the septic tanks and the USTs, and to determine if there were any contaminants in the burn area. The fourth field effort was conducted in June 1998 and consisted of removing the USTs and collecting soil samples from below the tanks to confirm that all contaminated soil had been removed; closing the two septic tanks in place; trenching and 
collecting soil samples from beneath the septic lines; and collecting additional soil samples using a sonic drill rig in areas where the direct-push rig met with refusal during the 1997 event.

The corrective action investigation tasks conducted under the CAIP (DOE/NV, 1997) were:

- Land surveys with a global positioning system to establish sampling grids over all of the areas to be sampled.

- Surface geophysical surveys over all of the areas to be sampled. These surveys included:

- Electromagnetic surveys to determine the extent of the mud pits

- Direct current resistivity surveys to define the vertical stratification

- Magnetometer surveys to detect buried drums, tanks, pipes, etc.

- Subsurface geophysical surveys with a dipole conductivity probe to map the thickness of the drilling mud in the buried mud pits. Surveys were conducted at 97 locations to depths ranging from $1.1 \mathrm{~m}(3.5 \mathrm{ft})$ to $7.4 \mathrm{~m}(24.4 \mathrm{ft})$.

- Soil sample collection using a direct-push drill rig equipped with a split spoon core barrel. Samples were collected every $0.6 \mathrm{~m}(2 \mathrm{ft})$. The entire $0.6 \mathrm{~m}(2 \mathrm{ft})$ interval was homogenized prior to collecting the sample. A total of 203 direct-push borings were

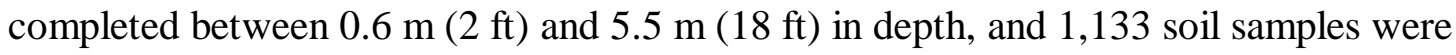
collected.

- Sample analysis using an on-site laboratory. Samples were analyzed for TPH/diesel, $\mathrm{TPH} /$ motor oil, and total chromium. The on-site laboratory analyzed 1,016 of the 1,133 samples collected; 105 were not analyzed based on the results of proximal samples, and 12 were sent to an off-site laboratory for waste determination analyses.

The corrective action investigation tasks conducted under the Addendum to the CAIP (DOE/NV, 1998) were:

- Sampled two USTs, two septic tanks, and a burn pit at the UC-3 recording trailer park to characterize the contents of the tanks and burn pit. Two liquid samples and 11 solid samples were collected. The samples were collected in April 1998 prior to the main field effort in June 1998. The sampling effort in April provided information that allowed the USTs and septic tanks to be closed during the June field work and determined that additional investigations were not needed at the burn pit.

- Soil sample collection using a sonic drill rig with a continuous core barrel. Samples were collected on the same sampling interval used for the direct-push method. Nine bore holes were drilled to depths between $3 \mathrm{~m}(10 \mathrm{ft})$ and $9.1 \mathrm{~m}(30 \mathrm{ft})$ and 70 soil samples were collected and sent to an off-site laboratory for analysis. 
- Used trenches and a downhole video camera to locate and map septic leach lines and leachfields. Soil samples were collected from under perforated leach lines and at outfalls to determine if any potentially hazardous materials were disposed of in the septic systems. Seventeen trenches were cut to depths up to $1.7 \mathrm{~m}(5.5 \mathrm{ft})$ and ten soil samples were collected to locate and characterize the septic systems.

- Based on analytical results from the April sampling, the contents of the septic tanks were removed by a local contractor and disposed of at a sewage treatment facility during the June 1998 field effort. The tanks were then backfilled with local material and closed in place.

- Based on analytical results from the April sampling, the contents of the USTs were removed, containerized, solidified, and shipped to a disposal facility on the Nevada Test Site (NTS) during the June 1998 field effort. After removal of the contents, the tanks were excavated and removed and soil samples were collected from below the tanks. Since there was obvious leakage from the tanks, both areas were over excavated. Samples were then collected from the bottom of the excavation, approximately $3.4 \mathrm{~m}(11 \mathrm{ft})$ below the ground surface. Twelve soil samples were collected to verify that the contaminated soils below the tanks had been removed. The excavated material was containerized and shipped to the NTS for disposal at the hydrocarbon landfill.

- Samples were analyzed for the following parameters:

- Septic tank characterization samples (both solid and liquid) and the trench samples were analyzed for total volatile organic compounds, semivolatile organic compounds (SVOC), Resource Conservation and Recovery Act (RCRA) metals, mercury, and $\mathrm{TPH} /$ diesel.

- UST characterization samples (both solid and liquid) and the UST soil excavation verification samples were analyzed for benzene, toluene, ethylbenzene, xylene; RCRA metals; mercury; and TPH/diesel.

- $\quad$ Burn pit characterization samples were analyzed for RCRA metals and mercury.

- Decontamination pit samples collected with the sonic drill rig were analyzed for SVOC, RCRA metals, mercury, TPH/diesel, and radionuclides through gamma spectrometry.

- U3E southern outlier samples collected with the sonic drill rig were analyzed for RCRA metals, mercury, and TPH/diesel.

Historical documents, interviews, and process knowledge were used to assist in the identification of potential contaminants of concern. A detailed description of the activities conducted is 
provided in the Central Nevada Test Area, CAU 417 Report and the Addendum to the Central Nevada Test Area, CAU 417, Corrective Action Investigation Report.

\subsection{Results}

The following is a summary of the corrective action investigation results:

- All reported concentrations of RCRA metals, including chromium in the mud pits, were below the preliminary action levels (PALs) established in the CAIP (DOE/NV, 1997).

- No radiological screening or gamma spectroscopy results were encountered above the PALs.

- Within the general areas (Central Mud Pit [CMP], UC-1, UC-3, and UC-4), 14 of the investigated CASs contained soils and/or drilling related materials with TPH diesel/motor oil concentrations that exceeded the PAL of 100 milligrams per kilogram $(\mathrm{mg} / \mathrm{kg})$.

- Two of the septic system sites (CAS No. 58-05-02 and CAS No. 58-05-04) had soils containing polycyclic aromatic hydrocarbon (PAH) concentrations that exceeded the U.S. Environmental Protection Agency (EPA) Region 9 Preliminary Remediation Goals (EPA, 1998) for industrial soils. However, subsequent sampling proved that the PAHs were from the material the septic lines were constructed of and were not the result of disposal of hydrocarbons in the septic systems. The analytical results substantiating this are presented in the Addendum to the Corrective Action Investigation Report.

- The decontamination facility pit (CAS No. 58-07-01) and the burn area (CAS No. 58-35-01) were determined to be the same site. The apparent burned material was determined to be the asphalt coated plastic liner material used to line the pit.

- The TPH contaminated areas ranged in thickness from $0.6 \mathrm{~m}(2 \mathrm{ft})$ to $6.1 \mathrm{~m}(20 \mathrm{ft})$ and the depth to the top of the contaminated zone varied from the surface to $1.8 \mathrm{~m}(6 \mathrm{ft})$.

- Analytical results from liquid and solid samples collected from the two septic tanks did not indicate any constituents of concern (COC) above the PALs. Both septic tanks were closed in place as described above.

- Analytical results from liquid and solid samples collected from the two USTs indicated the presence of TPH above the PAL. Both USTs were removed as described above.

- During excavation and removal of the two USTs, evidence was found that the tanks had leaked so the areas were over-excavated. All of the excavated soil was containerized and shipped to the NTS Area 6 hydrocarbon landfill for disposal. Confirmation samples collected from the bottom of the tank excavations showed that all of the hydrocarbon impacted soil had been removed. 
The following tables list the CASs with COCs below the PALs (Table 2-1) and the CASs with COCs above the PALs (Table 2-2). Table 2-2 also lists the contaminant of concern and an estimate of the volume of contaminated material. Details of the methods used to conduct the field investigation activities and the results of the investigations are presented in Appendix D.

\subsection{Need for Corrective Action}

Investigation activities provided sufficient information to establish the need for corrective action. The sites have been grouped according to the results of the investigation activities to facilitate discussion of remediation strategies.

- Sites with no COCs or debris: COCs were found only in isolated detections at low levels, if at all, resulting in the areas being determined to not be contaminated based on the statistical layer analysis conducted during the preliminary investigation activities (see Corrective Action Investigation Report). The sites which were cleaned up under accelerated programs such as the housekeeping sites, the two USTs, and the two septic tank closures are included in this group. There are no known sources and there are no exposure pathways; therefore, no further action is required.

- Sites with no COCs but with visible debris: COCs were found only in isolated detections at low levels, if at all, resulting in the areas being determined to not be contaminated based on the statistical layer analysis conducted during the preliminary investigation activities. Therefore, there is no known source and there are no existing exposure pathways. However, nonhazardous solid waste is still visible at the surface so corrective actions should prevent or mitigate human exposure to the waste. Corrective actions should either remove or protectively cover the debris currently exposed.

- Sites with COCs found in soil covered by 0.6 to $1.8 \mathrm{~m}$ (2 to $6 \mathrm{ft}$ ) of clean material: COCs were found at several locations in each area above the PAL resulting in the areas being classified as contaminated based on the statistical layer analysis conducted during the preliminary investigation activities. As these areas are presently covered and in areas that are not subject to rapid erosion, the most probable exposure pathway is through excavation of the contaminated soil. The corrective action should prevent or mitigate human exposure to the contaminated subsurface soils by leaving them in place or possibly by installing a thicker cover. 
Table 2-1

Clean Corrective Action Sites

\begin{tabular}{|c|c|c|c|}
\hline CAS No. & $\begin{array}{r}\text { General } \\
\text { Location }\end{array}$ & Corrective Action Site Description & Comments \\
\hline $58-05-01$ & UC-1 & Septic system for the support trailer park & \\
\hline $58-07-01$ & UC-1 & Decon facility pit - Area Z (U1Z) - west of the Central Mud Pit & Same as $58-35-01$ \\
\hline $58-35-01$ & UC-1 & Burn Pit & $\begin{array}{l}\text { Same as } 58-07-01 \text {. Burned material } \\
\text { is asphalt lined plastic used to line } \\
\text { pit. }\end{array}$ \\
\hline $58-09-04$ & UC-1 & Mud Pit B/borrow pit (U1B) - southeast of UC-1 & Drill pad for well HTH-1 \\
\hline $58-09-05$ & UC-1 & Mud Pit C (U1C) - northeast of UC-1 & \\
\hline $58-09-05$ & UC-1 & Mud Pit D (U1D) - southeast of UC-1 & \\
\hline $58-44-01$ & UC-1 & Drilling mud/grout - Area X (U1X) - west of Central Mud Pit & \\
\hline $58-44-02$ & UC-1 & Drilling mud/grout - Area X (U1X) - southeast of UC-1 & \\
\hline $58-44-05$ & UC-1 & Grout piles - Area X (U1X) - northeast of UC-1 & \\
\hline $58-98-03$ & UC-1 & Waste pile - southwest of the Central Mud Pit & \\
\hline $58-05-02$ & UC-3 & Septic system - east of UC-3 & \\
\hline $58-05-03$ & UC-3 & UST at UC-3 recording trailer park & UST and impacted soil removed \\
\hline $58-05-05$ & UC-3 & Septic system - southeast of UC-3 & Septic tank closed in place \\
\hline $58-05-06$ & UC-3 & Septic system at the UC-3 recording trailer park & Septic tank closed in place \\
\hline $58-09-06$ & UC-3 & Mud Pit A (U3A) - northwest of UC-3 & \\
\hline $58-09-06$ & UC-3 & Mud Pit B (U3B) - north of UC-3 & \\
\hline $58-09-06$ & UC-3 & Mud Pit C (U3C) - northeast of UC-3 & \\
\hline $58-09-06$ & UC-3 & Mud Pit D (U3D) - northeast of UC-3 & \\
\hline $58-10-06$ & UC-3 & Drilling mud/cuttings - Area X (U3X) - north of UC-3 & \\
\hline $58-19-01$ & UC-3 & Scrap and trash dump - west of UC-3 recording trailer park & Never located in the field \\
\hline $58-35-02$ & UC-3 & Burn Area UC-3 recording trailer park & \\
\hline $58-44-04$ & UC-3 & Drilling mud/grout spill-Area Y (U3Y) - southwest of UC-3 & \\
\hline $58-98-01$ & UC-3 & Waste pile - adjacent to UC-3 Mud Pit A & \\
\hline $58-98-02$ & UC-3 & Waste pile - south of UC-3 & \\
\hline $58-98-04$ & UC-3 & Waste pile - southeast of UC-3 & \\
\hline $58-99-01$ & UC-3 & Protruding pipes - UST (U3U) - southeast of UC-3 & UST and impacted soil removed \\
\hline $58-09-03$ & UC-4 & Mud Pit E (U4E) - southwest of UC-4 & \\
\hline $58-05-04$ & UC-4 & Septic system west of UC-4 Mud Pit A & \\
\hline
\end{tabular}


Table 2-2

Contaminated Corrective Action Sites

\begin{tabular}{|c|c|c|c|c|}
\hline CAS No. & $\begin{array}{l}\text { General } \\
\text { Location }\end{array}$ & Corrective Action Site Description & $\begin{array}{c}\text { Range of TPH } \\
\text { Contamination } \\
\mathrm{mg} / \mathrm{kg} \\
\end{array}$ & $\begin{array}{c}\text { Estimated } \\
\text { Volume } \\
\text { (cubic meters) }\end{array}$ \\
\hline $58-09-01$ & CMP & Large mud pit - east of UC-1 & 6 to 2,560 & 40,182 \\
\hline $58-09-02$ & UC-1 & Mud Pit A (U1A) - southwest of CMP & 13 to 710 & 544 \\
\hline $58-09-05$ & UC-1 & Mud Pit E (U1E) - east of UC-1 & 13 to 632 & 636 \\
\hline $58-10-03$ & UC-1 & Shaker pad area (U1S) - east of UC-1 & 13 to 4,500 & 1,087 \\
\hline $58-44-06$ & UC-1 & $\begin{array}{l}\text { Grout pile area Y (U1Y) - UC-1 recording } \\
\text { trailer park }\end{array}$ & 13 to 197 & 23 \\
\hline $50-09-06$ & UC-3 & Mud Pit E (U3E) - southwest of UC-3 & 13 to 15,440 & 1,699 \\
\hline $58-10-01$ & UC-3 & Shaker pad (U3S) - northeast of UC-3 & 14 to 1,670 & 141 \\
\hline $58-25-01$ & UC-3 & U3E southern outlier - south of Mud Pit U3E & 13 to 17,010 & 8,563 \\
\hline $58-44-03$ & UC-3 & $\begin{array}{l}\text { Drill mud/grout - Area Z (U3Z) - southeast of } \\
\text { UC-3 }\end{array}$ & 13 to 676 & 783 \\
\hline $58-09-03$ & UC-4 & Mud Pit A (U4A) - west of UC-4 & 14 to 336 & 2,174 \\
\hline $58-09-03$ & UC-4 & Mud Pit B (U4B) - southwest of UC-4 & 11 to 248 & 725 \\
\hline $58-09-03$ & UC-4 & Mud Pit C (U4C) - southwest of UC-4 & 18 to 985 & 1,359 \\
\hline $58-09-03$ & UC-4 & Mud Pit D (U4D) - south of UC-4 & 13 to 1,700 & 2,447 \\
\hline $58-10-02$ & UC-4 & Shaker pad - Area S (U4S) - north of UC-4 & 13 to 862 & 5,439 \\
\hline $58-10-04$ & UC-4 & Shaker pad - Area W (U4W) - south of UC-4 & 14 to 301 & 362 \\
\hline $58-10-05$ & UC-4 & Shaker pad - Area X (U4X) - northeast of UC-4 & 22 to 131 & 90 \\
\hline
\end{tabular}


- Sites with COCs present at the surface: COCs were found at several locations in each area above the PAL resulting in the areas being classified as contaminated based on the statistical layer analysis conducted during the preliminary investigation activities. As these areas are not covered, the most likely exposure pathway is through direct contact with the contaminated soils. The corrective action should prevent or mitigate human exposure to the contaminated surface soils by removing them or installing a protective cover over them.

The COCs identified above the PAL as listed in the CAIP (DOE/NV, 1997) and the Addendum to the CAIP (DOE/NV, 1998) are limited to TPH associated with drilling waste in the mud pits, shaker pad areas, and cutting disposal areas. Therefore, an evaluation of possible remedial alternatives is required for these 18 sites to ensure worker, public, and environmental protection against potential exposure to contamination.

During and after the investigation activities several of the sites which had surface debris but no COCs were cleaned up as housekeeping sites. The two septic tanks which were sampled and proven to not contain any constituents above the PALs were cleaned out and closed in place by filling them with clean material from the site in accordance with Nevada Department of Health requirements. In addition, the two USTs that had TPH concentrations in the liquid and solids in the tanks above the PALs were closed in accordance with NDEP policy by removing the contents, excavating around the tanks, and then removing them. There was visible leakage from the tanks so the area under the tanks was over excavated before confirmation samples were collected. The confirmation samples showed that all contaminated soil had been removed. The tanks and all of the excavated soil were shipped to the NTS for disposal at an approved facility. The excavations were backfilled with clean material from the site. 


\subsection{Evaluation of Alternatives}

The purpose of this section is to present the corrective action objectives for CAU 417, describe the general standards and decision factors used to screen the corrective action alternatives, and to develop and evaluate a set of corrective action alternatives that could be used to meet the corrective action objectives.

\subsection{Corrective Action Objectives}

The corrective action objectives are media-specific goals for protecting human health and the environment. They are expressed in terms of contaminants, media of interest, potential exposure pathways, and cleanup goals so that an appropriate range of waste management options can be developed for analysis.

Based on the potential exposure pathways, the following corrective action objective has been identified for CAU 417: prevent or mitigate human exposure to surface and subsurface soils with contaminant concentrations above the PAL of $100 \mathrm{mg} / \mathrm{kg} \mathrm{TPH}$.

The corrective action objective is risk-based. As subjective risk analysis based on factors (a) through (k) in NAC 445A.227 was prepared and is provided in Appendix B to show that leaving the majority of the contaminated material in place and providing a protective cover over material with contaminants above the PAL exposure at the surface does not pose an unacceptable risk to human health or the environment.

\subsubsection{Constituents of Concern}

Analyses conducted during the corrective action investigation were evaluated to determine COCs for CAU 417. Petroleum hydrocarbons were identified above the State of Nevada petroleum hydrocarbon action level of $100 \mathrm{mg} / \mathrm{kg}$ (NAC, 1996b) in the following CASs. No other COCs were identified. 


\section{UC-1 Corrective Action Sites}

58-09-01 Central Mud Pit

58-09-02 Mud Pit U1A

58-09-05 Mud Pit U1E

58-10-03 Shaker Pad Area (U1S)

58-44-06 Grout Pile (U1Y)

\section{UC-3 Corrective Action Sites}

58-09-06 Mud Pit U3E

58-10-01 Shaker Pad Area (U3S)

58-25-01 Spill Southern Outlier (U3E)

58-44-03 Drill Mud/Grout Spill Area (U3Z)

\section{UC-4 Corrective Action Sites}

58-09-03 Mud pits U4A, U4B, U4C, U4D

58-10-02 Shaker Pad Area (U4S)

58-10-04 Shaker Pad Area (U4W)

58-10-05 Shaker Pad Area (U4X)

Petroleum hydrocarbon concentrations were not detected above the State of Nevada petroleum hydrocarbon action level of $100 \mathrm{mg} / \mathrm{kg}$ (NAC, 1996b) in the following CASs. No other COCs were identified above PALs.

\section{UC-1 Corrective Action Sites}

58-05-01 Septic System

58-07-01 Decon Facility Pit (same as 58-35-01 Burn Area)

58-35-01 Burn Pit

58-09-04 Drill Pad (old name: Mud Pit U1B)

58-09-05 Equipment \& Staging Areas (old name: Mud Pit U1C)

58-09-05 Equipment \& Staging Areas (old name: Mud Pit U1D)

58-44-01 Drilling mud/grout piles (UC-1 Area X West of CMP)

58-44-02 Drilling mud/grout piles (UC-1 Area X Southeast of UC-1)

58-44-05 Grout Pile (UC-1 Area X Northeast of UC-1)

58-98-03 Waste Pile

\section{UC-3 Corrective Action Sites}

58-05-02 Septic System

58-05-03 Recording Trailer Park UST

58-99-01 UST (U3U) (old name: protruding pipes)

58-05-05 Septic System

58-05-06 Recording Trailer Park Septic Tank (old name: septic system) 
58-09-06 Mud pits U3A, U3B, U3C, U3D

58-10-06 Drill Mud/Cuttings (U3X)

58-19-01 Scrap \& Trash Dump

58-35-02 Burn Area

58-44-04 Drill Mud/Grout Spill Area (U3Y)

58-98-01 Waste Pile

58-98-02 Waste Pile

58-98-04 Waste Pile

\section{UC-4 Corrective Action Sites}

58-05-04 Septic System

58-09-03 Mud Pit U4E

Not Assigned Scrap \& Trash Dump (east of UC-4 SGZ)

\subsubsection{Potential Exposure Pathways}

As part of the CAIP (DOE/NV, 1997), a conceptual model for CAU 417 was developed which identified the potential exposure pathways as ingestion and/or inhalation of contaminated soil and dermal contact with soils resulting from intrusion into the mud pits and shaker pad areas under recreational and occupational scenarios.

\subsection{Screening Criteria}

The screening criteria used to evaluate and select the preferred corrective action alternatives are identified in the EPA Guidance on RCRA Corrective Action Decision Documents (EPA, 1991) and the Final RCRA Corrective Action Plan (EPA, 1994).

The corrective action alternatives will be evaluated based on four general corrective action standards and five remedy-selection decision factors. All corrective action alternatives must meet the general standards to be selected for evaluation using the remedy-selection decision factors. 
The general corrective action standards are:

- Protect human health and the environment

- Comply with media cleanup standards

- Control the source(s) of the release

- Comply with applicable federal, state, and local standards for waste management

The remedy-selection decision factors are:

- Short-term reliability and effectiveness

- Reduction of toxicity, mobility, and/or volume

- Long-term reliability and effectiveness

- Feasibility

- Cost

\subsubsection{Corrective Action Standards}

The following describes the corrective action standards used to evaluate the corrective action alternatives.

\subsubsection{Protection of Human Health and the Environment}

Protection of human health and the environment is a general mandate of the RCRA statute (EPA, 1994). This mandate requires that the corrective action includes any measures that are needed to be protective. These measures may or may not be directly related to media cleanup, source control, or management of wastes. The closure option is evaluated for the ability to meet corrective action objectives as defined in Section 3.1.

\subsubsection{Compliance with Media Cleanup Standards}

Each corrective action alternative must meet the proposed media cleanup standards set forth in applicable state and federal regulations.

\subsubsection{Control the Source(s) of the Release}

An objective of corrective action remedies is to stop further environmental degradation by controlling or eliminating additional releases that may pose a threat to human health and the environment. Unless source control measures are taken, efforts to clean up releases may be ineffective or, at best, will essentially involve a perpetual cleanup. Therefore, each corrective action alternative must use an effective source control program to ensure the long-term effectiveness and protectiveness of the corrective action. 


\subsubsection{Comply with Applicable Federal, State, and Local Standards for Waste Management}

During implementation of any corrective action alternative, all waste management activities must be conducted in accordance with applicable state and federal regulations (e.g., Nevada Revised Statutes [NRS] 459.400 - 459.600 [NRS, 1995]; RCRA 40 Code of Federal Regulations CFR 261 - 281 [CFR, 1996]; 40 CFR 268, Land Disposal; NAC 459.9974, "Disposal and Evaluation of Contaminated Soil" [NAC, 1996a]). The requirements for management of the waste, if any, derived from the corrective action will be determined based on applicable state and federal regulations, field observations, process knowledge, characterization data, and data collected and analyzed during corrective action implementation. Administrative controls (e.g., decontamination procedures and corrective action strategies) will minimize waste generated during site corrective action activities. Decontamination activities will be performed in accordance with approved procedures and will be designated according to the COCs present at the site.

\subsubsection{Remedy Selection Decision Factors}

The following describe the remedy selection decision factors used to evaluate the corrective action alternatives.

\subsubsection{Short-Term Reliability and Effectiveness}

Each corrective action alternative must be evaluated with respect to its effects on human health and the environment during the construction and implementation phase of the corrective action. The following factors will be addressed for each alternative:

- Protection of the community from potential risks associated with implementation such as fugitive dusts, transportation of hazardous materials, or air-quality impacts from off-gas emissions

- Protection of workers during construction and implementation

- Environmental impacts that may result from construction and implementation

- The amount of time until the corrective action objectives are achieved

\subsubsection{Reduction of Toxicity, Mobility, and/or Volume}

Each corrective action alternative must be evaluated for its ability to reduce the toxicity, mobility, and/or volume of the contaminated media. Reduction in toxicity, mobility, and/or volume refers 
to changes in one or more characteristics of the contaminated media by the use of corrective measures that decrease the inherent threats associated with that media.

\subsubsection{Long-Term Reliability and Effectiveness}

Each corrective action alternative must be evaluated in terms of risk remaining at the CASs after corrective action alternatives have been implemented. The primary focus of this evaluation is on the extent and effectiveness of the controls that may be required to manage risk posed by treatment residuals and/or untreated wastes.

\subsubsection{Feasibility}

Feasibility addresses the technical and administrative ability of a corrective action alternative and the availability of various services and materials needed during implementation. Each corrective action alternative must be evaluated for the following criteria:

- Construction and Operation; this refers to the feasibility of implementing a corrective action alternative given the existing set of waste and site-specific conditions.

- Administrative Feasibility; this refers to the administrative activities needed to implement the corrective action alternative (e.g., permits, public acceptance, regulatory acceptance, FFACO deadlines, rights-of-way, on- and off-site approval).

- Availability of Services and Materials; this refers to the availability of adequate off-site and on-site treatment, storage capacity, disposal services, outside technical services and materials, and availability of prospective technologies for each corrective action alternative.

\subsubsection{Cost}

The cost estimate for each corrective action alternative shall include both capital and operation and maintenance costs, if applicable. The following is a brief description of each component:

- Capital Costs; these costs include both direct and indirect costs. Direct costs may consist of materials, labor, mobilization, demobilization, site preparation, construction materials, equipment purchase and rental, sampling and analysis, waste disposal, and health and safety measures. Indirect costs include such items as engineering design, permits and/or fees, start-up costs, and any contingency allowances.

- Operation and Maintenance; these costs include labor, training, sampling and analysis, maintenance materials, utilities, and health and safety measures.

Cost estimates were developed by Bechtel Nevada. Details for the estimated costs for this CADD are provided in Appendix B. 


\subsection{Development of Corrective Action Alternatives}

This section identifies and briefly describes the viable corrective action technologies and the corrective action alternatives considered for the affected media. Based on the review of existing data, future land use, and current operations at the CNTA, the following alternatives have been developed for consideration at the CAU 417 CASs:

\section{Alternative 1 - No Action}

\section{Alternative 2 - Administrative Controls}

Alternative 3 - Clean Closure

\section{Alternative 4 - Bioremediation}

The following information supports the protection of groundwater from CAU 417 CASs and eliminates the need for groundwater monitoring in accordance with NAC 445A.227

(NAC, 1996b):

- The depth to groundwater at the site ranges from approximately $61 \mathrm{~m}(200 \mathrm{ft})$ by UC-3 to $163 \mathrm{~m}(535 \mathrm{ft})$ by UC-4 (DOE/NV, 1996a).

- The soils found in the CAU 417 CASs are native soils consisting of moderately permeable sandy, gravelly, cobbly, or stony loams derived from various alluvial sources (DOA, 1974). Geotechnical analysis determined that the alluvial/fill material has very low hydraulic conductivity and soil moisture content within the low range. Both these factors limit the migration potential through the soils.

- Precipitation averages 13 to 15 centimeters $(\mathrm{cm})$ (5 to 6 inches [in.]) per year at CNTA (Schaeffer, 1968). Annual evaporation is between 147 and $168 \mathrm{~cm}$ (58 and $60 \mathrm{in}$.) (DOE/NV, 1996a). Most of the precipitation evaporates before and shortly after infiltration so only a small percentage of the precipitation adds to soil moisture (Rush and Everett, 1966). The low precipitation and high evaporation create a negative water balance for the area so there is no driving force associated with precipitation to mobilize contaminants to the groundwater.

- No evidence of COCs above regulatory limits was found, except the petroleum hydrocarbons in the CASs listed in Section 3.1.1. Other waste encountered during the investigation consisted of construction debris, such as concrete, wood, asphalt, metal, and wire. The conditions under which the contamination was detected do not present any significant migration potential or associated effect on waters of the state 
- Based on the investigation, the extent of the contamination is limited to the petroleum hydrocarbons in those CASs listed in Section 3.1.1. Soil moisture and sampling results show no indication of continued downward migration of contaminants.

- No COCs were identified at levels with the potential for a hazard related to fire, vapor, or explosion.

No other site-specific information is available that could substantiate the potential for contaminant migration. Existing covers act as additional barriers to water infiltration. Based on this information, neither vadose nor groundwater monitoring is considered necessary for CAU 417.

\subsubsection{Alternative 1 - No Action}

Under the no-action alternative, no corrective action activities will be implemented. This alternative is used as a starting point to establish a baseline for comparison with the other corrective action alternatives.

\subsubsection{Alternative 2 - Administrative Controls}

Administrative controls are used to prevent inadvertent contact with contaminated media. Administrative controls can consist of use restrictions, water-right restrictions, and restrictions on activities such as excavation. Use restrictions will be placed on the land to prohibit intrusive activities and farming. Signs can be used to further restrict access. Administrative controls are commonly used and can effectively eliminate potential pathways.

Under this alternative, partial excavation of impacted materials and installation of an engineered cover or backfill may be implemented at CAU 417 CASs to mitigate surface depressions, land subsidence, and/or surface impacted media. In addition, some maintenance activities would be conducted on the CASs that contain soils impacted with petroleum hydrocarbon levels above the $100 \mathrm{mg} / \mathrm{kg}$ TPH action level (NAC, 1996b). Maintenance activities may include the repair of existing or engineered covers, area contouring, area grading, and backfilling.

Native borrow soils will be used for backfilling, area grading, and/or covering activities. Borrow soils will be obtained from areas within CNTA Land Withdrawal Boundaries. Excavated soils that contain petroleum hydrocarbons exceeding $100 \mathrm{mg} / \mathrm{kg}$ will be disposed of at the UC-1 Central Mud Pit, the NTS Area 6 Hydrocarbon Landfill, and/or other approved/licensed landfills. The implementation of administrative controls requires the coordination of all entities at a site to 
ensure that the restrictions are enforced. Post closure inspection plans will be proposed in the Corrective Action Plan (CAP).

\subsubsection{Close in Place With Site Posting}

Impacted soils will be left in place; therefore, restrictions may be required to prevent intrusive activities. This alternative includes the installation of monuments and signs, as-built surveying, and visual inspections (on a regular basis). Site posting will consist of placing a concrete or metal monument at the site. The monument will have a sign attached indicating the presence of subsurface impacted materials, warning of site disturbances (subsurface intrusions), and providing agency contact information.

Factors considered while evaluating corrective action alternatives include petroleum hydrocarbon impacted soil depth, concentration, volume, vegetation presence, and existing soil cover presence. No remedial actions, such as backfilling, area grading, compaction, and recontouring will take place.

\subsubsection{Partial Excavation With Engineered Backfill}

This alternative includes the administrative controls listed in Sections 3.3.2.1 as well as the selective removal (partial excavation) of soils in CASs with petroleum hydrocarbons impacting surface and subsurface media. This alternative also includes the backfill and compaction of the excavation (engineered backfill) with uncontaminated soil. Excavation activities may disturb the existing soil cover and its permeability. The engineered backfill will obtain a permeability equal to or less than the existing permeability of the adjacent native soil. Petroleum hydrocarbon impacted soil depth, concentration, volume, geographic location (i.e., arroyo, flood plain, slope, etc.), vegetation presence, and existing soil cover presence are evaluated to determine applicability of this alternative.

\subsubsection{Construction of Engineered Cover}

This alternative includes the administrative controls in Section 3.3.2.1 and the construction of an engineered cover over CASs with petroleum hydrocarbons impacting surface or subsurface soils. Covering involves the installation of a soil barrier over the surface impacted areas to control erosion, limit precipitation infiltration, and mitigate potential exposure pathways. The engineered cover will consider site characteristics such as soil properties, topography, drainage (i.e., flooding), and structural geology (i.e., faults). The engineering design, and specifications for the cover will be provided in the CAP. 


\subsubsection{Alternative 3 - Clean Closure}

Under the clean closure alternative, TPH impacted media above the $100 \mathrm{mg} / \mathrm{kg}$ action level will be removed from the affected CASs. Activities will consist primarily of excavation and waste disposal. Petroleum hydrocarbon impacted soils will be excavated and transported to the UC-1 CMP, the NTS Area 6 Hydrocarbon Landfill, and/or another approved/licensed landfill.

Excavated areas will be backfilled, and/or regraded. No COCs or potential hazards above cleanup action levels will remain at the clean-closed CASs; therefore, visual inspections of the site and installation of monuments and signs will not be necessary. No post-closure monitoring will be conducted after implementing the Clean Closure alternative. Verification of clean closure will be accomplished by collecting soil samples at the base of excavations for laboratory analysis. Details of verification sampling will be given in the CAP.

\subsubsection{Disposal at the NTS}

Hydrocarbon impacted wastes, generated from excavation activities, may be transported to and disposed of in the NTS Area 6 Hydrocarbon Landfill. The average volume of impacted media (based upon transportation weight restrictions) per load is approximately 11.5 cubic meters $\left(\mathrm{m}^{3}\right)$ (15 cubic yards $\left[\mathrm{yd}^{3}\right]$ ) of soil. The distance between the CNTA and the NTS is approximately 418 $\mathrm{km}(260 \mathrm{mi})$, thus resulting in an approximate travel cycle of 12 hours per load. This activity is considered to be resource intensive; however, disposal cost is minimized (approximately $\$ 10$ per $\left.\mathrm{yd}^{3}\right)$.

\subsubsection{Disposal at the UC-1 Central Mud Pit}

Hydrocarbon impacted media generated from excavation activities will be transported, consolidated, and disposed of in the UC-1, CMP, CAS 58-09-01. The UC-1 CMP consists of approximately 40,182 $\mathrm{m}^{3}\left(52,556 \mathrm{yd}^{3}\right)$ of petroleum hydrocarbon impacted drilling mud and soil, ranging from $0 \mathrm{~m}$ to $2 \mathrm{~m}$ ( $0 \mathrm{ft}$ to $6 \mathrm{ft}$ ) in depth. After completion of excavation and disposal activities from the above mentioned TPH impacted CASs, an engineered cover will be constructed over CAS No. 58-09-01. Based upon travel distance (less than $6.4 \mathrm{~km}$ [4 mi] from any site and no disposal fees), this activity is considered to be less resource intensive than disposal at the NTS or a private facility.

\subsubsection{Disposal at a Private Facility}

Hydrocarbon impacted wastes, generated from excavation activities, may be transported to and disposed of in the nearest private facility that is permitted for hydrocarbon disposal. The average volume of impacted media (based upon transportation weight restrictions) per load is 
approximately $11.5 \mathrm{~m}^{3}\left(15 \mathrm{yd}^{3}\right)$ of soil. The distance between the CNTA and Las Vegas or Reno disposal facilities is approximately $402 \mathrm{~km}(250 \mathrm{mi})$ and $483 \mathrm{~km}$ (300 mi), respectively. This results in approximate travel cycles of 12 and 15 hours per load to Las Vegas and Reno, respectively. Depending upon disposal location and impacted media, disposal at a private facility is considered to be resource intensive. Disposal costs will vary between approximately $\$ 75$ per $\mathrm{yd}^{3}$ to $\$ 200$ per $\mathrm{yd}^{3}$.

\subsubsection{Alternative 4 - Bioremediation}

Bioremediation is used to reduce the chemical impact in soil and water systems through microbial processes. Bioremediation requires the characterization of COC transport mechanisms in impacted media, the evaluation of factors affecting the long-term maintenance of the COC degradation process, and the monitoring of degradation processes for the purpose of meeting necessary process requirements, as they may occur. In situ bioremediation and landfarming are identified as potential alternatives for CAU 417 and are described in Sections 3.3.4.1 and 3.3.4.2, respectively.

\subsubsection{In Situ Bioremediation}

In situ bioremediation of hydrocarbon impacted soils consists of stimulating microbial degradation through the installation of a system that provides nutrients and oxygen to the impacted media. Analyses of microbial parameters at the sites would provide design and implementation information. The system would consist of several vadose zone wells to allow air flow, monitoring, and introduction of nutrients. Temporary fencing would be installed to protect the bioremediation well system until remediation is completed. Gas samples from the system would be periodically collected to monitor degradation rates. Depending upon system design, an Air Discharge Permit may be required prior to implementation of vapor extraction activities.

The system configuration and monitoring scheme would be developed in the corrective action plan. With time, the in situ bioremediation system could result in reduction of TPH concentrations to below the $100 \mathrm{mg} / \mathrm{kg}$ TPH action level. Materials containing drilling mud may require additional time, or a combination of technologies (i.e., fracture propagation), to meet remediation requirements. After remediation, the wells would be closed according to State of Nevada requirements. 


\subsubsection{On-Site Landfarming}

On-site landfarming consists of physical mixing of the impacted media with nutrients, water, and microorganisms (native or imported) to degrade the constituents into carbon dioxide and water. The analyses of microbial parameters at the sites would provide information to be used in the planning and implementation. Landfarming techniques may include the removal of petroleum hydrocarbon impacted soils and the placement of impacted soils in a designated processing area. If petroleum hydrocarbon impact is less than $0.91 \mathrm{~m}(3 \mathrm{ft})$ below ground surface, microbial activity

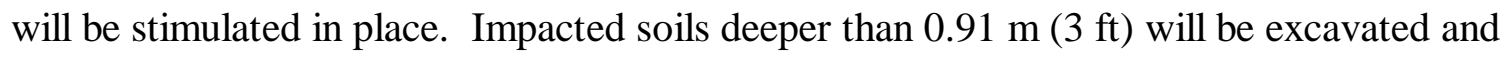
processed above ground. Fencing would be installed to inhibit access to the areas where the soil is processed. An Air Discharge Permit may be required prior to the implementation of landfarming activities.

With time, landfarming could result in reduction of TPH to concentrations below the $100 \mathrm{mg} / \mathrm{kg}$ TPH action level. After remediation, the soils/drill muds would be returned to the excavation areas, and the areas would be regraded.

\subsection{Evaluation and Comparison of Alternatives}

The general corrective action standards and remedy-selection decision factors described in Section 3.2 were used to conduct a comparative evaluation of each corrective action alternative. In the evaluation each corrective action alternative was compared to the other alternatives. In this way the advantages and disadvantages of each alternative are assessed in order to select a preferred alternative for each CAS. Tables 3-1 and 3-2 present a comparative evaluation of closure standards and remedy selection decision factors, respectively, for each alternative.

The preferred corrective action alternatives were evaluated on their technical merits, focusing on performance, reliability, feasibility, and safety. The alternatives were judged to meet all requirements for the technical components evaluated. These alternatives meet all applicable state and federal regulations for closure of the sites and will reduce future exposure pathways into the contents of the sites. During corrective action implementation, these alternatives will present minimal potential threat to site workers in contact with the waste. However, appropriate safety procedures will be developed and implemented for site activities. 
Table 3-1

Detailed Closure Standards Evaluation of Alternatives for CASs Exceeding Action Levels

(Page 1 of 2)

\begin{tabular}{|c|c|c|c|c|}
\hline $\begin{array}{l}\text { CLOSURE STANDARD } \\
\text { EVALUATION CRITERIA }\end{array}$ & $\begin{array}{l}\text { ALTERNATIVE } 1 \\
\text { NO ACTION }\end{array}$ & $\begin{array}{c}\text { ALTERNATIVE } 2 \\
\text { ADMINISTRATIVE CONTROLS } \\
\end{array}$ & $\begin{array}{l}\text { ALTERNATIVE } 3 \\
\text { CLEAN CLOSURE }\end{array}$ & $\begin{array}{l}\text { ALTERNATIVE } 4 \\
\text { BIOREMEDIATION }\end{array}$ \\
\hline $\begin{array}{l}\text { Protection of Human } \\
\text { Health and the } \\
\text { Environment }\end{array}$ & $\begin{array}{l}\text { - Does not meet closure objectives } \\
\text { of preventing inadvertent } \\
\text { intrusion into impacted zone(s) } \\
\text { - No worker exposure associated } \\
\text { with implementation } \\
\text { - Existing cover for subsurface } \\
\text { impacted sites prevents } \\
\text { infiltration } \\
\text { - No maintenance to ensure cover } \\
\text { integrity for subsurface impacted } \\
\text { sites } \\
\text { - COCs do not pose a significant } \\
\text { risk }\end{array}$ & $\begin{array}{l}\text { - Meets closure objectives } \\
\text { - Prevents inadvertent intrusion } \\
\text { into impacted zone(s) } \\
\text { - No worker exposure associated } \\
\text { with implementation for } \\
\text { subsurface impacted sites; } \\
\text { however, there may be a higher } \\
\text { risk to workers during } \\
\text { implementation at surface } \\
\text { impacted sites or during } \\
\text { disturbance of impacted } \\
\text { materials } \\
\text { - Existing or constructed covers } \\
\text { prevent infiltration to COCs } \\
\text { during precipitation events } \\
\text { - Partial excavation and covering } \\
\text { will reduce the highest } \\
\text { concentrations of COCs; } \\
\text { however, COC levels only } \\
\text { slightly elevated over media } \\
\text { cleanup standard for TPH } \\
\text { - Covering and maintenance } \\
\text { ensures integrity } \\
\text { - COCs do not pose significant } \\
\text { risk }\end{array}$ & $\begin{array}{l}\text { - Meets closure objectives } \\
\text { - Prevents intrusion } \\
\text { - Higher risk to workers during } \\
\text { implementation } \\
\text { - Eliminates exposure pathway by } \\
\text { removing COC levels over media } \\
\text { cleanup standard for TPH } \\
\text { - COCs do not pose significant risk }\end{array}$ & $\begin{array}{l}\text { - Meets closure objectives } \\
\text { - Higher risk to workers during } \\
\text { implementation } \\
\text { - Eliminates exposure pathway by } \\
\text { removing COC levels over } \\
\text { media cleanup standard for TPH } \\
\text { - Prevents intrusion at completion } \\
\text { of bioremediation activities } \\
\text { - A cover may be required to be } \\
\text { installed to stabilize the } \\
\text { materials at the Central Mud Pit } \\
\text { - COCs do not pose significant } \\
\text { risk }\end{array}$ \\
\hline $\begin{array}{l}\text { Compliance with Media } \\
\text { Cleanup Standards }\end{array}$ & $\begin{array}{l}\text { Does not comply because COCs } \\
\text { above media cleanup standards } \\
\text { remain in place } \\
\text { - Inadvertent intrusion is not } \\
\text { prevented }\end{array}$ & $\begin{array}{l}\text { - Complies with media cleanup } \\
\text { standards by eliminating } \\
\text { exposure pathways for } \\
\text { subsurface impacted sites }\end{array}$ & $\begin{array}{l}\text { - Complies by removing COCs } \\
\text { above media cleanup standards }\end{array}$ & $\begin{array}{l}\text { - Complies by degrading COCs } \\
\text { above media cleanup standards }\end{array}$ \\
\hline $\begin{array}{l}\text { Control the Source(s) of } \\
\text { Release }\end{array}$ & $\begin{array}{l}\text { Does not control migration of } \\
\text { COCs at surface impacted sites } \\
\text { or through intrusive activities at } \\
\text { surface or subsurface impacted } \\
\text { sites }\end{array}$ & $\begin{array}{l}\text { - Maintenance of the existing or } \\
\text { engineered cover prevents } \\
\text { migration of COCs from } \\
\text { intrusive activities and } \\
\text { precipitation events } \\
\text { - Surface impacted areas do not } \\
\text { control migration from } \\
\text { precipitation events }\end{array}$ & $\begin{array}{l}\text { - COCs removed to media cleanup } \\
\text { standards } \\
\text { - Transportation accidents could } \\
\text { release COCs }\end{array}$ & $\begin{array}{l}\text { - COCs degraded to cleanup } \\
\text { levels }\end{array}$ \\
\hline
\end{tabular}


Table 3-1

Detailed Closure Standards Evaluation of Alternatives for CASs Exceeding Action Levels

(Page 2 of 2)

\begin{tabular}{|c|c|c|c|c|}
\hline $\begin{array}{l}\text { CLOSURE STANDARD } \\
\text { EVALUATION CRITERIA }\end{array}$ & $\begin{array}{l}\text { ALTERNATIVE } 1 \\
\text { NO ACTION } \\
\end{array}$ & $\begin{array}{c}\text { ALTERNATIVE } 2 \\
\text { ADMINISTRATIVE CONTROLS } \\
\end{array}$ & $\begin{array}{l}\text { ALTERNATIVE } 3 \\
\text { CLEAN CLOSURE } \\
\end{array}$ & $\begin{array}{l}\text { ALTERNATIVE } 4 \\
\text { BIOREMEDIATION } \\
\end{array}$ \\
\hline $\begin{array}{l}\text { Comply with Applicable } \\
\text { Federal, State, and Local } \\
\text { Standards for Waste } \\
\text { Management }\end{array}$ & - No wastes generated & $\begin{array}{l}\text { - Waste could be generated for } \\
\text { partial excavation and covering } \\
\text { activities } \\
\text { - Waste will be handled, } \\
\text { transported, and disposed per } \\
\text { applicable standards }\end{array}$ & $\begin{array}{l}\text { - Significant volume of waste } \\
\text { generated } \\
\text { - Waste will be handled, } \\
\text { transported, and disposed per } \\
\text { applicable standards }\end{array}$ & $\begin{array}{l}\text { - Minimal waste generated } \\
\text { - Waste will be handled, } \\
\text { transported, and disposed per } \\
\text { applicable standards }\end{array}$ \\
\hline
\end{tabular}




\section{Table 3-2}

\section{Detailed Remedy Selection Decision Factors Evaluation of Alternatives for CASs Exceeding Action Levels}

(Page 1 of 2)

\begin{tabular}{|c|c|c|c|c|}
\hline $\begin{array}{l}\text { REMEDY SELECTION } \\
\text { DECISION FACTORS } \\
\text { EVALUATION CRITERIA } \\
\end{array}$ & $\begin{array}{l}\text { ALTERNATIVE } 1 \\
\text { NO ACTION }\end{array}$ & $\begin{array}{c}\text { ALTERNATIVE } 2 \\
\text { ADMINISTRATIVE CONTROLS }\end{array}$ & $\begin{array}{l}\text { ALTERNATIVE } 3 \\
\text { CLEAN CLOSURE }\end{array}$ & $\begin{array}{l}\text { ALTERNATIVE } 4 \\
\text { BIOREMEDIATION }\end{array}$ \\
\hline $\begin{array}{l}\text { Short-Term Reliability and } \\
\text { Effectiveness }\end{array}$ & $\begin{array}{l}\text { Does not institute any controls to } \\
\text { mitigate current or short-term } \\
\text { risks }\end{array}$ & $\begin{array}{l}\text { - Potential for worker exposure } \\
\text { during cover construction at } \\
\text { exposed impacted areas and } \\
\text { areas of excavation into } \\
\text { impacted zones } \\
\text { - Public advised by warnings } \\
\text { posted in areas restricting } \\
\text { surface or subsurface } \\
\text { disturbance } \\
\text { - Accident potential associated } \\
\text { with heavy equipment }\end{array}$ & $\begin{array}{l}\text { - Potential for worker exposure } \\
\text { during excavation, transportation, } \\
\text { and disposal } \\
\text { - Potential for public exposure and } \\
\text { COC release associated with } \\
\text { transportation accident } \\
\text { - Accident potential associated } \\
\text { with heavy equipment }\end{array}$ & $\begin{array}{l}\text { - Potential for worker exposure } \\
\text { during excavation/drilling } \\
\text { activities to introduce } \\
\text { innoculants or during } \\
\text { landfarming activities } \\
\text { - Accident potential associated } \\
\text { with heavy equipment }\end{array}$ \\
\hline $\begin{array}{l}\text { Reduction of Toxicity, } \\
\text { Mobility, and/or Volume }\end{array}$ & $\begin{array}{l}\text { - Natural attenuation of petroleum } \\
\text { hydrocarbons may reduce } \\
\text { toxicity, mobility, and volume } \\
\text { over time }\end{array}$ & $\begin{array}{l}\text { - Natural attenuation of petroleum } \\
\text { hydrocarbons may reduce } \\
\text { toxicity, mobility, and volume } \\
\text { over time } \\
\text { - Adequate, low permeability } \\
\text { cover reduces mobility to } \\
\text { groundwater } \\
\text { - Cover maintenance ensures } \\
\text { integrity }\end{array}$ & $\begin{array}{l}\text { - Natural attenuation of petroleum } \\
\text { hydrocarbons reduces toxicity, } \\
\text { mobility, and volume over time } \\
\text { - Toxicity, mobility, and volume } \\
\text { eliminated at the site but may not } \\
\text { be reduced at place of disposal }\end{array}$ & $\begin{array}{l}\text { Natural attenuation of petroleum } \\
\text { hydrocarbons reduces toxicity, } \\
\text { mobility, and volume over time }\end{array}$ \\
\hline $\begin{array}{l}\text { Long-Term Reliability and } \\
\text { Effectiveness }\end{array}$ & $\begin{array}{l}\text { - Risk reduction associated with } \\
\text { natural attenuation of COCs }\end{array}$ & $\begin{array}{l}\text { - Small residual risk associated } \\
\text { with COC levels } \\
\text { - Risk reduction associated with } \\
\text { partial removal and natural } \\
\text { attenuation of COCs } \\
\text { - Controls inadvertent intrusion } \\
\text { - Monitoring and maintenance of } \\
\text { cover and posting are required }\end{array}$ & - Risk is removed & $\begin{array}{l}\text { - Risk reduction associated with } \\
\text { the degradation of COCs } \\
\text { - Monitoring and maintenance } \\
\text { required until COCs are below } \\
\text { media cleanup standards }\end{array}$ \\
\hline
\end{tabular}


Table 3-2

Detailed Remedy Selection Decision Factors Evaluation of Alternatives for CASs Exceeding Action Levels

\section{(Page 2 of 2)}

\begin{tabular}{|c|c|c|c|c|}
\hline $\begin{array}{l}\text { REMEDY SELECTION } \\
\text { DECISION FACTORS } \\
\text { EVALUATION CRITERIA }\end{array}$ & $\begin{array}{l}\text { ALTERNATIVE } 1 \\
\text { NO ACTION }\end{array}$ & $\begin{array}{c}\text { ALTERNATIVE } 2 \\
\text { ADMINISTRATIVE CONTROLS }\end{array}$ & $\begin{array}{l}\text { ALTERNATIVE } 3 \\
\text { CLEAN CLOSURE }\end{array}$ & $\begin{array}{l}\text { ALTERNATIVE } 4 \\
\text { BIOREMEDIATION }\end{array}$ \\
\hline Feasibility & $\begin{array}{l}\text { - Implementable } \\
\text { - Not feasible because the media } \\
\text { cleanup standard is not met }\end{array}$ & $\begin{array}{l}\text { - Implementable } \\
\text { - Coordination of all entities is } \\
\text { necessary to ensure } \\
\text { compliance }\end{array}$ & $\begin{array}{l}\text { - Implementable } \\
\text { - Disposal of large volume of } \\
\text { waste is required } \\
\text { - Coordination of all entities is } \\
\text { necessary to ensure compliance }\end{array}$ & $\begin{array}{l}\text { - Implementable; however, } \\
\text { reduction of COC concentration } \\
\text { to media cleanup standards } \\
\text { may not be completed by the } \\
\text { FFACO closure schedule } \\
\text { - Coordination of all entities is } \\
\text { necessary to ensure } \\
\text { compliance }\end{array}$ \\
\hline Cost & $\begin{array}{l}\text { - No cost associated with this } \\
\text { option }\end{array}$ & $\begin{array}{l}\text { - Least expensive of the options } \\
\text { other than no action. } \\
\text { Costs for administrative controls } \\
\text { with engineered covers are } \\
\text { comparable to the landfarming } \\
\text { costs. }\end{array}$ & $\begin{array}{l}\text { - Most expensive of the proposed } \\
\text { options. }\end{array}$ & $\begin{array}{l}\text { - Costs fall between the costs for } \\
\text { Alternatives } 2 \text { and } 3 \text {. } \\
\text { - For most of the sites the costs } \\
\text { for in situ bioremediation are } \\
\text { comparable to the low-range } \\
\text { costs for clean closure. } \\
\text { - Both the landfarming and in situ } \\
\text { bioremediation costs are } \\
\text { several times higher than the } \\
\text { costs for clean closure with } \\
\text { disposal at the CMP. }\end{array}$ \\
\hline
\end{tabular}


Revision: 1

Date: $04 / 05 / 99$

Page 37 of 57

Table 3-3 presents a summary of the comparative evaluations for corrective action alternatives for sites exceeding the TPH $100 \mathrm{mg} / \mathrm{kg}$ action level. Table C-1, located in Appendix C, provides a more detailed analysis of the comparative evaluation for each corrective action alternative. Cost estimate details are provided in Appendix A. 


\section{Table 3-3 \\ Comparative Evaluation of Corrective Action Alternatives for Sites Exceeding Action Levels}

\section{(Page 1 of 8 )}

$\checkmark$ indicates that the listed alternative meets the evaluation criteria, $2 \mathrm{~A}=$ site postings, $2 \mathrm{~B}=$ partial excavation with engineered backfill, $2 \mathrm{C}=\mathrm{engineered}$ cover,

3A = Disposal at the NTS, 3B = Disposal at a private facility, 3C = Disposal at the central mud pit, 4A = landfarming, 4B = in situ

\begin{tabular}{|c|c|c|c|c|c|c|c|c|c|}
\hline \multirow{2}{*}{$\begin{array}{l}\text { UC-1 Contamination Site } \\
\text { CAS 58-09-01 Central Mud Pit } \\
\text { Evaluation Criteria }\end{array}$} & \multirow[t]{2}{*}{$\begin{array}{c}\text { Alternative } 1 \\
\text { No Action }\end{array}$} & \multicolumn{3}{|c|}{$\begin{array}{c}\text { Alternative } 2 \\
\text { Administrative } \\
\text { Controls }\end{array}$} & \multicolumn{3}{|c|}{$\begin{array}{c}\text { Alternative } 3 \\
\text { Clean Closure }\end{array}$} & \multicolumn{2}{|c|}{$\begin{array}{c}\text { Alternative } 4 \\
\text { Bioremediation }\end{array}$} \\
\hline & & $\overline{2 A}$ & $2 \mathrm{~B}$ & $2 \mathrm{C}$ & $3 \mathrm{~A}$ & $3 \mathrm{~B}$ & $3 \mathrm{C}$ & $4 \mathrm{~A}$ & $4 \mathrm{~B}$ \\
\hline Protection of Human Health and the Environment & & $\checkmark$ & $\checkmark$ & $\checkmark$ & $\checkmark$ & $\checkmark$ & $\checkmark$ & $\checkmark$ & $\checkmark$ \\
\hline Compliance with Media Cleanup Standards & & $\checkmark$ & $\checkmark$ & $\checkmark$ & $\checkmark$ & $\checkmark$ & $\checkmark$ & $\checkmark$ & $\checkmark$ \\
\hline Control the Source(s) of the Release & & & $\checkmark$ & $\checkmark$ & $\checkmark$ & $\checkmark$ & $\checkmark$ & $\checkmark$ & $\checkmark$ \\
\hline Comply with Applicable Federal, State, and Local Standards for Waste Management & $\checkmark$ & $\checkmark$ & $\checkmark$ & $\checkmark$ & $\checkmark$ & $\checkmark$ & $\checkmark$ & $\checkmark$ & $\checkmark$ \\
\hline Short-Term Reliability and Effectiveness & & $\checkmark$ & $\checkmark$ & $\checkmark$ & $\checkmark$ & $\checkmark$ & $\checkmark$ & $\checkmark$ & $\checkmark$ \\
\hline Reduction of Toxicity, Mobility, and/or Volume & $\checkmark$ & $\checkmark$ & $\checkmark$ & $\checkmark$ & $\checkmark$ & $\checkmark$ & $\checkmark$ & $\checkmark$ & $\checkmark$ \\
\hline Long-Term Reliability and Effectiveness & & & $\checkmark$ & $\checkmark$ & $\checkmark$ & $\checkmark$ & $\checkmark$ & $\checkmark$ & $\checkmark$ \\
\hline Feasibility & & $\checkmark$ & $\checkmark$ & $\checkmark$ & $\checkmark$ & $\checkmark$ & $\checkmark$ & & \\
\hline \multicolumn{10}{|l|}{ Cost (For cost comparison see Appendix C.) } \\
\hline \multirow{2}{*}{$\begin{array}{l}\text { UC-1 Contamination Site } \\
\text { CAS 58-09-02 Mud Pit U1A } \\
\text { Evaluation Criteria }\end{array}$} & \multirow[t]{2}{*}{$\begin{array}{c}\text { Alternative } 1 \\
\text { No Action }\end{array}$} & \multicolumn{3}{|c|}{$\begin{array}{c}\text { Alternative } 2 \\
\text { Administrative } \\
\text { Controls }\end{array}$} & \multicolumn{3}{|c|}{$\begin{array}{c}\text { Alternative } 3 \\
\text { Clean Closure }\end{array}$} & \multicolumn{2}{|c|}{$\begin{array}{c}\text { Alternative } 4 \\
\text { Bioremediation }\end{array}$} \\
\hline & & $\overline{2 A}$ & $2 \mathrm{~B}$ & $2 \mathrm{C}$ & $\overline{3 \mathrm{~A}}$ & $3 \mathrm{~B}$ & $3 \mathrm{C}$ & $4 \mathrm{~A}$ & $4 \mathrm{~B}$ \\
\hline Protection of Human Health and the Environment & & $\checkmark$ & $\checkmark$ & $\checkmark$ & $\checkmark$ & $\checkmark$ & $\checkmark$ & $\checkmark$ & $\checkmark$ \\
\hline Compliance with Media Cleanup Standards & & $\checkmark$ & $\checkmark$ & $\checkmark$ & $\checkmark$ & $\checkmark$ & $\checkmark$ & $\checkmark$ & $\checkmark$ \\
\hline Control the Source(s) of the Release & & & $\checkmark$ & $\checkmark$ & $\checkmark$ & $\checkmark$ & $\checkmark$ & $\checkmark$ & $\checkmark$ \\
\hline Comply with Applicable Federal, State, and Local Standards for Waste Management & $\checkmark$ & $\checkmark$ & $\checkmark$ & $\checkmark$ & $\checkmark$ & $\checkmark$ & $\checkmark$ & $\checkmark$ & $\checkmark$ \\
\hline Short-Term Reliability and Effectiveness & & $\checkmark$ & $\checkmark$ & $\checkmark$ & $\checkmark$ & $\checkmark$ & $\checkmark$ & $\checkmark$ & $\checkmark$ \\
\hline Reduction of Toxicity, Mobility, and/or Volume & $\checkmark$ & $\checkmark$ & $\checkmark$ & $\checkmark$ & $\checkmark$ & $\checkmark$ & $\checkmark$ & $\checkmark$ & $\checkmark$ \\
\hline Long-Term Reliability and Effectiveness & & $\checkmark$ & $\checkmark$ & $\checkmark$ & $\checkmark$ & $\checkmark$ & $\checkmark$ & $\checkmark$ & $\checkmark$ \\
\hline Feasibility & & $\checkmark$ & $\checkmark$ & $\checkmark$ & $\checkmark$ & $\checkmark$ & $\checkmark$ & $\checkmark$ & $\checkmark$ \\
\hline Cost (For cost comparison see Appendix C.) & & & & & & & & & \\
\hline
\end{tabular}




\section{Table 3-3}

\section{Comparative Evaluation of Corrective Action Alternatives for Sites Exceeding Action Levels}

\section{(Page 2 of 8 )}

$\checkmark$ indicates that the listed alternative meets the evaluation criteria, $2 \mathrm{~A}=$ site postings, $2 \mathrm{~B}=$ partial excavation with engineered backfill, $2 \mathrm{C}=$ engineered cover,

3A = Disposal at the NTS, 3B = Disposal at a private facility, 3C = Disposal at the central mud pit, 4A = landfarming, 4B = in situ

\begin{tabular}{|c|c|c|c|c|c|c|c|c|c|}
\hline \multirow{2}{*}{$\begin{array}{l}\text { UC-1 Contamination Site } \\
\text { CAS 58-09-05 Mud Pit U1E } \\
\text { Evaluation Criteria }\end{array}$} & \multirow[t]{2}{*}{$\begin{array}{l}\text { Alternative } 1 \\
\text { No Action }\end{array}$} & \multicolumn{3}{|c|}{$\begin{array}{c}\text { Alternative } 2 \\
\text { Administrative } \\
\text { Controls } \\
\end{array}$} & \multicolumn{3}{|c|}{$\begin{array}{l}\text { Alternative } 3 \\
\text { Clean Closure }\end{array}$} & \multicolumn{2}{|c|}{$\begin{array}{c}\text { Alternative } 4 \\
\text { Bioremediation }\end{array}$} \\
\hline & & $2 \mathrm{~A}$ & $2 \mathrm{~B}$ & $2 \mathrm{C}$ & $3 \mathrm{~A}$ & $3 \mathrm{~B}$ & $3 \mathrm{C}$ & \multicolumn{2}{|c|}{ 4A 4B } \\
\hline Protection of Human Health and the Environment & & $\checkmark$ & $\checkmark$ & $\checkmark$ & $\checkmark$ & $\checkmark$ & $\checkmark$ & $\checkmark$ & $\checkmark$ \\
\hline Compliance with Media Cleanup Standards & & $\checkmark$ & $\checkmark$ & $\checkmark$ & $\checkmark$ & $\checkmark$ & $\checkmark$ & $\checkmark$ & $\checkmark$ \\
\hline Control the Source(s) of the Release & & & $\checkmark$ & $\checkmark$ & $\checkmark$ & $\checkmark$ & $\checkmark$ & $\checkmark$ & $\checkmark$ \\
\hline Comply with Applicable Federal, State, and Local Standards for Waste Management & $\checkmark$ & $\checkmark$ & $\checkmark$ & $\checkmark$ & $\checkmark$ & $\checkmark$ & $\checkmark$ & $\checkmark$ & $\checkmark$ \\
\hline Short-Term Reliability and Effectiveness & & $\checkmark$ & $\checkmark$ & $\checkmark$ & $\checkmark$ & $\checkmark$ & $\checkmark$ & $\checkmark$ & $\checkmark$ \\
\hline Reduction of Toxicity, Mobility, and/or Volume & $\checkmark$ & $\checkmark$ & $\checkmark$ & $\checkmark$ & $\checkmark$ & $\checkmark$ & $\checkmark$ & $\checkmark$ & $\checkmark$ \\
\hline Long-Term Reliability and Effectiveness & & $\checkmark$ & $\checkmark$ & $\checkmark$ & $\checkmark$ & $\checkmark$ & $\checkmark$ & $\checkmark$ & $\checkmark$ \\
\hline Feasibility & & $\checkmark$ & $\checkmark$ & $\checkmark$ & $\checkmark$ & $\checkmark$ & $\checkmark$ & $\checkmark$ & $\checkmark$ \\
\hline \multicolumn{10}{|l|}{ Cost (For cost comparison see Appendix C.) } \\
\hline \multirow{2}{*}{$\begin{array}{l}\text { UC-1 Contamination Site } \\
\text { CAS 58-10-03 Shaker Pad Area U1S } \\
\text { Evaluation Criteria }\end{array}$} & \multirow[t]{2}{*}{$\begin{array}{c}\text { Alternative } 1 \\
\text { No Action }\end{array}$} & \multicolumn{3}{|c|}{$\begin{array}{c}\text { Alternative } 2 \\
\text { Administrative } \\
\text { Controls } \\
\end{array}$} & \multicolumn{3}{|c|}{$\begin{array}{l}\text { Alternative } 3 \\
\text { Clean Closure }\end{array}$} & \multicolumn{2}{|c|}{$\begin{array}{c}\text { Alternative } 4 \\
\text { Bioremediation }\end{array}$} \\
\hline & & $2 \mathrm{~A}$ & $2 \mathrm{~B}$ & $2 \mathrm{C}$ & $3 \mathrm{~A}$ & $3 \mathrm{~B}$ & $3 \mathrm{C}$ & $4 \mathrm{~A}$ & $4 \mathrm{~B}$ \\
\hline Protection of Human Health and the Environment & & $\checkmark$ & $\checkmark$ & $\checkmark$ & $\checkmark$ & $\checkmark$ & $\checkmark$ & $\checkmark$ & $\checkmark$ \\
\hline Compliance with Media Cleanup Standards & & $\checkmark$ & $\checkmark$ & $\checkmark$ & $\checkmark$ & $\checkmark$ & $\checkmark$ & $\checkmark$ & $\checkmark$ \\
\hline Control the Source(s) of the Release & & & $\checkmark$ & $\checkmark$ & $\checkmark$ & $\checkmark$ & $\checkmark$ & $\checkmark$ & $\checkmark$ \\
\hline Comply with Applicable Federal, State, and Local Standards for Waste Management & $\checkmark$ & $\checkmark$ & $\checkmark$ & $\checkmark$ & $\checkmark$ & $\checkmark$ & $\checkmark$ & $\checkmark$ & $\checkmark$ \\
\hline Short-Term Reliability and Effectiveness & & $\checkmark$ & $\checkmark$ & $\checkmark$ & $\checkmark$ & $\checkmark$ & $\checkmark$ & $\checkmark$ & $\checkmark$ \\
\hline Reduction of Toxicity, Mobility, and/or Volume & $\checkmark$ & $\checkmark$ & $\checkmark$ & $\checkmark$ & $\checkmark$ & $\checkmark$ & $\checkmark$ & $\checkmark$ & $\checkmark$ \\
\hline Long-Term Reliability and Effectiveness & & $\checkmark$ & $\checkmark$ & $\checkmark$ & $\checkmark$ & $\checkmark$ & $\checkmark$ & $\checkmark$ & $\checkmark$ \\
\hline Feasibility & & $\checkmark$ & $\checkmark$ & $\checkmark$ & $\checkmark$ & $\checkmark$ & $\checkmark$ & $\checkmark$ & $\checkmark$ \\
\hline Cost (For cost comparison see Appendix C.) & & & & & & & & & \\
\hline
\end{tabular}




\section{Comparative Evaluation of Corrective Action Alternatives for Sites Exceeding Action Levels}

\section{Table 3-3}

(Page 3 of 8 )

$\checkmark$ indicates that the listed alternative meets the evaluation criteria, $2 \mathrm{~A}=$ site postings, $2 \mathrm{~B}=$ partial excavation with engineered backfill, $2 \mathrm{C}=$ engineered cover,

3A = Disposal at the NTS, 3B $=$ Disposal at a private facility, $3 \mathrm{C}=$ Disposal at the central mud pit, 4A $=$ landfarming, 4B $=$ in situ

\begin{tabular}{|c|c|c|c|c|c|c|c|c|c|}
\hline \multirow{2}{*}{$\begin{array}{l}\text { UC-1 Contamination Site } \\
\text { CAS 58-44-06 Borrow Pit U1Y } \\
\text { Evaluation Criteria }\end{array}$} & \multirow[t]{2}{*}{$\begin{array}{l}\text { Alternative } 1 \\
\text { No Action }\end{array}$} & \multicolumn{3}{|c|}{$\begin{array}{l}\text { Alternative } 2 \\
\text { Administrative } \\
\text { Controls }\end{array}$} & \multicolumn{3}{|c|}{$\begin{array}{l}\text { Alternative } 3 \\
\text { Clean Closure }\end{array}$} & \multicolumn{2}{|c|}{$\begin{array}{c}\text { Alternative } 4 \\
\text { Bioremediation }\end{array}$} \\
\hline & & $2 \mathrm{~A}$ & $2 \mathrm{~B}$ & $2 \mathrm{C}$ & $3 \mathrm{~A}$ & $3 \mathrm{~B}$ & $3 \mathrm{C}$ & $4 \mathrm{~A}$ & $4 \mathrm{~B}$ \\
\hline Protection of Human Health and the Environment & & $\checkmark$ & $\checkmark$ & $\checkmark$ & $\checkmark$ & $\checkmark$ & $\checkmark$ & $\checkmark$ & $\checkmark$ \\
\hline Compliance with Media Cleanup Standards & & $\checkmark$ & $\checkmark$ & $\checkmark$ & $\checkmark$ & $\checkmark$ & $\checkmark$ & $\checkmark$ & $\checkmark$ \\
\hline Control the Source(s) of the Release & & & $\checkmark$ & $\checkmark$ & $\checkmark$ & $\checkmark$ & $\checkmark$ & $\checkmark$ & $\checkmark$ \\
\hline Comply with Applicable Federal, State, and Local Standards for Waste Management & $\checkmark$ & $\checkmark$ & $\checkmark$ & $\checkmark$ & $\checkmark$ & $\checkmark$ & $\checkmark$ & $\checkmark$ & $\checkmark$ \\
\hline Short-Term Reliability and Effectiveness & & $\checkmark$ & $\checkmark$ & $\checkmark$ & $\checkmark$ & $\checkmark$ & $\checkmark$ & $\checkmark$ & $\checkmark$ \\
\hline Reduction of Toxicity, Mobility, and/or Volume & $\checkmark$ & $\checkmark$ & $\checkmark$ & $\checkmark$ & $\checkmark$ & $\checkmark$ & $\checkmark$ & $\checkmark$ & $\checkmark$ \\
\hline Long-Term Reliability and Effectiveness & & $\checkmark$ & $\checkmark$ & $\checkmark$ & $\checkmark$ & $\checkmark$ & $\checkmark$ & $\checkmark$ & $\checkmark$ \\
\hline Feasibility & & $\checkmark$ & $\checkmark$ & $\checkmark$ & $\checkmark$ & $\checkmark$ & $\checkmark$ & $\checkmark$ & $\checkmark$ \\
\hline Cost (For cost comparison see Appendix C.) & & & & & & & & & \\
\hline
\end{tabular}




\section{Table 3-3}

\section{Comparative Evaluation of Corrective Action Alternatives for Sites Exceeding Action Levels}

\section{(Page 4 of 8 )}

$\checkmark$ indicates that the listed alternative meets the evaluation criteria, $2 \mathrm{~A}=$ site postings, $2 \mathrm{~B}=$ partial excavation with engineered backfill, $2 \mathrm{C}=$ engineered cover,

3A = Disposal at the NTS, 3B = Disposal at a private facility, 3C = Disposal at the central mud pit, 4A = landfarming, 4B = in situ

\begin{tabular}{|c|c|c|c|c|c|c|c|c|c|}
\hline \multirow{2}{*}{$\begin{array}{l}\text { UC-3 Contamination Site } \\
\text { CAS 58-09-06 Mud Pit U3E } \\
\text { Evaluation Criteria }\end{array}$} & \multirow[t]{2}{*}{$\begin{array}{c}\text { Alternative } 1 \\
\text { No Action }\end{array}$} & \multicolumn{3}{|c|}{$\begin{array}{l}\text { Alternative } 2 \\
\text { Administrative } \\
\text { Controls }\end{array}$} & \multicolumn{3}{|c|}{$\begin{array}{l}\text { Alternative } 3 \\
\text { Clean Closure }\end{array}$} & \multicolumn{2}{|c|}{$\begin{array}{c}\text { Alternative } 4 \\
\text { Bioremediation }\end{array}$} \\
\hline & & $\overline{2 A}$ & $2 \mathrm{~B}$ & $2 \mathrm{C}$ & $\overline{3 \mathrm{~A}}$ & $3 \mathrm{~B}$ & $3 \mathrm{C}$ & $4 \mathrm{~A}$ & $4 \mathrm{~B}$ \\
\hline Protection of Human Health and the Environment & & $\checkmark$ & $\checkmark$ & $\checkmark$ & $\checkmark$ & $\checkmark$ & $\checkmark$ & $\checkmark$ & $\checkmark$ \\
\hline Compliance with Media Cleanup Standards & & $\checkmark$ & $\checkmark$ & $\checkmark$ & $\checkmark$ & $\checkmark$ & $\checkmark$ & $\checkmark$ & $\checkmark$ \\
\hline Control the Source(s) of the Release & & & $\checkmark$ & $\checkmark$ & $\checkmark$ & $\checkmark$ & $\checkmark$ & $\checkmark$ & $\checkmark$ \\
\hline Comply with Applicable Federal, State, and Local Standards for Waste Management & $\checkmark$ & $\checkmark$ & $\checkmark$ & $\checkmark$ & $\checkmark$ & $\checkmark$ & $\checkmark$ & $\checkmark$ & $\checkmark$ \\
\hline Short-Term Reliability and Effectiveness & & $\checkmark$ & $\checkmark$ & $\checkmark$ & $\checkmark$ & $\checkmark$ & $\checkmark$ & $\checkmark$ & $\checkmark$ \\
\hline Reduction of Toxicity, Mobility, and/or Volume & $\checkmark$ & $\checkmark$ & $\checkmark$ & $\checkmark$ & $\checkmark$ & $\checkmark$ & $\checkmark$ & $\checkmark$ & $\checkmark$ \\
\hline Long-Term Reliability and Effectiveness & & $\checkmark$ & $\checkmark$ & $\checkmark$ & $\checkmark$ & $\checkmark$ & $\checkmark$ & $\checkmark$ & $\checkmark$ \\
\hline Feasibility & & $\checkmark$ & $\checkmark$ & $\checkmark$ & $\checkmark$ & $\checkmark$ & $\checkmark$ & $\checkmark$ & $\checkmark$ \\
\hline \multicolumn{10}{|l|}{ Cost (For cost comparison see Appendix C.) } \\
\hline \multirow{2}{*}{$\begin{array}{l}\text { UC-3 Contamination Site } \\
\text { CAS 58-10-01 Shaker Pad Area (U3S) } \\
\text { Evaluation Criteria }\end{array}$} & \multirow[t]{2}{*}{$\begin{array}{c}\text { Alternative } 1 \\
\text { No Action }\end{array}$} & \multicolumn{3}{|c|}{$\begin{array}{c}\text { Alternative 2 } \\
\text { Administrative } \\
\text { Controls } \\
\end{array}$} & \multicolumn{3}{|c|}{$\begin{array}{l}\text { Alternative } 3 \\
\text { Clean Closure }\end{array}$} & \multicolumn{2}{|c|}{$\begin{array}{c}\text { Alternative } 4 \\
\text { Bioremediation }\end{array}$} \\
\hline & & $2 \mathrm{~A}$ & $2 \mathrm{~B}$ & $2 \mathrm{C}$ & $3 \mathrm{~A}$ & $3 \mathrm{~B}$ & $3 \mathrm{C}$ & $4 \mathrm{~A}$ & $4 \mathrm{~B}$ \\
\hline Protection of Human Health and the Environment & & $\checkmark$ & $\checkmark$ & $\checkmark$ & $\checkmark$ & $\checkmark$ & $\checkmark$ & $\checkmark$ & $\checkmark$ \\
\hline Compliance with Media Cleanup Standards & & $\checkmark$ & $\checkmark$ & $\checkmark$ & $\checkmark$ & $\checkmark$ & $\checkmark$ & $\checkmark$ & $\checkmark$ \\
\hline Control the Source(s) of the Release & & & $\checkmark$ & $\checkmark$ & $\checkmark$ & $\checkmark$ & $\checkmark$ & $\checkmark$ & $\checkmark$ \\
\hline Comply with Applicable Federal, State, and Local Standards for Waste Management & $\checkmark$ & $\checkmark$ & $\checkmark$ & $\checkmark$ & $\checkmark$ & $\checkmark$ & $\checkmark$ & $\checkmark$ & $\checkmark$ \\
\hline Short-Term Reliability and Effectiveness & & $\checkmark$ & $\checkmark$ & $\checkmark$ & $\checkmark$ & $\checkmark$ & $\checkmark$ & $\checkmark$ & $\checkmark$ \\
\hline Reduction of Toxicity, Mobility, and/or Volume & $\checkmark$ & $\checkmark$ & $\checkmark$ & $\checkmark$ & $\checkmark$ & $\checkmark$ & $\checkmark$ & $\checkmark$ & $\checkmark$ \\
\hline Long-Term Reliability and Effectiveness & & $\checkmark$ & $\checkmark$ & $\checkmark$ & $\checkmark$ & $\checkmark$ & $\checkmark$ & $\checkmark$ & $\checkmark$ \\
\hline Feasibility & & $\checkmark$ & $\checkmark$ & $\checkmark$ & $\checkmark$ & $\checkmark$ & $\checkmark$ & $\checkmark$ & $\checkmark$ \\
\hline Cost (For cost comparison see Appendix C.) & & & & & & & & & \\
\hline
\end{tabular}




\section{Table 3-3}

\section{Comparative Evaluation of Corrective Action Alternatives for Sites Exceeding Action Levels}

\section{(Page 5 of 8 )}

$\checkmark$ indicates that the listed alternative meets the evaluation criteria, $2 \mathrm{~A}=$ site postings, $2 \mathrm{~B}=$ partial excavation with engineered backfill, $2 \mathrm{C}=$ engineered cover,

3A = Disposal at the NTS, 3B = Disposal at a private facility, 3C = Disposal at the central mud pit, 4A = landfarming, 4B = in situ

\begin{tabular}{|c|c|c|c|c|c|c|c|c|c|}
\hline \multirow{2}{*}{$\begin{array}{l}\text { UC-3 Contamination Site } \\
\text { CAS 58-25-01 Spill Southern Outlier (U3E) } \\
\text { Evaluation Criteria }\end{array}$} & \multirow[t]{2}{*}{$\begin{array}{c}\text { Alternative } 1 \\
\text { No Action }\end{array}$} & \multicolumn{3}{|c|}{$\begin{array}{l}\text { Alternative } 2 \\
\text { Administrative } \\
\text { Controls }\end{array}$} & \multicolumn{3}{|c|}{$\begin{array}{l}\text { Alternative } 3 \\
\text { Clean Closure }\end{array}$} & \multicolumn{2}{|c|}{$\begin{array}{c}\text { Alternative } 4 \\
\text { Bioremediation }\end{array}$} \\
\hline & & $\overline{2 A}$ & $2 \mathrm{~B}$ & $2 \mathrm{C}$ & $\overline{3 \mathrm{~A}}$ & $3 \mathrm{~B}$ & $3 \mathrm{C}$ & $4 \mathrm{~A}$ & $4 \mathrm{~B}$ \\
\hline Protection of Human Health and the Environment & & $\checkmark$ & $\checkmark$ & $\checkmark$ & $\checkmark$ & $\checkmark$ & $\checkmark$ & $\checkmark$ & $\checkmark$ \\
\hline Compliance with Media Cleanup Standards & & $\checkmark$ & $\checkmark$ & $\checkmark$ & $\checkmark$ & $\checkmark$ & $\checkmark$ & $\checkmark$ & $\checkmark$ \\
\hline Control the Source(s) of the Release & & & $\checkmark$ & $\checkmark$ & $\checkmark$ & $\checkmark$ & $\checkmark$ & $\checkmark$ & $\checkmark$ \\
\hline Comply with Applicable Federal, State, and Local Standards for Waste Management & $\checkmark$ & $\checkmark$ & $\checkmark$ & $\checkmark$ & $\checkmark$ & $\checkmark$ & $\checkmark$ & $\checkmark$ & $\checkmark$ \\
\hline Short-Term Reliability and Effectiveness & & $\checkmark$ & $\checkmark$ & $\checkmark$ & $\checkmark$ & $\checkmark$ & $\checkmark$ & $\checkmark$ & $\checkmark$ \\
\hline Reduction of Toxicity, Mobility, and/or Volume & $\checkmark$ & $\checkmark$ & $\checkmark$ & $\checkmark$ & $\checkmark$ & $\checkmark$ & $\checkmark$ & $\checkmark$ & $\checkmark$ \\
\hline Long-Term Reliability and Effectiveness & & $\checkmark$ & $\checkmark$ & $\checkmark$ & $\checkmark$ & $\checkmark$ & $\checkmark$ & $\checkmark$ & $\checkmark$ \\
\hline Feasibility & & $\checkmark$ & $\checkmark$ & $\checkmark$ & $\checkmark$ & $\checkmark$ & $\checkmark$ & $\checkmark$ & $\checkmark$ \\
\hline \multicolumn{10}{|l|}{ Cost (For cost comparison see Appendix C.) } \\
\hline \multirow{2}{*}{$\begin{array}{l}\text { UC-3 Contamination Site } \\
\text { CAS 58-44-03 Drill Mud/Grout Spill (U3Z) } \\
\text { Evaluation Criteria }\end{array}$} & \multirow[t]{2}{*}{$\begin{array}{c}\text { Alternative } 1 \\
\text { No Action }\end{array}$} & \multicolumn{3}{|c|}{$\begin{array}{c}\text { Alternative 2 } \\
\text { Administrative } \\
\text { Controls } \\
\end{array}$} & \multicolumn{3}{|c|}{$\begin{array}{l}\text { Alternative } 3 \\
\text { Clean Closure }\end{array}$} & \multicolumn{2}{|c|}{$\begin{array}{c}\text { Alternative } 4 \\
\text { Bioremediation }\end{array}$} \\
\hline & & $2 \mathrm{~A}$ & $2 \mathrm{~B}$ & $2 \mathrm{C}$ & $3 \mathrm{~A}$ & $3 \mathrm{~B}$ & $3 \mathrm{C}$ & $4 \mathrm{~A}$ & $4 \mathrm{~B}$ \\
\hline Protection of Human Health and the Environment & & $\checkmark$ & $\checkmark$ & $\checkmark$ & $\checkmark$ & $\checkmark$ & $\checkmark$ & $\checkmark$ & $\checkmark$ \\
\hline Compliance with Media Cleanup Standards & & $\checkmark$ & $\checkmark$ & $\checkmark$ & $\checkmark$ & $\checkmark$ & $\checkmark$ & $\checkmark$ & $\checkmark$ \\
\hline Control the Source(s) of the Release & & & $\checkmark$ & $\checkmark$ & $\checkmark$ & $\checkmark$ & $\checkmark$ & $\checkmark$ & $\checkmark$ \\
\hline Comply with Applicable Federal, State, and Local Standards for Waste Management & $\checkmark$ & $\checkmark$ & $\checkmark$ & $\checkmark$ & $\checkmark$ & $\checkmark$ & $\checkmark$ & $\checkmark$ & $\checkmark$ \\
\hline Short-Term Reliability and Effectiveness & & $\checkmark$ & $\checkmark$ & $\checkmark$ & $\checkmark$ & $\checkmark$ & $\checkmark$ & $\checkmark$ & $\checkmark$ \\
\hline Reduction of Toxicity, Mobility, and/or Volume & $\checkmark$ & $\checkmark$ & $\checkmark$ & $\checkmark$ & $\checkmark$ & $\checkmark$ & $\checkmark$ & $\checkmark$ & $\checkmark$ \\
\hline Long-Term Reliability and Effectiveness & & $\checkmark$ & $\checkmark$ & $\checkmark$ & $\checkmark$ & $\checkmark$ & $\checkmark$ & $\checkmark$ & $\checkmark$ \\
\hline Feasibility & & $\checkmark$ & $\checkmark$ & $\checkmark$ & $\checkmark$ & $\checkmark$ & $\checkmark$ & $\checkmark$ & $\checkmark$ \\
\hline Cost (For cost comparison see Appendix C.) & & & & & & & & & \\
\hline
\end{tabular}




\section{Comparative Evaluation of Corrective Action Alternatives for Sites Exceeding Action Levels}

\section{Table 3-3}

(Page 6 of 8 )

$\checkmark$ indicates that the listed alternative meets the evaluation criteria, $2 \mathrm{~A}=$ site postings, $2 \mathrm{~B}=$ partial excavation with engineered backfill, $2 \mathrm{C}=$ engineered cover,

3A = Disposal at the NTS, 3B $=$ Disposal at a private facility, $3 \mathrm{C}=$ Disposal at the central mud pit, 4A $=$ landfarming, 4B $=$ in situ

\begin{tabular}{|c|c|c|c|c|c|c|c|c|c|}
\hline \multirow{2}{*}{$\begin{array}{l}\text { UC-4 Contamination Site } \\
\text { CAS 58-09-03 Mud Pit U4A, U4B, U4C, U4D } \\
\text { Evaluation Criteria }\end{array}$} & \multirow[t]{2}{*}{$\begin{array}{l}\text { Alternative } 1 \\
\text { No Action }\end{array}$} & \multicolumn{3}{|c|}{$\begin{array}{l}\text { Alternative } 2 \\
\text { Administrative } \\
\text { Controls }\end{array}$} & \multicolumn{3}{|c|}{$\begin{array}{l}\text { Alternative } 3 \\
\text { Clean Closure }\end{array}$} & \multicolumn{2}{|c|}{$\begin{array}{c}\text { Alternative } 4 \\
\text { Bioremediation }\end{array}$} \\
\hline & & $2 \mathrm{~A}$ & $2 \mathrm{~B}$ & $2 \mathrm{C}$ & $3 \mathrm{~A}$ & $3 \mathrm{~B}$ & $3 \mathrm{C}$ & $4 \mathrm{~A}$ & $4 \mathrm{~B}$ \\
\hline Protection of Human Health and the Environment & & $\checkmark$ & $\checkmark$ & $\checkmark$ & $\checkmark$ & $\checkmark$ & $\checkmark$ & $\checkmark$ & $\checkmark$ \\
\hline Compliance with Media Cleanup Standards & & $\checkmark$ & $\checkmark$ & $\checkmark$ & $\checkmark$ & $\checkmark$ & $\checkmark$ & $\checkmark$ & $\checkmark$ \\
\hline Control the Source(s) of the Release & & & $\checkmark$ & $\checkmark$ & $\checkmark$ & $\checkmark$ & $\checkmark$ & $\checkmark$ & $\checkmark$ \\
\hline Comply with Applicable Federal, State, and Local Standards for Waste Management & $\checkmark$ & $\checkmark$ & $\checkmark$ & $\checkmark$ & $\checkmark$ & $\checkmark$ & $\checkmark$ & $\checkmark$ & $\checkmark$ \\
\hline Short-Term Reliability and Effectiveness & & $\checkmark$ & $\checkmark$ & $\checkmark$ & $\checkmark$ & $\checkmark$ & $\checkmark$ & $\checkmark$ & $\checkmark$ \\
\hline Reduction of Toxicity, Mobility, and/or Volume & $\checkmark$ & $\checkmark$ & $\checkmark$ & $\checkmark$ & $\checkmark$ & $\checkmark$ & $\checkmark$ & $\checkmark$ & $\checkmark$ \\
\hline Long-Term Reliability and Effectiveness & & $\checkmark$ & $\checkmark$ & $\checkmark$ & $\checkmark$ & $\checkmark$ & $\checkmark$ & $\checkmark$ & $\checkmark$ \\
\hline Feasibility & & $\checkmark$ & $\checkmark$ & $\checkmark$ & $\checkmark$ & $\checkmark$ & $\checkmark$ & $\checkmark$ & $\checkmark$ \\
\hline Cost (For cost comparison see Appendix C.) & & & & & & & & & \\
\hline
\end{tabular}




\section{Table 3-3}

\section{Comparative Evaluation of Corrective Action Alternatives for Sites Exceeding Action Levels}

\section{(Page 7 of 8 )}

$\checkmark$ indicates that the listed alternative meets the evaluation criteria, $2 \mathrm{~A}=$ site postings, $2 \mathrm{~B}=$ partial excavation with engineered backfill, $2 \mathrm{C}=$ engineered cover,

$3 \mathrm{~A}=$ Disposal at the NTS, 3B = Disposal at a private facility, $3 \mathrm{C}=$ Disposal at the central mud pit, 4A = landfarming, 4B = in situ

\begin{tabular}{|c|c|c|c|c|c|c|c|c|c|}
\hline \multirow{2}{*}{$\begin{array}{l}\text { UC-4 Contamination Site } \\
\text { CAS 58-10-02 Shaker Pad Area (U4S) } \\
\text { Evaluation Criteria }\end{array}$} & \multirow[t]{2}{*}{$\begin{array}{l}\text { Alternative } 1 \\
\text { No Action }\end{array}$} & \multicolumn{3}{|c|}{$\begin{array}{c}\text { Alternative } 2 \\
\text { Administrative } \\
\text { Controls } \\
\end{array}$} & \multicolumn{3}{|c|}{$\begin{array}{l}\text { Alternative } 3 \\
\text { Clean Closure }\end{array}$} & \multicolumn{2}{|c|}{$\begin{array}{c}\text { Alternative } 4 \\
\text { Bioremediation }\end{array}$} \\
\hline & & $\overline{2 A}$ & $2 \mathrm{~B}$ & $2 \mathrm{C}$ & $3 \mathrm{~A}$ & $3 \mathrm{~B}$ & $3 \mathrm{C}$ & $4 \mathrm{~A}$ & $4 \mathrm{~B}$ \\
\hline Protection of Human Health and the Environment & & $\checkmark$ & $\checkmark$ & $\checkmark$ & $\checkmark$ & $\checkmark$ & $\checkmark$ & $\checkmark$ & $\checkmark$ \\
\hline Compliance with Media Cleanup Standards & & $\checkmark$ & $\checkmark$ & $\checkmark$ & $\checkmark$ & $\checkmark$ & $\checkmark$ & $\checkmark$ & $\checkmark$ \\
\hline Control the Source(s) of the Release & & & $\checkmark$ & $\checkmark$ & $\checkmark$ & $\checkmark$ & $\checkmark$ & $\checkmark$ & $\checkmark$ \\
\hline Comply with Applicable Federal, State, and Local Standards for Waste Management & $\checkmark$ & $\checkmark$ & $\checkmark$ & $\checkmark$ & $\checkmark$ & $\checkmark$ & $\checkmark$ & $\checkmark$ & $\checkmark$ \\
\hline Short-Term Reliability and Effectiveness & & $\checkmark$ & $\checkmark$ & $\checkmark$ & $\checkmark$ & $\checkmark$ & $\checkmark$ & $\checkmark$ & $\checkmark$ \\
\hline Reduction of Toxicity, Mobility, and/or Volume & $\checkmark$ & $\checkmark$ & $\checkmark$ & $\checkmark$ & $\checkmark$ & $\checkmark$ & $\checkmark$ & $\checkmark$ & $\checkmark$ \\
\hline Long-Term Reliability and Effectiveness & & $\checkmark$ & $\checkmark$ & $\checkmark$ & $\checkmark$ & $\checkmark$ & $\checkmark$ & $\checkmark$ & $\checkmark$ \\
\hline Feasibility & & & $\checkmark$ & & $\checkmark$ & $\checkmark$ & $\checkmark$ & & \\
\hline \multicolumn{10}{|l|}{ Cost (For cost comparison see Appendix C.) } \\
\hline \multirow{2}{*}{$\begin{array}{l}\text { UC-4 Contamination Site } \\
\text { CAS 58-10-04 Shaker Pad Area (U4W) } \\
\text { Evaluation Criteria }\end{array}$} & \multirow[t]{2}{*}{$\begin{array}{c}\text { Alternative } 1 \\
\text { No Action }\end{array}$} & \multicolumn{3}{|c|}{$\begin{array}{l}\text { Alternative } 2 \\
\text { Administrative } \\
\text { Controls }\end{array}$} & \multicolumn{3}{|c|}{$\begin{array}{l}\text { Alternative } 3 \\
\text { Clean Closure }\end{array}$} & \multicolumn{2}{|c|}{$\begin{array}{c}\text { Alternative } 4 \\
\text { Bioremediation }\end{array}$} \\
\hline & & $2 \mathrm{~A}$ & $2 \mathrm{~B}$ & $2 \mathrm{C}$ & $\overline{3 A}$ & $3 \mathbf{B}$ & $3 \mathrm{C}$ & $4 \mathrm{~A}$ & $4 \mathrm{~B}$ \\
\hline Protection of Human Health and the Environment & & $\checkmark$ & $\checkmark$ & $\checkmark$ & $\checkmark$ & $\checkmark$ & $\checkmark$ & $\checkmark$ & $\checkmark$ \\
\hline Compliance with Media Cleanup Standards & & $\checkmark$ & $\checkmark$ & $\checkmark$ & $\checkmark$ & $\checkmark$ & $\checkmark$ & $\checkmark$ & $\checkmark$ \\
\hline Control the Source(s) of the Release & & & $\checkmark$ & $\checkmark$ & $\checkmark$ & $\checkmark$ & $\checkmark$ & $\checkmark$ & $\checkmark$ \\
\hline Comply with Applicable Federal, State, and Local Standards for Waste Management & $\checkmark$ & $\checkmark$ & $\checkmark$ & $\checkmark$ & $\checkmark$ & $\checkmark$ & $\checkmark$ & $\checkmark$ & $\checkmark$ \\
\hline Short-Term Reliability and Effectiveness & & $\checkmark$ & $\checkmark$ & $\checkmark$ & $\checkmark$ & $\checkmark$ & $\checkmark$ & $\checkmark$ & $\checkmark$ \\
\hline Reduction of Toxicity, Mobility, and/or Volume & $\checkmark$ & $\checkmark$ & $\checkmark$ & $\checkmark$ & $\checkmark$ & $\checkmark$ & $\checkmark$ & $\checkmark$ & $\checkmark$ \\
\hline Long-Term Reliability and Effectiveness & & $\checkmark$ & $\checkmark$ & $\checkmark$ & $\checkmark$ & $\checkmark$ & $\checkmark$ & $\checkmark$ & $\checkmark$ \\
\hline Feasibility & & & $\checkmark$ & & $\checkmark$ & $\checkmark$ & $\checkmark$ & & \\
\hline Cost (For cost comparison see Appendix C.) & & & & & & & & & \\
\hline
\end{tabular}




\section{Comparative Evaluation of Corrective Action Alternatives for Sites Exceeding Action Levels}

\section{Table 3-3}

\section{(Page 8 of 8 )}

$\checkmark$ indicates that the listed alternative meets the evaluation criteria, $2 \mathrm{~A}=$ site postings, $2 \mathrm{~B}=$ partial excavation with engineered backfill, $2 \mathrm{C}=$ engineered cover,

3A $=$ Disposal at the NTS, 3B $=$ Disposal at a private facility, $3 \mathrm{C}=$ Disposal at the central mud pit, 4A $=$ landfarming, 4B $=$ in situ

\begin{tabular}{|c|c|c|c|c|c|c|c|c|c|}
\hline \multirow{2}{*}{$\begin{array}{l}\text { UC-4 Contamination Site } \\
\text { CAS 58-10-05 Shaker Pad Area (U4X) } \\
\text { Evaluation Criteria }\end{array}$} & \multirow[t]{2}{*}{$\begin{array}{c}\text { Alternative } 1 \\
\text { No Action }\end{array}$} & \multicolumn{3}{|c|}{$\begin{array}{c}\text { Alternative } 2 \\
\text { Administrative } \\
\text { Controls }\end{array}$} & \multicolumn{3}{|c|}{$\begin{array}{l}\text { Alternative } 3 \\
\text { Clean Closure }\end{array}$} & \multicolumn{2}{|c|}{$\begin{array}{c}\text { Alternative } 4 \\
\text { Bioremediation }\end{array}$} \\
\hline & & $\overline{2 A}$ & $2 \mathrm{~B}$ & $\overline{2 \mathrm{C}}$ & $\overline{3 \mathrm{~A}}$ & $3 \mathrm{~B}$ & $3 \mathrm{C}$ & $4 \mathrm{~A}$ & $4 \mathrm{~B}$ \\
\hline Protection of Human Health and the Environment & & $\checkmark$ & $\checkmark$ & $\checkmark$ & $\checkmark$ & $\checkmark$ & $\checkmark$ & $\checkmark$ & $\checkmark$ \\
\hline Compliance with Media Cleanup Standards & & $\checkmark$ & $\checkmark$ & $\checkmark$ & $\checkmark$ & $\checkmark$ & $\checkmark$ & $\checkmark$ & $\checkmark$ \\
\hline Control the Source(s) of the Release & & & $\checkmark$ & $\checkmark$ & $\checkmark$ & $\checkmark$ & $\checkmark$ & $\checkmark$ & $\checkmark$ \\
\hline Comply with Applicable Federal, State, and Local Standards for Waste Management & $\checkmark$ & $\checkmark$ & $\checkmark$ & $\checkmark$ & $\checkmark$ & $\checkmark$ & $\checkmark$ & $\checkmark$ & $\checkmark$ \\
\hline Short-Term Reliability and Effectiveness & & $\checkmark$ & $\checkmark$ & $\checkmark$ & $\checkmark$ & $\checkmark$ & $\checkmark$ & $\checkmark$ & $\checkmark$ \\
\hline Reduction of Toxicity, Mobility, and/or Volume & $\checkmark$ & $\checkmark$ & $\checkmark$ & $\checkmark$ & $\checkmark$ & $\checkmark$ & $\checkmark$ & $\checkmark$ & $\checkmark$ \\
\hline Long-Term Reliability and Effectiveness & & $\checkmark$ & $\checkmark$ & $\checkmark$ & $\checkmark$ & $\checkmark$ & $\checkmark$ & $\checkmark$ & $\checkmark$ \\
\hline Feasibility & & $\checkmark$ & $\checkmark$ & $\checkmark$ & $\checkmark$ & $\checkmark$ & $\checkmark$ & $\checkmark$ & $\checkmark$ \\
\hline Cost (For cost comparison see Appendix C.) & & & & & & & & & \\
\hline
\end{tabular}




\subsection{Recommended Alternative}

The preferred corrective action alternative for each CAS is presented in Table 4-1. The results are based on the Table 3-3 comparative analysis of the potential corrective action alternatives presented in this document and in Appendix C.

\subsection{Alternative 1 - No Action}

No Action was chosen as the corrective action measure for the following CASs:

UC-1 Septic System 58-05-01

UC-1 Decon Facility Pit 58-07-01

UC-1 Mud Pit 58-09-04 (HTH-1 Well)

UC-1 Grout Pile 58-44-05

UC-1 Equipment \& Staging Areas U1C 58-09-05

06

UC-1 Equipment \& Staging Areas U1D 58-09-05

UC-1 Area X West of CMP Drilling mud/grout piles 58-44-01

UC-1 Area X Southeast of UC-1 Drilling mud/grout piles 58-44-02

UC-1 Burn Pit 58-35-01

UC-1 Waste Pile 58-98-03

UC-4 Scrap \& Trash Dump east of UC-4 SGZ

UC-4 Septic System 58-05-04

UC-4 Mud Pit U4E 58-09-03
UC-3 Drill Mud/Grout Spill Area U3Y 58-44-04

UC-3 Recording Trailer Park UST 58-05-03

UC-3 UST (U3U) 58-99-01

UC-3 Septic System 58-05-05

UC-3 Recording Trailer Park Septic Tank 58-05-

UC-3 Mud pit U3A, U3B, U3C, U3D 58-09-06

UC-3 Drill Mud/Cuttings U3X 58-10-06

UC-3 Burn Area 58-35-02

UC-3 Waste Pile 58-98-01

UC-3 Waste Pile 58-98-02

UC-3 Waste Pile 58-98-04

UC-3 Scrap \& Trash Dump 58-19-01

UC-3 Septic System 58-05-02

Alternative 1 was selected for the following reasons:

- No COCs were detected above the $100 \mathrm{mg} / \mathrm{kg}$ TPH action levels in any of the above mentioned CASs.

- Groundwater impact from these CASs is extremely unlikely. Groundwater depth ranges from approximately 61 to $163 \mathrm{~m}$ (200 to $535 \mathrm{ft}$ ) below surface.

- The waste pile, housekeeping debris, UST, and septic tank sites were cleaned up or removed under accelerated programs, as described in Section 2.0 of the CADD.

For those CASs where accelerated actions were implemented and Alternative 1 - No Action is proposed, closure documentation for the CASs will be provided in the Closure Report. 
Table 4-1

Proposed Remedial Alternatives

(Page 1 of 5)

\begin{tabular}{|c|c|c|c|c|c|c|c|c|}
\hline \multirow{2}{*}{$\begin{array}{l}\text { CORRECTIVE } \\
\text { ACTION SITE }\end{array}$} & \multirow{2}{*}{$\begin{array}{l}\text { ALTERNATIVE } 1 \\
\text { NO ACTION }\end{array}$} & \multicolumn{2}{|c|}{$\begin{array}{c}\text { ALTERNATIVE } 2 \\
\text { ADMINISTRATIVE CONTROLS }\end{array}$} & \multicolumn{3}{|c|}{$\begin{array}{l}\text { ALTERNATIVE } 3 \\
\text { CLEAN CLOSURE }\end{array}$} & \multicolumn{2}{|c|}{$\begin{array}{l}\text { ALTERNATIVE } 4 \\
\text { BIOREMEDIATION }\end{array}$} \\
\hline & & Site Posting & $\begin{array}{c}\text { Engineered } \\
\text { Cover }\end{array}$ & $\begin{array}{l}\text { Disposal at } \\
\text { NTS }\end{array}$ & $\begin{array}{c}\text { Disposal at UC- } \\
1 \mathrm{CMP}^{*} \\
\end{array}$ & $\begin{array}{c}\text { Disposal at } \\
\text { Private Facility }\end{array}$ & In situ & $\begin{array}{l}\text { On-Site } \\
\text { Landfarm }\end{array}$ \\
\hline \multicolumn{9}{|l|}{ UC-1 Area } \\
\hline $\begin{array}{l}\text { 58-05-01 } \\
\text { Septic System }\end{array}$ & $x$ & & & & & & & \\
\hline $\begin{array}{l}\text { 58-07-01 } \\
\text { Decon Facility Pit } \\
\text { (SAME AS 58-35-01) }\end{array}$ & $x$ & & & & & & & \\
\hline $\begin{array}{l}58-09-01 \\
\text { Central Mud Pit }\end{array}$ & & & $x$ & & & & & \\
\hline $\begin{array}{l}\text { 58-09-02 } \\
\text { Mud Pit U1A }\end{array}$ & & $x$ & & & & & & \\
\hline $\begin{array}{l}\text { 58-09-04 } \\
\text { Drill Pad } \\
\text { (New name) } \\
\text { old=mud pit U1B }\end{array}$ & $x$ & & & & & & & \\
\hline $\begin{array}{l}\text { 58-09-05 } \\
\text { Mud Pit U1C/ Equipment } \\
\text { \& Staging Areas }\end{array}$ & $x$ & & & & & & & \\
\hline $\begin{array}{l}\text { 58-09-05 } \\
\text { Mud Pit U1D/ Equipment } \\
\text { \& Staging Areas }\end{array}$ & $x$ & & & & & & & \\
\hline $\begin{array}{l}\text { 58-09-05 } \\
\text { Mud Pit U1E }\end{array}$ & & $x$ & & & & & & \\
\hline $\begin{array}{l}\text { 58-10-03 } \\
\text { Shaker Pad Area (U1S) }\end{array}$ & & & & & $x$ & & & \\
\hline $\begin{array}{l}\text { 58-35-01 } \\
\text { Burn Area } \\
\text { (SAME AS 58-07-01) }\end{array}$ & $x$ & & & & & & & \\
\hline
\end{tabular}


Table 4-1

Proposed Remedial Alternatives

(Page 2 of 5)

\begin{tabular}{|c|c|c|c|c|c|c|c|c|}
\hline \multirow{2}{*}{$\begin{array}{l}\text { CORRECTIVE } \\
\text { ACTION SITE }\end{array}$} & \multirow{2}{*}{$\begin{array}{l}\text { ALTERNATIVE } 1 \\
\text { NO ACTION }\end{array}$} & \multicolumn{2}{|c|}{$\begin{array}{c}\text { ALTERNATIVE } 2 \\
\text { ADMINISTRATIVE CONTROLS }\end{array}$} & \multicolumn{3}{|c|}{$\begin{array}{l}\text { ALTERNATIVE } 3 \\
\text { CLEAN CLOSURE }\end{array}$} & \multicolumn{2}{|c|}{$\begin{array}{l}\text { ALTERNATIVE } 4 \\
\text { BIOREMEDIATION }\end{array}$} \\
\hline & & Site Posting & $\begin{array}{c}\text { Engineered } \\
\text { Cover }\end{array}$ & $\begin{array}{l}\text { Disposal at } \\
\text { NTS }\end{array}$ & $\begin{array}{c}\text { Disposal at UC- } \\
1 \mathrm{CMP}^{\star}\end{array}$ & $\begin{array}{c}\text { Disposal at } \\
\text { Private Facility }\end{array}$ & In situ & $\begin{array}{l}\text { On-Site } \\
\text { Landfarm }\end{array}$ \\
\hline $\begin{array}{l}\text { 58-44-01 } \\
\text { Drilling mud/grout piles } \\
\text { UC-1 Area X West of } \\
\text { CMP }\end{array}$ & $x$ & & & & & & & \\
\hline $\begin{array}{l}58-44-02 \\
\text { Drilling mud/grout piles } \\
\text { UC-1 Area X Southeast } \\
\text { of UC-1 }\end{array}$ & $x$ & & & & & & & \\
\hline $\begin{array}{l}\text { 58-44-05 } \\
\text { Grout Pile Northeast of } \\
\text { UC-1 }\end{array}$ & $x$ & & & & & & & \\
\hline $\begin{array}{l}\text { 58-44-06 } \\
\text { Borrow Pit } \\
\text { (New name) } \\
\text { old=grout pile U1Y }\end{array}$ & & $x$ & & & & & & \\
\hline \multicolumn{9}{|l|}{ UC-3 Area } \\
\hline $\begin{array}{l}58-05-02 \\
\text { Septic System }\end{array}$ & $x$ & & & & & & & \\
\hline $\begin{array}{l}\text { 58-05-03 } \\
\text { Recording Trailer Park } \\
\text { UST }\end{array}$ & $x$ & & & & & & & \\
\hline $\begin{array}{l}\text { 58-05-05 } \\
\text { Septic System }\end{array}$ & $x$ & & & & & & & \\
\hline $\begin{array}{l}\text { 58-05-06 } \\
\text { Recording Trailer Park } \\
\text { Septic Tank } \\
\text { old=septic system }\end{array}$ & $x$ & & & & & & & \\
\hline $\begin{array}{l}\text { 58-09-06 } \\
\text { Mud Pit U3A }\end{array}$ & $x$ & & & & & & & \\
\hline
\end{tabular}


Table 4-1

Proposed Remedial Alternatives

(Page 3 of 5)

\begin{tabular}{|c|c|c|c|c|c|c|c|c|}
\hline \multirow{2}{*}{$\begin{array}{l}\text { CORRECTIVE } \\
\text { ACTION SITE }\end{array}$} & \multirow{2}{*}{$\begin{array}{l}\text { ALTERNATIVE } 1 \\
\text { NO ACTION }\end{array}$} & \multicolumn{2}{|c|}{$\begin{array}{c}\text { ALTERNATIVE } 2 \\
\text { ADMINISTRATIVE CONTROLS }\end{array}$} & \multicolumn{3}{|c|}{$\begin{array}{l}\text { ALTERNATIVE } 3 \\
\text { CLEAN CLOSURE }\end{array}$} & \multicolumn{2}{|c|}{$\begin{array}{l}\text { ALTERNATIVE } 4 \\
\text { BIOREMEDIATION }\end{array}$} \\
\hline & & Site Posting & $\begin{array}{c}\text { Engineered } \\
\text { Cover }\end{array}$ & $\begin{array}{c}\text { Disposal at } \\
\text { NTS }\end{array}$ & $\begin{array}{c}\text { Disposal at UC- } \\
1 \mathrm{CMP}^{\star} \\
\end{array}$ & $\begin{array}{c}\text { Disposal at } \\
\text { Private Facility } \\
\end{array}$ & In situ & $\begin{array}{c}\text { On-Site } \\
\text { Landfarm }\end{array}$ \\
\hline $\begin{array}{l}\text { 58-09-06 } \\
\text { Mud Pit U3B }\end{array}$ & $x$ & & & & & & & \\
\hline $\begin{array}{l}\text { 58-09-06 } \\
\text { Mud Pit U3C }\end{array}$ & $x$ & & & & & & & \\
\hline $\begin{array}{l}\text { 58-09-06 } \\
\text { Mud Pit U3D }\end{array}$ & $x$ & & & & & & & \\
\hline $\begin{array}{l}\text { 58-09-06 } \\
\text { Mud Pit U3E }\end{array}$ & & $x$ & & & & & & \\
\hline $\begin{array}{l}\text { 58-10-01 } \\
\text { Shaker Pad Area (U3S) }\end{array}$ & & $x$ & & & & & & \\
\hline $\begin{array}{l}\text { 58-10-06 } \\
\text { Drill Mud/Cuttings } \\
\text { (U3X) }\end{array}$ & $x$ & & & & & & & \\
\hline $\begin{array}{l}\text { 58-19-01 } \\
\text { Scrap \& Trash Dump }\end{array}$ & $x$ & & & & & & & \\
\hline $\begin{array}{l}\text { 58-25-01 } \\
\text { Spill Southern Outlier } \\
\text { (U3E) }\end{array}$ & & $x$ & & & & & & \\
\hline $\begin{array}{l}58-35-02 \\
\text { Burn Area }\end{array}$ & $x$ & & & & & & & \\
\hline $\begin{array}{l}58-44-03 \\
\text { Drill Mud/Grout Spill } \\
\text { Area (U3Z) }\end{array}$ & & & & & $x$ & & & \\
\hline $\begin{array}{l}\text { 58-44-04 } \\
\text { Drill Mud/Grout Spill } \\
\text { Area } \\
\text { (U3Y) }\end{array}$ & $x$ & & & & & & & \\
\hline
\end{tabular}


Table 4-1

Proposed Remedial Alternatives

(Page 4 of 5)

\begin{tabular}{|c|c|c|c|c|c|c|c|c|}
\hline \multirow{2}{*}{$\begin{array}{l}\text { CORRECTIVE } \\
\text { ACTION SITE }\end{array}$} & \multirow{2}{*}{$\begin{array}{l}\text { ALTERNATIVE } 1 \\
\text { NO ACTION }\end{array}$} & \multicolumn{2}{|c|}{$\begin{array}{c}\text { ALTERNATIVE } 2 \\
\text { ADMINISTRATIVE CONTROLS }\end{array}$} & \multicolumn{3}{|c|}{$\begin{array}{l}\text { ALTERNATIVE } 3 \\
\text { CLEAN CLOSURE }\end{array}$} & \multicolumn{2}{|c|}{$\begin{array}{l}\text { ALTERNATIVE } 4 \\
\text { BIOREMEDIATION }\end{array}$} \\
\hline & & Site Posting & $\begin{array}{c}\text { Engineered } \\
\text { Cover }\end{array}$ & $\begin{array}{c}\text { Disposal at } \\
\text { NTS }\end{array}$ & $\begin{array}{c}\text { Disposal at UC- } \\
1 \mathrm{CMP}^{\star} \\
\end{array}$ & $\begin{array}{c}\text { Disposal at } \\
\text { Private Facility } \\
\end{array}$ & In situ & $\begin{array}{c}\text { On-Site } \\
\text { Landfarm }\end{array}$ \\
\hline $\begin{array}{l}58-98-01 \\
\text { Waste Pile }\end{array}$ & $x$ & & & & & & & \\
\hline $\begin{array}{l}58-98-02 \\
\text { Waste Pile }\end{array}$ & $x$ & & & & & & & \\
\hline $\begin{array}{l}58-98-03 \\
\text { Waste Pile }\end{array}$ & $x$ & & & & & & & \\
\hline $\begin{array}{l}58-98-04 \\
\text { Waste Pile }\end{array}$ & $x$ & & & & & & & \\
\hline $\begin{array}{l}58-99-01 \\
\text { UC3 UST } \\
\text { old=protruding pipes }\end{array}$ & $x$ & & & & & & & \\
\hline
\end{tabular}


Table 4-1

Proposed Remedial Alternatives

(Page 5 of 5)

\begin{tabular}{|c|c|c|c|c|c|c|c|c|}
\hline \multirow{2}{*}{$\begin{array}{l}\text { CORRECTIVE } \\
\text { ACTION SITE }\end{array}$} & \multirow{2}{*}{$\begin{array}{l}\text { ALTERNATIVE } 1 \\
\text { NO ACTION }\end{array}$} & \multicolumn{2}{|c|}{$\begin{array}{c}\text { ALTERNATIVE } 2 \\
\text { ADMINISTRATIVE CONTROLS }\end{array}$} & \multicolumn{3}{|c|}{$\begin{array}{l}\text { ALTERNATIVE } 3 \\
\text { CLEAN CLOSURE }\end{array}$} & \multicolumn{2}{|c|}{$\begin{array}{l}\text { ALTERNATIVE } 4 \\
\text { BIOREMEDIATION }\end{array}$} \\
\hline & & Site Posting & $\begin{array}{c}\text { Engineered } \\
\text { Cover }\end{array}$ & $\begin{array}{c}\text { Disposal at } \\
\text { NTS }\end{array}$ & $\begin{array}{c}\text { Disposal at UC- } \\
1 \mathrm{CMP}^{\star} \\
\end{array}$ & $\begin{array}{c}\text { Disposal at } \\
\text { Private Facility } \\
\end{array}$ & In situ & $\begin{array}{c}\text { On-Site } \\
\text { Landfarm }\end{array}$ \\
\hline \multicolumn{9}{|l|}{ UC-4 Area } \\
\hline $\begin{array}{l}\text { 58-05-04 } \\
\text { Septic System }\end{array}$ & $x$ & & & & & & & \\
\hline $\begin{array}{l}\text { 58-09-03 } \\
\text { Mud Pits U4A }\end{array}$ & & $x$ & & & & & & \\
\hline $\begin{array}{l}\text { 58-09-03 } \\
\text { Mud Pits U4B }\end{array}$ & & $x$ & & & & & & \\
\hline $\begin{array}{l}\text { 58-09-03 } \\
\text { Mud Pits U4C }\end{array}$ & & & $x$ & & & & & \\
\hline $\begin{array}{l}\text { 58-09-03 } \\
\text { Mud Pits U4D }\end{array}$ & & $x$ & & & & & & \\
\hline $\begin{array}{l}58-10-02 \\
\text { Shaker Pad Area } \\
\text { (U4S) }\end{array}$ & & & & & $x$ & & & \\
\hline $\begin{array}{l}58-10-04 \\
\text { Shaker Pad Area } \\
(\mathrm{U} 4 \mathrm{~W})\end{array}$ & & & & & $x$ & & & \\
\hline $\begin{array}{l}58-10-05 \\
\text { Shaker Pad Area } \\
(\mathrm{U} 4 \mathrm{X})\end{array}$ & & $x$ & & & & & & \\
\hline $\begin{array}{l}\text { 58-09-03 } \\
\text { Mud Pit U4E }\end{array}$ & $x$ & & & & & & & \\
\hline $\begin{array}{l}\text { Not Assigned } \\
\text { Scrap \& Trash Dump } \\
\text { (east of UC-4 SGZ) }\end{array}$ & $x$ & & & & & & & \\
\hline
\end{tabular}

${ }^{\star}$ CMP - Central Mud Pit at UC-1. 


\subsection{Alternative 2 - Administrative Controls}

Use restrictions will be placed on the land to prohibit intrusive activities and farming. Signs can be used to further restrict access. Administrative controls are commonly used and can effectively eliminate potential pathways.

\subsubsection{Site Posting}

Administrative Controls with site posting was chosen as the corrective action measure for CAS numbers:

UC-1 Mud Pit U1A 58-09-02

UC-4 Mud Pit U4A 58-09-03

UC-1 Mud Pit U1E 58-09-05

UC-4 Mud Pit U4B 58-09-03

UC-1 Borrow Pit (U1Y) 58-44-06

UC-4 Mud Pit U4D 58-09-03

UC-3 Mud Pit U3E 58-09-06

UC-4 Shaker Pad Area (U4X) 58-10-05

UC-3 Shaker Pad Area (U3S) 58-10-01

UC-3 Spill Southern Outlier (U3E) 58-25-01

Alternative 2 (site posting) was chosen for the following reasons:

- No COCs, other than TPH, were detected.

- Petroleum Hydrocarbon levels exceed the $100 \mathrm{mg} / \mathrm{kg}$ TPH action level. The above mentioned CASs require administrative controls and site posting to prevent inadvertent intrusions into impacted media.

- The impacted media ranges from surface to a depth of $3 \mathrm{~m}(10 \mathrm{ft})$ and does not pose a significant threat to the environment. The TPH that is present at the CNTA CASs, that are proposed to be closed administratively, has not migrated any significant distance from the original sources in the 30 years it has been in place. TPH has only infiltrated to $22 \mathrm{ft}$ below ground surface in the native soils at the UC-3 Spill Southern Outlier Area (CAS 58-25-01), the CAS with the deepest contamination. At sites such as the UC-3 Mud Pit E (CAS 58-0906), TPH contamination is primarily contained within the drilling mud and has infiltrated to a maximum depth of $0.61 \mathrm{~m}(2 \mathrm{ft})$ in the underlying native soils.

Depth to groundwater ranges from 101 to $168 \mathrm{~m}$ (332 to $551 \mathrm{ft}$ ), and any TPH infiltration would be limited due to low precipitation. It is likely that natural attenuation will occur to TPH contamination within the native soils. Due to unfavorable conditions for microbial activity, natural attenuation will occur at a much slower rate within mud pit material with a high clay content. 
- CASs 58-09-02, 58-09-05, 58-44-06, and 58-09-03 contain impacted surface media, but the maximum concentrations do not exceed 1,000 mg/kg TPH. CASs 58-09-06, UC-3 Mud Pit U3E, and 58-25-01, UC-3 Spill Southern Outlier U3E contain impacted surface media with TPH concentrations from $13.3 \mathrm{mg} / \mathrm{kg}$ to $1074 \mathrm{mg} / \mathrm{kg}$. Maximum subsurface TPH concentrations are 15,400 mg/kg and 17,010 mg/kg for the UC-3 Mud Pit U3E and the UC-3 Spill Southern Outlier U3E, respectively. Based upon the current status of well developed vegetation and existing soil covers for each of the above mentioned surface and subsurface impacted CASs, no CAS is recommended for corrective action beyond implementation of administrative controls and site posting.

- Groundwater impact from these CASs is extremely unlikely. Groundwater depth ranges from approximately 61 to $163 \mathrm{~m}$ (200 to $535 \mathrm{ft})$ below surface.

\subsubsection{Partial Excavation and Engineered Backfill}

Administrative Controls with partial excavation and engineered backfill was not chosen for the following reasons:

- Clean closure with disposal at UC-1 CMP is a more effective closure alternative for a similar cost.

- This alternative requires post closure monitoring and inspections adding to the cost of implementation. Other comparable closure alternatives do not require post closure activities.

\subsubsection{Engineered Cover}

Administrative Controls with construction of an engineered cover was chosen as the corrective action measure for UC-1 CMP (CAS 58-09-01), and UC-4 Mud Pit U4C (CAS 58-09-03).

Alternative 2 (engineered cover) was chosen for the following reasons:

- No COCs, other than TPH, were detected.

- Petroleum hydrocarbon levels exceed the $100 \mathrm{mg} / \mathrm{kg}$ action level and require administrative controls, site posting, and an engineered cover to prevent inadvertent intrusions into impacted media.

- The impacted media ranges from surface to a depth of 1.8-m $(0-6 \mathrm{ft})$ and poses a potential threat to the environment. The absence, or low quantity of vegetation, increases the site susceptibility to run-off and TPH mobility. The absence of vegetation is attributed to the drilling mud and cuttings media, as well as to the absence of soil/nutrients capable of sustaining plant growth. 
- CAS 58-09-01 UC-1 CMP contains 40,182 $\mathrm{m}^{3}\left(52,556 \mathrm{yd}^{3}\right)$ of material with TPH concentrations up to $2,560 \mathrm{mg} / \mathrm{kg}$. The contamination ranges from surface to a depth of $1.8 \mathrm{~m}(6 \mathrm{ft})$. The large volume of impacted soil and low load bearing capacity of the site require construction of an engineered cover and site posting to prevent inadvertent intrusion into the CAS.

- CAS 58-09-03 UC-4 Mud Pit U4C contains 1,359 $\mathrm{m}^{3}$ (1,778 $\left.\mathrm{yd}^{3}\right)$ of material with TPH concentrations up to $985 \mathrm{mg} / \mathrm{kg}$. The contamination ranges from the surface to a depth of $0.61 \mathrm{~m}(2 \mathrm{ft})$. Based upon the poor vegetative status and low load bearing capacity of the site, construction of an engineered cover prior to site posting and administrative control is recommended.

- Groundwater impact from these CASs is extremely unlikely. Groundwater depth is

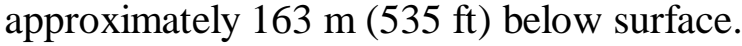

\subsection{Alternative 3 - Clean Closure with Disposal at UC-1 Central Mud Pit}

Clean Closure with Disposal at UC-1 CMP was chosen as the corrective action measure for CAS numbers:

UC-1 Shaker Pad Area (U1S) 58-10-03

UC-3 Drill Mud/Grout Spill Area (U3Z) 58-44-03

UC-4 Shaker Pad Area (U4S) 58-10-02

UC-4 Shaker Pad Area (U4W) 58-10-04

Alternative 3, Clean Closure with Disposal at UC-1 CMP was chosen for the following reasons:

- The increase in volume to CMP material due to excavated materials will be approximately $9,035 \mathrm{~m}^{3}\left(11,840 \mathrm{yd}^{3}\right)$, which will not adversely effect the implementation of the CMP closure alternative - Engineered Cover.

- No post closure monitoring requirements for this alternative.

- The cost of implementing this alternative is comparable to other less effective alternatives when all activities are considered.

\subsection{Alternative 4 - Bioremediation}

Bioremediation, in situ and on-site land farming, were not selected as closure alternatives for the following reasons:

- Implementation. Bioremediation is not feasible due to the clay-like consistency of the drilling mud. It would be very difficult to mix in the necessary nutrients, provide aeration, and adjust the $\mathrm{pH}$ to an appropriate range to allow successful microbial activity. 
- Implementation. Land farming was not chosen since this technique would require removing contaminated soils and muds in one foot lifts, applying them to a cleared surface area, and mixing in nutrients to promote microbial activity. This technique is time consuming and expensive to implement.

- Time requirements. Both bioremediation alternatives require more time than other equally effective closure alternatives.

- Monitoring requirements. Monitoring and sampling during the implementation of this alternative may be required. Also, post closure monitoring/sampling may be required; therefore costing more than other equally effective closure alternatives."

- Cost. Both alternatives would be as or more costly than equally effective closure alternatives. 


\subsection{References}

AEC, see U.S. Atomic Energy Commission.

CFR, see Code of Federal Regulations.

Code of Federal Regulations. 1996. Title 40 CFR Parts 261 - 281, "RCRA Regulations."

Washington, DC: U.S. Government Printing Office.

DOA, see U.S. Department of Agriculture.

DOE/NV, see U.S. Department of Energy, Nevada Operations Office.

EPA, see U.S. Environmental Protection Agency.

FFACO, see Federal Facility Agreement and Consent Order.

Federal Facility Agreement and Consent Order. 1996. Agreed to by the State of Nevada, the U.S. Department of Energy, and the U.S. Department of Defense.

NAC, see Nevada Administrative Code.

Nevada Administrative Code. 1996a. NAC 459, "Disposal and Evaluation of Contaminated Soil." Carson City, NV.

Nevada Administrative Code. 1996b. NAC 445A, "Water Pollution Control." Carson City, NV.

Nevada Administrative Code. 1998. NAC 444, "Sewage Disposal." Carson City, NV.

NRS, see Nevada Revised Statutes.

Nevada Revised Statues. 1995. NRS 459.400-459-600, "Disposal of Hazardous Waste." Carson City, NV.

Rush, F.E., and D.E. Everett. 1966. Water-Resources Appraisal of Little Fish Lake, Monitor, Hot Creek, and Little Smoky Valleys Nevada, Water Resources Reconnaissance Series Report 38. Carson City, NV: State of Nevada, Department of Conservation and Natural Resources.

Schaeffer, J.R. 1968. Climatology of the Tonopah Test Range, SC-M-68-522.

Albuquerque, NM: Sandia National Laboratories.

U.S. Atomic Energy Commission, Nevada Operations Office. 1973. Planning Directive:

Demobilization, Restoration and Monitoring, Central Nevada Test Area, NVO-90.

Las Vegas, NV. 
U.S. Department of Agriculture. 1974. "Soil Survey Maps of Northeast Nye County, Nevada." Reno, NV: Natural Resources Conservation Service.

U.S. Department of Energy, Nevada Operations Office. 1994a. Nevada Environmental Restoration Health and Safety Plan. Las Vegas, NV.

U.S. Department of Energy, Nevada Operations Office. 1994b. Project Management Plan, Rev. 0. Las Vegas, NV.

U.S. Department of Energy, Nevada Operations Office. 1996a. Corrective Action Investigation Plan, Second Gas Station, Underground Storage Tanks, Tonopah Test Range, Rev. 1, DOE/NV-426. Las Vegas, NV.

U.S. Department of Energy, Nevada Operations Office. 1996b. Industrial Sites Quality Assurance Project Plan, DOE/NV--372. Las Vegas, NV.

U.S. Department of Energy, Nevada Operations Office. 1997. Corrective Action Investigation Plan for Central Nevada Test Area CAU No. 417, DOE/NV--450, Rev. 1. Las Vegas, NV.

U.S. Department of Energy, Nevada Operations Office. 1998. Addendum to the Corrective Action Investigation Plan for Central Nevada Test Area, CAU No. 417, DOE/NV--450. Las Vegas, NV.

U.S. Environmental Protection Agency. 1991. Guidance on RCRA Corrective Action Decision Documents, EPA/540/G-91/011. Washington, DC: Office of Research and Development.

U.S. Environmental Protection Agency. 1994. Final RCRA Corrective Action Plan, EPA/520-R-94-004. Washington, DC: Office of Solid Waste and Emergency Response.

U.S. Environmental Protection Agency. 1998. Memo from S.J. Smucker regarding Region 9 Preliminary Remediation Goals, 1 August. San Francisco, CA. 
CADD CAU 417 CNTA

Section: Appendix A

Revision: 1

Date: 04/05/99

Page A-1 of A-4

\section{Appendix A}

\section{Cost Estimates}




\begin{tabular}{|c|c|c|c|c|c|c|c|c|c|c|c|c|c|c|}
\hline & REMEDIALALIERNATIVES & 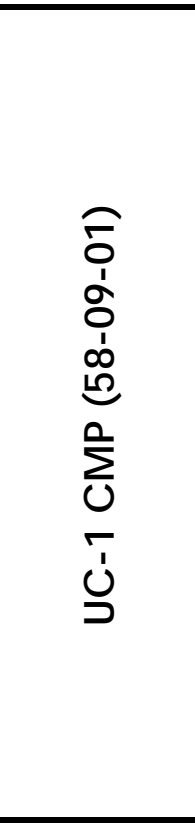 & 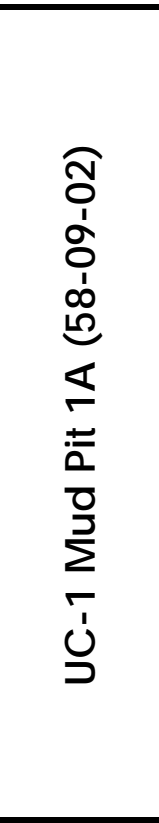 & 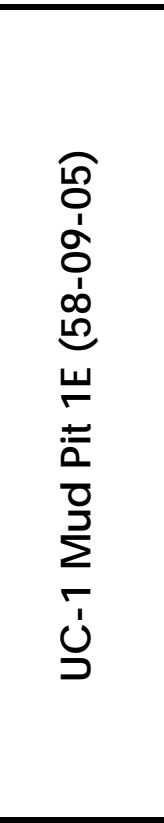 & 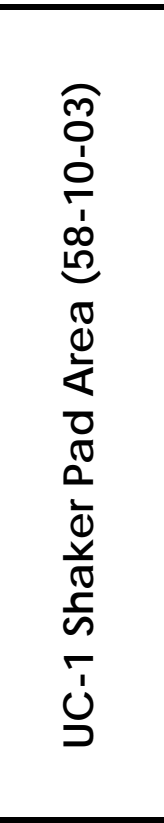 & 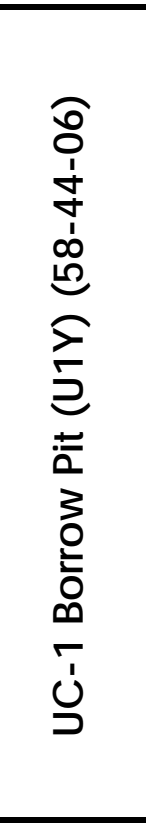 & 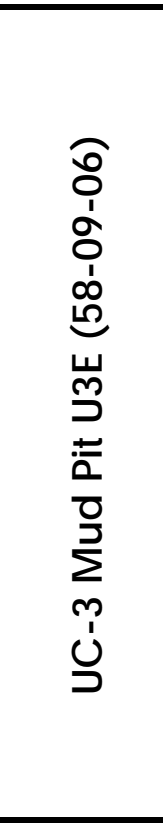 & 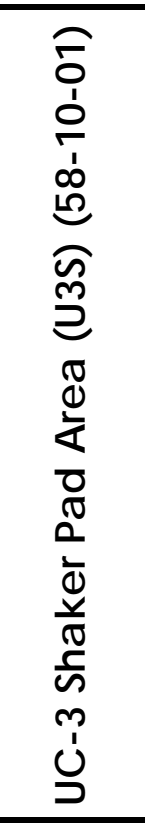 & 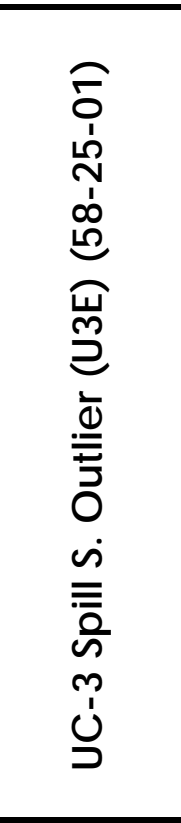 & 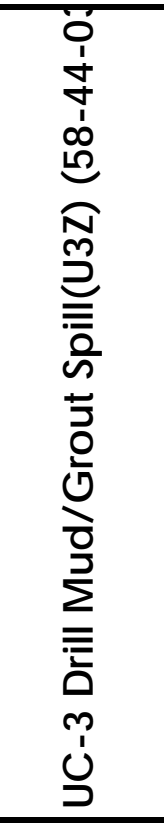 & 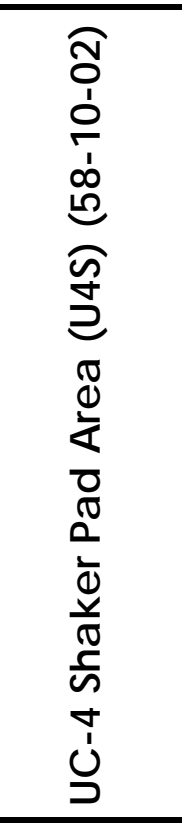 & 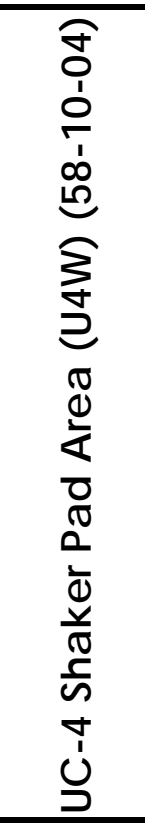 & 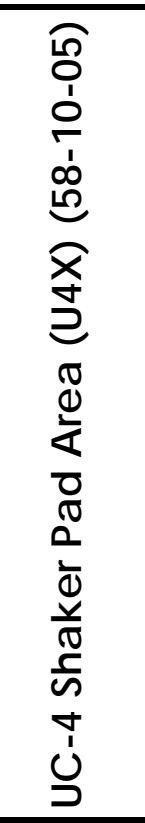 & 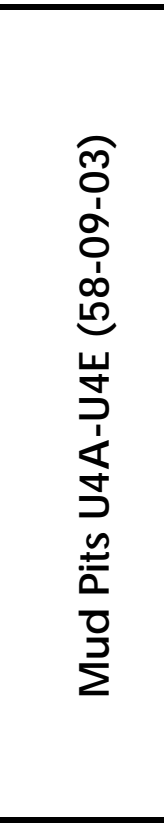 \\
\hline \multirow[t]{2}{*}{1} & ALTERNATIVE I & & & & & & & & & & & & & \\
\hline & -NO AC ION & $\$ 0$ & $\$ 0$ & $\$ 0$ & $\$ 0$ & $\$ 0$ & $\$ 0$ & $\$ 0$ & $\$ 0$ & $\$ 0$ & $\$ 0$ & $\$ 0$ & $\$ 0$ & $\$ 0$ \\
\hline 2 & ALTERNATIVE II & & & & & & & & & & & & & \\
\hline $2 \mathrm{~A}$ & ADMINISTRATIVE CONTROLS-STIE POSIINGS & $\$ 5,415$ & $\$ 2,929$ & $\$ 2,929$ & $\$ 2,929$ & $\$ 2,929$ & $\$ 2,929$ & $\$ 1,064$ & $\$ 2,929$ & $\$ 2,929$ & $\$ 2,929$ & $\$ 2,929$ & $\$ 2,929$ & $\$ 5,415$ \\
\hline $2 \mathrm{~B}$ & ADMINISTRATIVE CONIROLS-PARTIALEXC \& ENG BACKAL & $\$ 178,087$ & $\$ 23,669$ & $\$ 23,669$ & $\$ 84,913$ & $\$ 17,544$ & $\$ 54,291$ & $\$ 35,918$ & $\$ 195,152$ & $\$ 17,544$ & $\$ 72,664$ & $\$ 23,669$ & $\$ 29,793$ & $\$ 72,664$ \\
\hline $2 \mathrm{C}$ & ADMINISTRATIVE CONIROLS-ENGINERING COVER & $\$ 541,485$ & $\$ 103,110$ & $\$ 103,110$ & $\$ 162,436$ & $\$ 43,983$ & $\$ 51,317$ & $\$ 29,990$ & $\$ 78,393$ & $\$ 47,237$ & $\$ 244,847$ & $\$ 57,332$ & $\$ 35,271$ & $\$ 92,941$ \\
\hline 3 & ALTERNATIVE III-CLEAN CLOSE \& DISPOSAL & & & & & & & & & & & & & \\
\hline $3 \mathrm{~A}$ & CLEAN CLOSE-DISPOSALATTHE NTS & $\$ 7,919,151$ & $\$ 115,424$ & $\$ 133,453$ & $\$ 205,701$ & $\$ 11,934$ & $\$ 343,345$ & $\$ 28,054$ & $\$ 1,767,048$ & $\$ 164,309$ & $\$ 1,657,173$ & $\$ 74,443$ & $\$ 21,086$ & $\$ 1,350,998$ \\
\hline $3 B$ & CLEAN CLOSE-DISPOSALATTHE PRIVATE FACIUTY (RENO/LV) & & & & & & & & & & & & & \\
\hline $3 B .1$ & \begin{tabular}{|l} 
High Range cost \\
\end{tabular} & $\$ 18,782,104$ & $\$ 262, \pi 77$ & $\$ 305,799$ & $\$ 494,414$ & $\$ 18,366$ & $\$ 1,163,001$ & $\$ 96,566$ & $\$ 5,936,091$ & $\$ 545,454$ & $\$ 5,625,759$ & $\$ 250,601$ & $\$ 65,212$ & $\$ 4,612,862$ \\
\hline $3 B .2$ & Low Range cost & $\$ 11,320,802$ & $\$ 161,815$ & $\$ 187,655$ & $\$ 299,756$ & $\$ 14,196$ & $\$ 796,371$ & $\$ 66,041$ & $\$ 4,088,091$ & $\$ 376,494$ & $\$ 3,865,704$ & $\$ 172,391$ & $\$ 45,472$ & $\$ 3,165,812$ \\
\hline $3 \mathrm{C}$ & CLEAN CLOSE-DISPOSALATTHE UC1 CENIRAL MUD PT & N/A & $\$ 45,639$ & $\$ 52,684$ & $\$ 73,819$ & $\$ 10,415$ & $\$ \mathbf{1 4 4 , 2 6 7}$ & $\$ 31,549$ & $\$ 369,772$ & $\$ 73,819$ & $\$ 369,772$ & $\$ 38,594$ & $\$ 24,505$ & $\$ 456,040$ \\
\hline 4 & ALTERNATIVE IV-BIOREMEDIATION & & & & & & & & & & & & & \\
\hline $4 \mathrm{~A}$ & LAND FARMING & $\$ 3,930,287$ & $\$ 107,761$ & $\$ 114,806$ & $\$ 171,896$ & $\$ 21,492$ & $\$ 356,344$ & $\$ 26,492$ & $\$ 1,024,381$ & $\$ 155,896$ & $\$ 947,932$ & $\$ 51,644$ & $\$ 28,492$ & $\$ 758,035$ \\
\hline $4 \mathrm{~B}$ & In Situ & $\$ 1,308,281$ & $\$ 136,477$ & $\$ 166,477$ & $\$ 481,477$ & $\$ 52,653$ & $\$ 509,508$ & $\$ 95,447$ & $\$ 747,143$ & $\$ 136,477$ & $\$ 722,082$ & $\$ 97,653$ & $\$ 41,447$ & $\$ 195,447$ \\
\hline
\end{tabular}




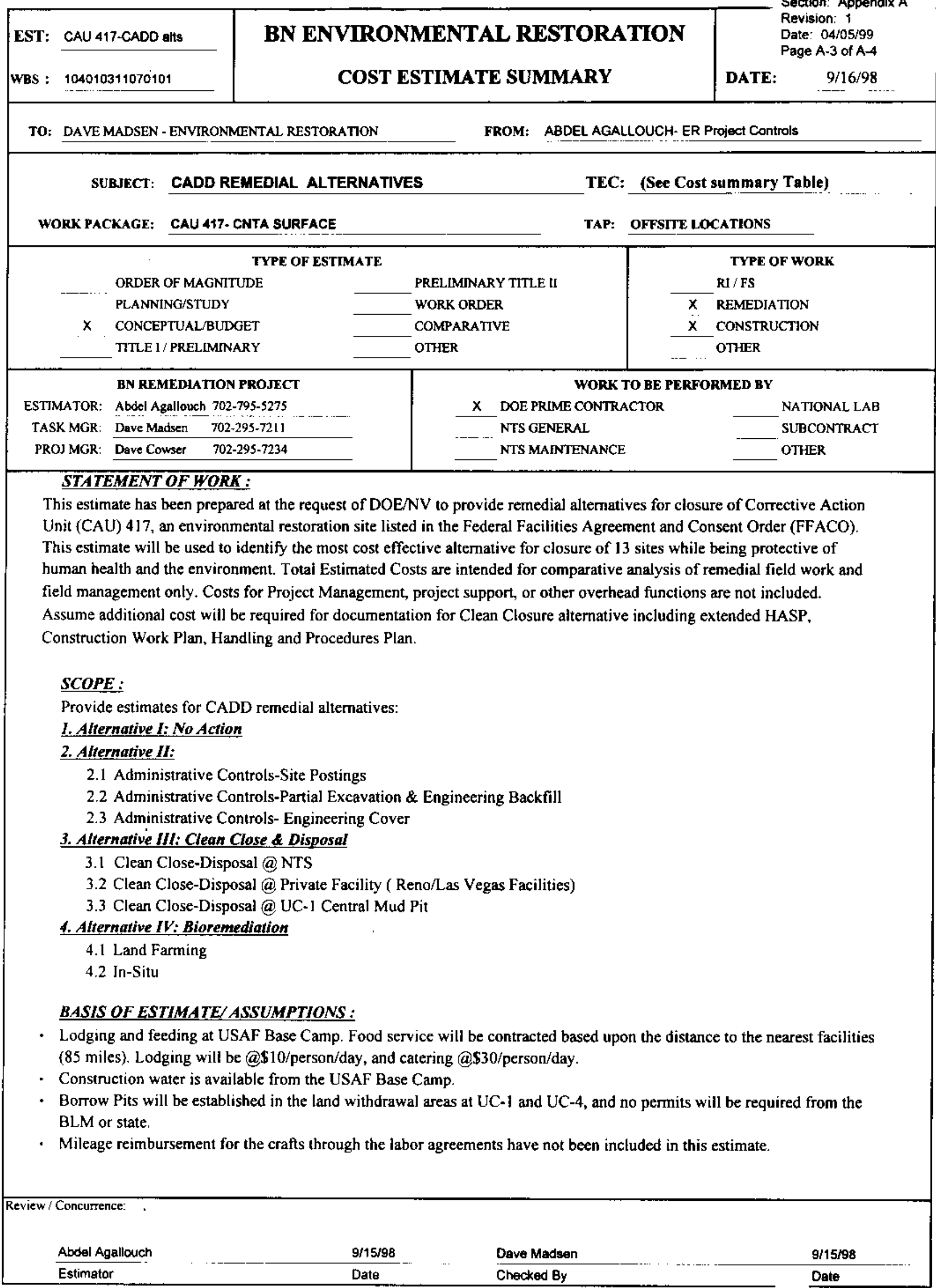


- For UC4 mudpit field work, it is assumed that NTS teamsters and transit trucks will be used. Welded wire mesh concrete and shotcrete will be used in to control degradation. A 30 mil liner will be placed below liner to prevent infiltration. Assume a total volume of $1370 \mathrm{CY}$ of concrete will be needed.

- For Disposal@ @ NT, assume contract transporter@ \$2.75/mile for a total of 520 miles roundtrip. Assume a capacity for the truck of about $16 \mathrm{CY}$. The labor \& equipment to load each truck is approximately $\$ 75 /$ Truck.

- The disposal process includes: excavate, stockpile, maintain roads, haui and place backfilt, regrade areas, transport and dispose of material @NTS

- For Disposal @ private facility ( Las Vegas or Reno ), assume contract transporter@ \$2.75/mile for a total of 500 miles roundtrip for Las Vegas and 600 miles roundtrip for Reno. Assume a capacity for the truck of about $16 \mathrm{CY}$. The labor $\&$ equipment to load each truck is approximately $\$ 75 /$ Truck. The cost range for disposal ranges from $\$ 165$ to $\$ 307 / \mathrm{CY}$.

- The disposal process includes: excavate, stockpile, maintain roads, haul and place backfill, regrade areas, transport and dispose of material @ Private Facility.

- Assume mixing and reconditioning processes for the bioremediation/Landfarming alternative @ the Central Mudpit wi]l have a duration of 1.5 years

- The In-Situ bioremediation alternative entails the following: 1) Conduct a pilot study $\&$ design, 2) Install cover, 3) lnstall horizontal system , 4) System testing, operations and maintenance.

ESCALATION:

Escalation is not included in this estimate. All costs are in FY98 dollars.

CONTINGENCY:

Contingency costs are not included in this estimate.

RATES

FY98 indirect rates, effective $5 / 25 / 98$ were applied using the BN FY98 cost model. 
Revision: 1

Date: $04 / 05 / 99$

Page B-1 of B-4

\section{Appendix B}

\section{Evaluation of Risk}

Because the only contaminant is total petroleum hydrocarbons an A-K determination was prepared instead of a risk assessment. 


\section{A-K Determination for UC-1 Area Contamination}

a) The depth to groundwater. The depth to groundwater in this area is about $168 \mathrm{~m}(535 \mathrm{ft})$.

b) The distance to irrigation wells or wells for drinking water. The nearest well is UCE-18 which was used for a water supply well during activities at the site. The well is located approximately $5.8 \mathrm{~km}(3.6 \mathrm{mi})$ southeast of ground zero at UC-1 and is currently used as a stock well. However, this well is located on the opposite side of the valley and cross gradient from UC-1. The next closest well is the 6 Mile stock well located approximately 14 $\mathrm{km}(8.8 \mathrm{mi})$ south of the UC-1 site.

c) The type of soil that is contaminated. The materials contaminated at the UC-3 area are the alluvial soils of the Breko-Veet-Handpah Association and drill cuttings and mud. The Breko-Veet-Handpah Association generally consists of gravelly, cobbly, or stony loams derived from mixed alluvial sources. Permeability is moderately slow in this soil type.

d) The annual precipitation. The annual precipitation in the Hot Creek Valley is 13 to $15 \mathrm{~cm}$ ( 5 to 6 in.) and the annual evaporation rate is 147 to $168 \mathrm{~cm}$ (58 to 60 in.).

e) The type of waste or substance that was released. Total petroleum hydrocarbon was the only contaminant that was found which exceeded the state regulatory limit of $100 \mathrm{mg} / \mathrm{kg}$.

f) The extent of the contamination. Five separate areas (including the central mud pit) are contaminated with petroleum hydrocarbons in the area of UC-1. The smallest area comprises only $23 \mathrm{~m}^{3}\left(30 \mathrm{yd}^{3}\right)$ and the largest $39,943 \mathrm{~m}^{3}\left(52,556 \mathrm{yd}^{3}\right)$. The total volume of all five areas is $42,219 \mathrm{~m}^{3}\left(55,551 \mathrm{yd}^{3}\right)$ extending to a maximum depth of $1.8 \mathrm{~m}(6 \mathrm{ft})$. All of the contaminated areas are exposed at the surface in the UC-1 area.

g) The present and potential use for the land. The present land use is for cattle grazing and recreation (hunting, camping). This is not expected to change.

h) The preferred routes of migration. The only migration route is transport with precipitation runoff and infiltration. This is very limited because of the low annual rainfall and the high evaporation rate. Wind dispersion is another possibility but based on sampling results this has not occurred in the last 30 years so is not likely to become a driving force for migration of the contaminants.

i) The location of structures or impediments. The only structure of interest for this site is the subsidence boundary fault which intersects the southeast boarder of the Central Mud Pit. This structure could act as either a dam for any potential migration or it could act as a conduit for any potential migration.

j) The potential for a hazard related to fire, vapor, or an explosion. None.

k) Any other information specifically related to the site which the director determines is appropriate. The site is located $104 \mathrm{~km}(65 \mathrm{mi})$ from the nearest town, Tonopah, Nevada. 


\section{A-K Determination for UC-3 Area Contamination}

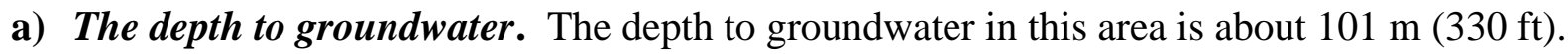

b) The distance to irrigation wells or wells for drinking water. The nearest well is UCE-18, which was used for a water supply well during activities at the site. The well is located approximately $2.6 \mathrm{~km}(1.6 \mathrm{mi})$ southeast of the UC-3 emplacement hole and is currently used as a stock well. However, this well is located on the opposite side of the valley and cross gradient from UC-3. The next closest well is the 6 Mile stock well located approximately $9.6 \mathrm{~km}(6 \mathrm{mi})$ south of the UC-3 site.

c) The type of soil that is contaminated. The materials contaminated at the UC-3 area are the alluvial soils of the Koyen-Unsel Association and drill cuttings and mud. The Koyen-Unsel Association generally consists of gravelly sandy loam derived from mixed alluvial sources. Permeability is moderately rapid in this soil type.

d) The annual precipitation. The annual precipitation in the Hot Creek Valley is 13 to $15 \mathrm{~cm}$ ( 5 to 6 in.) and the annual evaporation rate is 147 to $168 \mathrm{~cm}$ (58 to 60 in.).

e) The type of waste or substance that was released. Total petroleum hydrocarbon was the only contaminant that was found which exceeded the state regulatory limit of $100 \mathrm{mg} / \mathrm{kg}$.

f) The extent of the contamination. Five separate areas are contaminated with petroleum hydrocarbons in the immediate vicinity of UC-3. The smallest area comprises only $11 \mathrm{~m}^{3}$ $\left(15 \mathrm{yd}^{3}\right)$ and the largest $8,512 \mathrm{~m}^{3}\left(11,200 \mathrm{yd}^{3}\right)$. The total volume of all five areas is $11,131 \mathrm{~m}^{3}\left(14,646 \mathrm{yd}^{3}\right)$ extending to a maximum depth of $6.7 \mathrm{~m}(22 \mathrm{ft})$; however, most of the contamination occurs at $2.4 \mathrm{~m}(8 \mathrm{ft})$ or less. Three of the areas are exposed at the surface

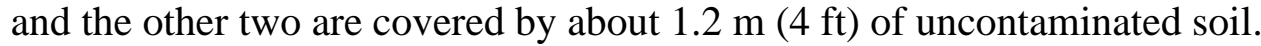

g) The present and potential use for the land. The present land use is for cattle grazing and recreation (hunting, camping). This is not expected to change.

h) The preferred routes of migration. The only migration route is transport with precipitation runoff and infiltration. This is very limited because of the low annual rainfall and the high evaporation rate. Wind dispersion is another possibility but based on sampling results this has not occurred in the last 30 years so is not likely to become a driving force for migration of the contaminants.

i) The location of structures or impediments. None.

j) The potential for a hazard related to fire, vapor, or an explosion. None.

k) Any other information specifically related to the site which the director determines is appropriate. The site is located $104 \mathrm{~km}(65 \mathrm{mi})$ from the nearest town, Tonopah, Nevada. 


\section{A-K Determination for UC-4 Area Contamination}

a) The depth to groundwater. The depth to groundwater in this area is about $163 \mathrm{~m}(535 \mathrm{ft})$.

b) The distance to irrigation wells or wells for drinking water. The nearest well is UCE-18 which was used for a water supply well during activities at the site. The well is located approximately $10.4 \mathrm{~km}(6.5 \mathrm{mi})$ southeast of the UC-4 emplacement hole and is currently used as a stock well. However, this well is located on the opposite side of the valley. The next closest well is the 6 Mile stock well located approximately $14.6 \mathrm{~km}(9.1 \mathrm{mi})$ south of the UC-4 site. There is a spring at Moores Station, located approximately $3.2 \mathrm{~km}$ (2 mi) upgradient from UC-4 and on the opposite side of the valley.

c) The type of soil that is contaminated. The materials contaminated at the UC-4 area are the Morbench soils and drill cuttings and mud. The Morbench soils generally consist of gravelly sandy loam derived from mixed alluvial sources. This soil is moderately permeable.

d) The annual precipitation. The annual precipitation in the Hot Creek Valley is 13 to $15 \mathrm{~cm}$ (5 to 6 in.) and the annual evaporation rate is 147 to $168 \mathrm{~cm}$ (58 to 60 in.).

e) The type of waste or substance that was released. Total petroleum hydrocarbon was the only contaminant that was found which exceeded the state regulatory limit of $100 \mathrm{mg} / \mathrm{kg}$.

f) The extent of the contamination. Seven separate areas are contaminated with petroleum hydrocarbons in the immediate vicinity of UC-4. The smallest area comprises only $90 \mathrm{~m}^{3}$ $\left(118 \mathrm{yd}^{3}\right)$ and the largest $8,107 \mathrm{~m}^{3}\left(10,667 \mathrm{yd}^{3}\right)$. The total volume of all seven areas is $15,222 \mathrm{~m}\left(20,029 \mathrm{yd}^{3}\right)$ extending to a maximum depth of $3 \mathrm{~m}(10 \mathrm{ft})$. Two of the areas are exposed at the surface and the other five are covered by .6 to $1.8 \mathrm{~m} \mathrm{(2} \mathrm{to} 6 \mathrm{ft})$ of uncontaminated soil.

g) The present and potential use for the land. The present land use is for cattle grazing and recreation (hunting, camping). This is not expected to change.

h) The preferred routes of migration. The only migration route is transport with precipitation runoff and infiltration. This is very limited because of the low annual rainfall and the high evaporation rate. Wind dispersion is another possibility but based on sampling results this has not occurred in the last 30 years so is not likely to become a driving force for migration of the contaminants.

i) The location of structures or impediments. None.

j) The potential for a hazard related to fire, vapor, or an explosion. None.

k) Any other information specifically related to the site which the director determines is appropriate. The site is located $104 \mathrm{~km}(65 \mathrm{mi})$ from the nearest town, Tonopah, Nevada. 
Revision: 1

Date: 04/05/99

Page C- 1 of C-14

\section{Appendix C}

\section{Comparative Evaluation of Alternatives}




\section{Table C-1}

Comparative Evaluation of Alternatives

\section{(Page 1 of 13)}

\begin{tabular}{|c|c|}
\hline \multicolumn{2}{|r|}{ Comparative Evaluation of Alternatives for CAS 58-09-01 (UC-1 Central Mud Pit [CMP]) } \\
\hline Evaluation Criteria & Comparative Evaluation \\
\hline \multicolumn{2}{|r|}{ Closure Standards } \\
\hline $\begin{array}{l}\text { Protection of Human Health } \\
\text { and the Environment }\end{array}$ & $\begin{array}{l}\text { Alternative } 1 \text { does not meet closure objective. All other alternatives meet the closure objectives with low risk levels since the COPC concentrations are not } \\
\text { significantly high (maximum of } 2,560 \mathrm{mg} / \mathrm{kg} \mathrm{TPH} \text { ). The impacted area extends from the existing surface to an approximate depth of } 6 \text { feet. No vegetation is } \\
\text { present within the area of impact and the surface has a low load bearing capacity. }\end{array}$ \\
\hline $\begin{array}{l}\text { Compliance with Media } \\
\text { Cleanup Standards }\end{array}$ & $\begin{array}{l}\text { Alternative } 1 \text { does not comply because COPCs remain above the regulatory limits and no controls are implemented to prevent access to the COPCs. All other } \\
\text { alternatives comply. Alternative } 2 \mathrm{~A} \text { complies by providing warnings which would reduce exposure pathways even though COPCs remain above the regulatory } \\
\text { limits. }\end{array}$ \\
\hline $\begin{array}{l}\text { Control the Source(s) of the } \\
\text { Release }\end{array}$ & $\begin{array}{l}\text { Alternatives } 1 \text { and } 2 \mathrm{~A} \text { do not control the release source of COPCs. Natural attenuation and degradation of COPCs can occur but these rates has not been } \\
\text { determined. All other alternatives control the release source: Alternative } 2 \mathrm{C} \text { by reducing infiltration with an engineered cover and the other alternatives by } \\
\text { removing or degrading the COPCs. However, Alternatives } 2 \mathrm{~B} \text { and } 3 \mathrm{ABC} \text { have the potential for release of COPCs during excavation and transportation. }\end{array}$ \\
\hline $\begin{array}{l}\text { Comply with Applicable } \\
\text { Federal, State, and Local } \\
\text { Standards for Waste } \\
\text { Management }\end{array}$ & $\begin{array}{l}\text { All waste generated by any alternative will be managed and disposed per applicable standards. Alternatives } 1 \text { and } 2 \mathrm{~A} \text { are not expected to generate waste. } \\
\text { Alternative } 2 \mathrm{BC} \text { and } 4 \mathrm{AB} \text { may generate some waste. Alternative } 3 \mathrm{ABC} \text { could generate approximately } 52,566 \text { cubic yards of waste. }\end{array}$ \\
\hline \multicolumn{2}{|r|}{ Remedy-Selection Decision Factors } \\
\hline $\begin{array}{l}\text { Short-Term Reliability and } \\
\text { Effectiveness }\end{array}$ & $\begin{array}{l}\text { Alternative } 1 \text { does not institute any controls to mitigate current risks. All other alternatives have at least a potential for worker exposure associated with waste } \\
\text { handling and operation of heavy equipment, and include risk mitigation by following established and site-specific health and safety procedures. Alternatives } \\
2 B C \text { and } 3 A B C \text { have a potential for public exposure associated with waste transportation. The field construction activities for Alternatives } 2 A B C \text { and } 3 A B C \\
\text { could potentially be implemented in less than one month. The field activities for Alternative } 4 A B \text { may be completed within approximately } 1 \text { year for landfarming } \\
\text { and possibly as soon as } 3 \text { years for in situ bioremediation although degradation rates have not been determined. }\end{array}$ \\
\hline $\begin{array}{l}\text { Reduction of Toxicity, Mobility, } \\
\text { and/or Volume }\end{array}$ & $\begin{array}{l}\text { Alternatives } 1 \text { and } 2 A C \text { can reduce the three parameters slowly through natural attenuation although degradation rates have not been determined. Alternatives } \\
2 B, 3 A B C \text {, and } 4 A B \text { will result in more rapid reduction or removal of all three parameters. }\end{array}$ \\
\hline $\begin{array}{l}\text { Long-Term Reliability and } \\
\text { Effectiveness }\end{array}$ & Residual risk for all alternatives is low. Alternatives $2 \mathrm{ABC}$ and $4 \mathrm{~A}$ may require long-term monitoring and maintenance. \\
\hline Feasibility & $\begin{array}{l}\text { Alternative } 1 \text { is not feasible since the it does not meet the media cleanup standards. All other alternatives are feasible. Alternatives } 2 \mathrm{~B} \text { and } 2 \mathrm{C} \text { could pose } \\
\text { engineering problems for construction and maintenance of a cover in an arroyo. Alternative } 3 \mathrm{C} \text { may require an Environmental Assessment. Alternatives } 4 \mathrm{~A} \\
\text { and } 4 \mathrm{~B} \text { may require air discharge and/or treatment permits. Implementation of the alternatives will require coordination with the stakeholders. }\end{array}$ \\
\hline Cost & $\begin{array}{l}\text { The cost for Alternative } 1 \text { is } \$ 0 \text {. The cost for Alternative } 2 A \text { is } \$ 5,415,2 B \text { is } \$ 178,087 \text {, and } 2 C \text { for } \$ 541,485 \text {. Partial excavation was costed assuming } 11,141 \\
\text { cubic yards would be excavated for disposal at the UC-1 CMP. The costs for Alternative } 3 A \text { is } \$ 7,919,151,3 B \text { is } \$ 11,320,802 \text { to } \$ 18,782,104 \text {, and } 3 C \text { is } N / A \text {. } \\
\text { The costs for Alternative } 4 A \text { is } \$ 3,930,287 \text { and } 4 B \text { is } \$ 1,308,281 \text {. }\end{array}$ \\
\hline
\end{tabular}

Alternative 1 is no action. Alternative 2 is administrative controls: $2 \mathrm{~A}$ is site postings only; $2 \mathrm{~B}$ is partial excavation and engineered backfill; and $2 \mathrm{C}$ is an engineered cover. Alternative 3 is clean closure and disposal: $3 \mathrm{~A}$ is disposal at NTS; $3 \mathrm{~B}$ is disposal at a private facility; and $3 \mathrm{C}$ is disposal at the CMP. Alternative 4 is bioremediation: $4 \mathrm{~A}$ is landfarming; and 4B is in situ. 
Table C-1

\section{Comparative Evaluation of Alternatives}

\section{(Page 2 of 13)}

\begin{tabular}{|c|c|}
\hline \multicolumn{2}{|r|}{ Comparative Evaluation of Alternatives for CAS 58-09-02 (UC-1 Mud Pit U1A) } \\
\hline Evaluation Criteria & Comparative Evaluation \\
\hline \multicolumn{2}{|r|}{ Closure Standards } \\
\hline $\begin{array}{l}\text { Protection of Human Health } \\
\text { and the Environment }\end{array}$ & $\begin{array}{l}\text { Alternative } 1 \text { does not meet closure objective. All other alternatives meet the closure objectives with low risk levels since the COPC concentrations are not } \\
\text { significantly high (maximum of } 710 \mathrm{mg} / \mathrm{kg} \mathrm{TPH} \text { ). The impacted area extends from the existing surface to an approximate depth of } 4 \text { feet. Moderate vegetation } \\
\text { is present within the impacted area. }\end{array}$ \\
\hline $\begin{array}{l}\text { Compliance with Media } \\
\text { Cleanup Standards }\end{array}$ & $\begin{array}{l}\text { Alternative } 1 \text { does not comply because COPCs remain above the regulatory limits and no controls are implemented to prevent access to the COPCs. All other } \\
\text { alternatives comply. Alternative } 2 \mathrm{~A} \text { complies by providing warnings which would reduce exposure pathways even though COPCs remain above the regulatory } \\
\text { limits. }\end{array}$ \\
\hline $\begin{array}{l}\text { Control the Source(s) of the } \\
\text { Release }\end{array}$ & $\begin{array}{l}\text { Alternatives } 1 \text { and } 2 \mathrm{~A} \text { do not control the release source of COPCs. Natural attenuation and degradation of COPCs can occur but these rates has not been } \\
\text { determined. All other alternatives control the release source: Alternative } 2 \mathrm{C} \text { by reducing infiltration with an engineered cover and the other alternatives by } \\
\text { removing or degrading the COPCs. However, Alternatives } 2 \mathrm{~B} \text { and } 3 \mathrm{ABC} \text { have the potential for release of COPCs during excavation and transportation. }\end{array}$ \\
\hline $\begin{array}{l}\text { Comply with Applicable } \\
\text { Federal, State, and Local } \\
\text { Standards for Waste } \\
\text { Management }\end{array}$ & $\begin{array}{l}\text { All waste generated by any alternative will be managed and disposed per applicable standards. Alternatives } 1 \text { and } 2 \mathrm{~A} \text { are not expected to generate waste. } \\
\text { Alternative } 2 B C \text { and } 4 A B \text { may generate some waste. Alternative } 3 A B C \text { could generate approximately } 711 \text { cubic yards of waste. }\end{array}$ \\
\hline \multicolumn{2}{|r|}{ Remedy-Selection Decision Factors } \\
\hline $\begin{array}{l}\text { Short-Term Reliability and } \\
\text { Effectiveness }\end{array}$ & $\begin{array}{l}\text { Alternative } 1 \text { does not institute any controls to mitigate current risks. All other alternatives have at least a potential for worker exposure associated with waste } \\
\text { handling and operation of heavy equipment, and include risk mitigation by following established and site-specific health and safety procedures. Alternatives } \\
2 B C \text { and } 3 A B C \text { have a potential for public exposure associated with waste transportation. The field construction activities for Alternatives } 2 A B C \text { and } 3 A B C \\
\text { could potentially be implemented in less than one month. The field activities for Alternative } 4 A B \text { may be completed within approximately } 1 \text { year for landfarming } \\
\text { and possibly as soon as } 2 \text { years for in situ bioremediation although degradation rates have not been determined. }\end{array}$ \\
\hline $\begin{array}{l}\text { Reduction of Toxicity, Mobility, } \\
\text { and/or Volume }\end{array}$ & $\begin{array}{l}\text { Alternatives } 1 \text { and } 2 A C \text { can reduce the three parameters slowly through natural attenuation although degradation rates have not been determined. Alternatives } \\
2 B, 3 A B C \text {, and } 4 A B \text { will result in more rapid reduction or removal of all three parameters. }\end{array}$ \\
\hline $\begin{array}{l}\text { Long-Term Reliability and } \\
\text { Effectiveness }\end{array}$ & Residual risk for all alternatives is low. Alternatives $2 \mathrm{ABC}$ and $4 \mathrm{~A}$ may require long-term monitoring and maintenance. \\
\hline Feasibility & $\begin{array}{l}\text { Alternative } 1 \text { is not feasible since the it does not meet the media cleanup standards. All other alternatives are feasible. Alternative } 3 \mathrm{C} \text { may require an } \\
\text { Environmental Assessment. Alternatives } 4 \mathrm{~A} \text { and } 4 \mathrm{~B} \text { may require air discharge and/or treatment permits. Implementation of the alternatives will require } \\
\text { coordination with the stakeholders. }\end{array}$ \\
\hline Cost & $\begin{array}{l}\text { The cost for Alternative } 1 \text { is } \$ 0 \text {. The cost for Alternative } 2 A \text { is } \$ 2,929,2 B \text { is } \$ 23,669 \text {, and } 2 C \text { for } \$ 103,110 \text {. Partial excavation was costed assuming } 150 \text { cubic } \\
\text { yards would be excavated for disposal at the UC-1 CMP. The costs for Alternative } 3 A \text { is } \$ 115,424,3 B \text { is } \$ 161,815 \text { to } \$ 262,777 \text {, and } 3 C \text { is } \$ 45,639 \text {. The costs } \\
\text { for Alternative } 4 A \text { is } \$ 107,761 \text { and } 4 B \text { is } \$ 136,477 \text {. }\end{array}$ \\
\hline
\end{tabular}

Alternative 1 is no action. Alternative 2 is administrative controls: $2 \mathrm{~A}$ is site postings only; $2 \mathrm{~B}$ is partial excavation and engineered backfill; and $2 \mathrm{C}$ is an engineered cover. Alternative 3 is clean closure and disposal: $3 \mathrm{~A}$ is disposal at NTS; $3 \mathrm{~B}$ is disposal at a private facility; and $3 \mathrm{C}$ is disposal at the CMP. Alternative 4 is bioremediation: $4 \mathrm{~A}$ is landfarming; and 4B is in situ. 
Table C-1

\section{Comparative Evaluation of Alternatives}

\section{(Page 3 of 13)}

\begin{tabular}{|c|c|}
\hline \multicolumn{2}{|r|}{ Comparative Evaluation of Alternatives for CAS 58-09-03 (UC-4 Mud Pits U4A, U4B, U4C, and U4D) } \\
\hline Evaluation Criteria & Comparative Evaluation \\
\hline \multicolumn{2}{|r|}{ Closure Standards } \\
\hline $\begin{array}{l}\text { Protection of Human Health } \\
\text { and the Environment }\end{array}$ & $\begin{array}{l}\text { Alternative } 1 \text { does not meet closure objective. All other alternatives meet the closure objectives with low risk levels since the COPC concentrations are not } \\
\text { significantly high and the impacted areas are at the surface or shallow surface. The maximum TPH concentrations are } 336 \mathrm{mg} / \mathrm{kg} \text { (Mud Pit U4A), } 248.1 \mathrm{mg} / \mathrm{kg} \\
\text { (Mud Pit U4B), } 985 \mathrm{mg} / \mathrm{kg} \text { (Mud Pit U4C), and } 1,700 \mathrm{mg} / \mathrm{kg} \text { (Mud Pit U4D). For Mud Pits U4A, U4B, and U4D, the impacted areas begin } 4 \text { to } 6 \text { feet below the } \\
\text { surface and extend to a maximum depth of } 10 \text { feet. For Mud Pit U4C, the impacted area extends from the surface to an approximate depth of } 2 \text { feet. Abundant } \\
\text { to moderate vegetation is present in the areas of surface and subsurface impact. }\end{array}$ \\
\hline $\begin{array}{l}\text { Compliance with Media } \\
\text { Cleanup Standards }\end{array}$ & $\begin{array}{l}\text { Alternative } 1 \text { does not comply because COPCs remain above the regulatory limits and no controls are implemented to prevent access to the COPCs. All other } \\
\text { alternatives comply. Alternative } 2 \mathrm{~A} \text { complies by providing warnings which would reduce exposure pathways even though COPCs remain above the regulatory } \\
\text { limits. }\end{array}$ \\
\hline $\begin{array}{l}\text { Control the Source(s) of the } \\
\text { Release }\end{array}$ & $\begin{array}{l}\text { Alternatives } 1 \text { and } 2 \mathrm{~A} \text { do not control the release source of COPCs. Natural attenuation and degradation of COPCs can occur but these rates has not been } \\
\text { determined. All other alternatives control the release source: Alternative } 2 \mathrm{C} \text { by reducing infiltration with an engineered cover and the other alternatives by } \\
\text { removing or degrading the COPCs. However, Alternatives } 2 \mathrm{~B} \text { and } 3 \mathrm{ABC} \text { have the potential for release of COPCs during excavation and transportation. }\end{array}$ \\
\hline $\begin{array}{l}\text { Comply with Applicable } \\
\text { Federal, State, and Local } \\
\text { Standards for Waste } \\
\text { Management }\end{array}$ & $\begin{array}{l}\text { All waste generated by any alternative will be managed and disposed per applicable standards. Alternatives } 1 \text { and } 2 \mathrm{~A} \text { are not expected to generate waste. } \\
\text { Alternative } 2 \mathrm{BC} \text { and } 4 \mathrm{AB} \text { may generate some waste. Alternative } 3 \mathrm{ABC} \text { could generate approximately } 8,770 \text { cubic yards of waste. In addition, a considerable } \\
\text { volume of nonimpacted soil would be required to be removed from Mud Pits U4A, U4B, and U4D prior to removing impacted materials. }\end{array}$ \\
\hline \multicolumn{2}{|r|}{ Remedy-Selection Decision Factors } \\
\hline $\begin{array}{l}\text { Short-Term Reliability and } \\
\text { Effectiveness }\end{array}$ & $\begin{array}{l}\text { Alternative } 1 \text { does not institute any controls to mitigate current risks. All other alternatives have at least a potential for worker exposure associated with waste } \\
\text { handling and operation of heavy equipment, and include risk mitigation by following established and site-specific health and safety procedures. Alternatives } \\
2 B C \text { and } 3 A B C \text { have a potential for public exposure associated with waste transportation. The field construction activities for Alternatives } 2 A B C \text { and } 3 A B C \\
\text { could potentially be implemented in less than one month. The field activities for Alternative } 4 A B \text { may be completed within approximately } 1 \text { year for landfarming } \\
\text { and possibly as soon as } 2 \text { years for in situ bioremediation although degradation rates have not been determined. }\end{array}$ \\
\hline $\begin{array}{l}\text { Reduction of Toxicity, Mobility, } \\
\text { and/or Volume }\end{array}$ & $\begin{array}{l}\text { Alternatives } 1 \text { and } 2 A C \text { can reduce the three parameters slowly through natural attenuation although degradation rates have not been determined. Alternatives } \\
2 B, 3 A B C \text {, and } 4 A B \text { will result in more rapid reduction or removal of all three parameters. }\end{array}$ \\
\hline $\begin{array}{l}\text { Long-Term Reliability and } \\
\text { Effectiveness }\end{array}$ & Residual risk for all alternatives is low. Alternatives $2 A B C$ and $4 \mathrm{~A}$ may require long-term monitoring and maintenance. \\
\hline Feasibility & $\begin{array}{l}\text { Alternative } 1 \text { is not feasible since the it does not meet the media cleanup standards. All other alternatives are feasible. Alternative } 3 C \text { may require an } \\
\text { Environmental Assessment. Alternatives } 4 \mathrm{~A} \text { and } 4 \mathrm{~B} \text { may require air discharge and/or treatment permits. Implementation of the alternatives will require } \\
\text { coordination with the stakeholders. }\end{array}$ \\
\hline Cost & $\begin{array}{l}\text { The cost for Alternative } 1 \text { is } \$ 0 \text {. The cost for Alternative } 2 A \text { is } \$ 5,415,2 B \text { is } \$ 72,664 \text {, and } 2 C \text { for } \$ 92,941 \text {. Partial excavation was costed assuming - UC4 was } \\
\text { the only mud pit excavated and } 1,400 \text { cubic yards would be excavated for disposal at the UC-1 CMP. The costs for Alternative } 3 A \text { is } \$ 1,350,998,3 B \text { is } \\
\$ 3,165,812 \text { to } \$ 4,612,862 \text {, and } 3 C \text { is } \$ 456,040 \text {. The costs for Alternative } 4 A \text { is } \$ 758,035 \text { and } 4 B \text { is } \$ 195,447 \text {. }\end{array}$ \\
\hline
\end{tabular}

Alternative 1 is no action. Alternative 2 is administrative controls: $2 \mathrm{~A}$ is site postings only; $2 \mathrm{~B}$ is partial excavation and engineered backfill; and $2 \mathrm{C}$ is an engineered cover. Alternative 3 is clean closure and disposal: $3 \mathrm{~A}$ is disposal at NTS; $3 \mathrm{~B}$ is disposal at a private facility; and $3 \mathrm{C}$ is disposal at the CMP. Alternative 4 is bioremediation: $4 \mathrm{~A}$ is landfarming; and 4B is in situ. 
Table C-1

\section{Comparative Evaluation of Alternatives}

\section{(Page 4 of 13)}

\begin{tabular}{|c|c|}
\hline \multicolumn{2}{|r|}{ Comparative Evaluation of Alternatives for CAS 58-09-05 (UC-1 Mud Pit U1E) } \\
\hline Evaluation Criteria & Comparative Evaluation \\
\hline \multicolumn{2}{|r|}{ Closure Standards } \\
\hline $\begin{array}{l}\text { Protection of Human Health } \\
\text { and the Environment }\end{array}$ & $\begin{array}{l}\text { Alternative } 1 \text { does not meet closure objective. All other alternatives meet the closure objectives with low risk levels since the COPC concentrations are not } \\
\text { significantly high (maximum of } 632 \mathrm{mg} / \mathrm{kg} \mathrm{TPH} \text { ). The impacted area extends from the existing surface to an approximate depth of } 4 \text { feet. Abundant vegetation } \\
\text { is present within the impacted area. }\end{array}$ \\
\hline $\begin{array}{l}\text { Compliance with Media } \\
\text { Cleanup Standards }\end{array}$ & $\begin{array}{l}\text { Alternative } 1 \text { does not comply because COPCs remain above the regulatory limits and no controls are implemented to prevent access to the COPCs. All other } \\
\text { alternatives comply. Alternative } 2 \mathrm{~A} \text { complies by providing warnings which would reduce exposure pathways even though COPCs remain above the regulatory } \\
\text { limits. }\end{array}$ \\
\hline $\begin{array}{l}\text { Control the Source(s) of the } \\
\text { Release }\end{array}$ & $\begin{array}{l}\text { Alternatives } 1 \text { and } 2 \mathrm{~A} \text { do not control the release source of COPCs. Natural attenuation and degradation of COPCs can occur but these rates have not been } \\
\text { determined. All other alternatives control the release source: Alternative } 2 \mathrm{C} \text { by reducing infiltration with an engineered cover and the other alternatives by } \\
\text { removing or degrading the COPCs. However, Alternatives } 2 \mathrm{~B} \text { and } 3 \mathrm{ABC} \text { have the potential for release of COPCs during excavation and transportation. }\end{array}$ \\
\hline $\begin{array}{l}\text { Comply with Applicable } \\
\text { Federal, State, and Local } \\
\text { Standards for Waste } \\
\text { Management }\end{array}$ & $\begin{array}{l}\text { All waste generated by any alternative will be managed and disposed per applicable standards. Alternatives } 1 \text { and } 2 \mathrm{~A} \text { are not expected to generate waste. } \\
\text { Alternative } 2 \mathrm{~B} \text { could generate approximately } 200 \text { cubic yards of waste. Alternatives } 2 \mathrm{C} \text { and } 4 \mathrm{AB} \text { could generate lesser volumes of waste. Alternatives } 3 \mathrm{~A}, 3 \mathrm{~B} \text {, } \\
\text { and } 3 \mathrm{C} \text { could generate approximately } 832 \text { cubic yards of waste. }\end{array}$ \\
\hline \multicolumn{2}{|r|}{ Remedy-Selection Decision Factors } \\
\hline $\begin{array}{l}\text { Short-Term Reliability and } \\
\text { Effectiveness }\end{array}$ & $\begin{array}{l}\text { Alternative } 1 \text { does not institute any controls to mitigate current risks. All other alternatives have at least a potential for worker exposure associated with waste } \\
\text { handling and operation of heavy equipment, and include risk mitigation by following established and site-specific health and safety procedures. Alternatives } \\
2 \mathrm{BC} \text { and } 3 \mathrm{ABC} \text { have a potential for public exposure associated with waste transportation. The field construction activities for Alternatives } 2 \mathrm{ABC} \text { and } 3 \mathrm{ABC} \\
\text { could potentially be implemented in less than one month. The field activities for Alternative } 4 \mathrm{AB} \text { may be completed within approximately } 1 \text { year for landfarming } \\
\text { and possibly as soon as } 2 \text { years for in situ bioremediation although degradation rates have not been determined. }\end{array}$ \\
\hline $\begin{array}{l}\text { Reduction of Toxicity, Mobility, } \\
\text { and/or Volume }\end{array}$ & $\begin{array}{l}\text { Alternatives } 1 \text { and } 2 A C \text { can reduce the three parameters slowly through natural attenuation although degradation rates have not been determined. Alternatives } \\
2 B, 3 A B C \text {, and } 4 A B \text { will result in more rapid reduction or removal of all three parameters. }\end{array}$ \\
\hline $\begin{array}{l}\text { Long-Term Reliability and } \\
\text { Effectiveness }\end{array}$ & Residual risk for all alternatives is low. Alternatives $2 A B C$ and $4 \mathrm{~A}$ may require long-term monitoring and maintenance. \\
\hline Feasibility & $\begin{array}{l}\text { Alternative } 1 \text { is not feasible since the it does not meet the media cleanup standards. All other alternatives are feasible. Alternative } 3 C \text { may require an } \\
\text { Environmental Assessment. Alternatives } 4 \mathrm{~A} \text { and } 4 \mathrm{~B} \text { may require air discharge and/or treatment permits. Implementation of the alternatives will require } \\
\text { coordination with the stakeholders. }\end{array}$ \\
\hline Cost & $\begin{array}{l}\text { The cost for Alternative } 1 \text { is } \$ 0 \text {. The cost for Alternative } 2 A \text { is } \$ 2,929,2 B \text { is } \$ 23,669 \text {, and } 2 C \text { for } \$ 103,110 \text {. Partial excavation was costed assuming } 200 \text { cubic } \\
\text { yards would be excavated for disposal at the UC-1 CMP. The costs for Alternative } 3 A \text { is } \$ 133,453,3 B \text { is } \$ 187,655 \text { to } \$ 305,799 \text {, and } 3 C \text { is } \$ 52,684 \text {. The costs } \\
\text { for Alternative } 4 A \text { is } \$ 114,806 \text { and } 4 B \text { is } \$ 166,477 \text {. }\end{array}$ \\
\hline
\end{tabular}

Alternative 1 is no action. Alternative 2 is administrative controls: $2 \mathrm{~A}$ is site postings only; $2 \mathrm{~B}$ is partial excavation and engineered backfill; and $2 \mathrm{C}$ is an engineered cover. Alternative 3 is clean closure and disposal: $3 \mathrm{~A}$ is disposal at NTS; $3 \mathrm{~B}$ is disposal at a private facility; and $3 \mathrm{C}$ is disposal at the CMP. Alternative 4 is bioremediation: $4 \mathrm{~A}$ is landfarming; and 4B is in situ. 
Table C-1

\section{Comparative Evaluation of Alternatives}

\begin{tabular}{|c|c|}
\hline \multicolumn{2}{|r|}{ Comparative Evaluation of Alternatives for CAS 58-09-06 (UC-3 Mud Pit E [U3E]) } \\
\hline Evaluation Criteria & Comparative Evaluation \\
\hline \multicolumn{2}{|r|}{ Closure Standards } \\
\hline $\begin{array}{l}\text { Protection of Human Health } \\
\text { and the Environment }\end{array}$ & $\begin{array}{l}\text { Alternative } 1 \text { does not meet closure objective. All other alternatives meet the closure objectives with low risk levels since the COPC concentrations are } \\
\text { predominantly less than the maximum } 15,440 \mathrm{mg} / \mathrm{kg} \mathrm{TPH} \text {. The impacted area extends from the existing surface to an approximate depth of } 10 \text { feet. Abundant } \\
\text { vegetation is present within the impacted area. }\end{array}$ \\
\hline $\begin{array}{l}\text { Compliance with Media } \\
\text { Cleanup Standards }\end{array}$ & $\begin{array}{l}\text { Alternative } 1 \text { does not comply because COPCs remain above the regulatory limits and no controls are implemented to prevent access to the COPCs. All other } \\
\text { alternatives comply. Alternative } 2 \mathrm{~A} \text { complies by providing warnings which would reduce exposure pathways even though COPCs remain above the regulatory } \\
\text { limits. }\end{array}$ \\
\hline $\begin{array}{l}\text { Control the Source }(\mathrm{s}) \text { of the } \\
\text { Release }\end{array}$ & $\begin{array}{l}\text { Alternatives } 1 \text { and } 2 \mathrm{~A} \text { do not control the release source of COPCs. Natural attenuation and degradation of COPCs can occur but these rates have not been } \\
\text { determined. All other alternatives control the release source: Alternative } 2 \mathrm{C} \text { by reducing infiltration with an engineered cover and the other alternatives by } \\
\text { removing or degrading the COPCs. However, Alternatives } 2 \mathrm{~B} \text { and } 3 \mathrm{ABC} \text { have the potential for release of COPCs during excavation and transportation. }\end{array}$ \\
\hline $\begin{array}{l}\text { Comply with Applicable } \\
\text { Federal, State, and Local } \\
\text { Standards for Waste } \\
\text { Management }\end{array}$ & $\begin{array}{l}\text { All waste generated by any alternative will be managed and disposed per applicable standards. Alternatives } 1 \text { and } 2 \mathrm{~A} \text { are not expected to generate waste. } \\
\text { Alternative } 2 \mathrm{~B} \text { could generate approximately } 700 \text { cubic yards of waste. Alternatives } 2 \mathrm{C} \text { and } 4 \mathrm{AB} \text { could generate lesser volumes of waste. Alternatives } 3 \mathrm{~A}, 3 \mathrm{~B} \text {, } \\
\text { and } 3 \mathrm{C} \text { could generate approximately } 2,222 \text { cubic yards of waste. }\end{array}$ \\
\hline \multicolumn{2}{|r|}{ Remedy-Selection Decision Factors } \\
\hline $\begin{array}{l}\text { Short-Term Reliability and } \\
\text { Effectiveness }\end{array}$ & $\begin{array}{l}\text { Alternative } 1 \text { does not institute any controls to mitigate current risks. All other alternatives have at least a potential for worker exposure associated with waste } \\
\text { handling and operation of heavy equipment, and include risk mitigation by following established and site-specific health and safety procedures. Alternatives } \\
2 B C \text { and } 3 A B C \text { have a potential for public exposure associated with waste transportation. The field construction activities for Alternatives } 2 A B C \text { and } 3 A B C \\
\text { could potentially be implemented in less than one month. The field activities for Alternative } 4 A B \text { may be completed within approximately } 1 \text { year for landfarming } \\
\text { and possibly as soon as } 3 \text { years for in situ bioremediation although degradation rates have not been determined. }\end{array}$ \\
\hline $\begin{array}{l}\text { Reduction of Toxicity, Mobility, } \\
\text { and/or Volume }\end{array}$ & $\begin{array}{l}\text { Alternatives } 1 \text { and } 2 A C \text { can reduce the three parameters slowly through natural attenuation although degradation rates have not been determined. Alternatives } \\
2 B, 3 A B C \text {, and } 4 A B \text { will result in more rapid reduction or removal of all three parameters. }\end{array}$ \\
\hline $\begin{array}{l}\text { Long-Term Reliability and } \\
\text { Effectiveness }\end{array}$ & Residual risk for all alternatives is low. Alternatives $2 A B C$ and $4 \mathrm{~A}$ may require long-term monitoring and maintenance. \\
\hline Feasibility & $\begin{array}{l}\text { Alternative } 1 \text { is not feasible since the it does not meet the media cleanup standards. All other alternatives are feasible. Alternative } 3 C \text { may require an } \\
\text { Environmental Assessment. Alternatives } 4 \mathrm{~A} \text { and } 4 \mathrm{~B} \text { may require air discharge and/or treatment permits. Implementation of the alternatives will require } \\
\text { coordination with the stakeholders. }\end{array}$ \\
\hline Cost & $\begin{array}{l}\text { The cost for Alternative } 1 \text { is } \$ 0 \text {. The cost for Alternative } 2 A \text { is } \$ 2,929,2 B \text { is } \$ 54,291 \text {, and } 2 C \text { for } \$ 51,317 \text {. Partial excavation was costed assuming } 700 \text { cubic } \\
\text { yards would be excavated for disposal at the UC-1 CMP. The costs for Alternative } 3 A \text { is } \$ 343,345,3 B \text { is } \$ 796,371 \text { to } \$ 1,163,001 \text {, and } 3 C \text { is } \$ 144,267 \text {. The } \\
\text { costs for Alternative } 4 A \text { is } \$ 356,344 \text { and } 4 B \text { is } \$ 509,508 \text {. }\end{array}$ \\
\hline
\end{tabular}

Alternative 1 is no action. Alternative 2 is administrative controls: $2 \mathrm{~A}$ is site postings only; $2 \mathrm{~B}$ is partial excavation and engineered backfill; and $2 \mathrm{C}$ is an engineered cover. Alternative 3 is clean closure and disposal: $3 \mathrm{~A}$ is disposal at NTS; $3 \mathrm{~B}$ is disposal at a private facility; and $3 \mathrm{C}$ is disposal at the CMP. Alternative 4 is bioremediation: $4 \mathrm{~A}$ is landfarming; and 4B is in situ. 
Table C-1

\section{Comparative Evaluation of Alternatives}

\section{(Page 6 of 13)}

\begin{tabular}{|c|c|}
\hline \multicolumn{2}{|r|}{ Comparative Evaluation of Alternatives for CAS 58-10-01 (UC-3 Shaker Pad Area) } \\
\hline Evaluation Criteria & Comparative Evaluation \\
\hline \multicolumn{2}{|r|}{ Closure Standards } \\
\hline $\begin{array}{l}\text { Protection of Human Health } \\
\text { and the Environment }\end{array}$ & $\begin{array}{l}\text { Alternative } 1 \text { does not meet closure objective. All other alternatives meet the closure objectives with low risk levels since the COPC concentrations are not } \\
\text { significantly high (maximum of } 1,670 \mathrm{mg} / \mathrm{kg} \mathrm{TPH} \text { ). The impacted area extends from approximately } 4 \text { to } 6 \text { feet below the existing surface. Moderate vegetation } \\
\text { is present above the impacted area. }\end{array}$ \\
\hline $\begin{array}{l}\text { Compliance with Media } \\
\text { Cleanup Standards }\end{array}$ & $\begin{array}{l}\text { Alternative } 1 \text { does not comply because COPCs remain above the regulatory limits and no controls are implemented to prevent access to the COPCs. All other } \\
\text { alternatives comply. Alternative } 2 \mathrm{~A} \text { complies by providing warnings which would reduce exposure pathways even though COPCs remain above the regulatory } \\
\text { limits. }\end{array}$ \\
\hline $\begin{array}{l}\text { Control the Source(s) of the } \\
\text { Release }\end{array}$ & $\begin{array}{l}\text { Alternatives } 1 \text { and } 2 \mathrm{~A} \text { do not control the release source of COPCs. Natural attenuation and degradation of COPCs can occur but these rates have not been } \\
\text { determined. All other alternatives control the release source: Alternative } 2 \mathrm{C} \text { by reducing infiltration with an engineered cover and the other alternatives by } \\
\text { removing or degrading the COPCs. However, Alternatives } 2 \mathrm{~B} \text { and } 3 \mathrm{ABC} \text { have the potential for release of COPCs during excavation and transportation. }\end{array}$ \\
\hline $\begin{array}{l}\text { Comply with Applicable } \\
\text { Federal, State, and Local } \\
\text { Standards for Waste } \\
\text { Management }\end{array}$ & $\begin{array}{l}\text { All waste generated by any alternative will be managed and disposed per applicable standards. Alternatives } 1 \text { and } 2 \mathrm{~A} \text { are not expected to generate waste. } \\
\text { Alternatives } 2 \mathrm{~B} \text { and } 3 \mathrm{ABC} \text { could generate approximately } 185 \text { cubic yards of waste. In addition, at least } 400 \text { cubic yards of nonimpacted overburden would be } \\
\text { required to be excavated and removed to access the impacted materials. Alternatives } 2 \mathrm{C} \text { and } 4 \mathrm{AB} \text { could generate lesser volumes of waste. }\end{array}$ \\
\hline \multicolumn{2}{|r|}{ Remedy-Selection Decision Factors } \\
\hline $\begin{array}{l}\text { Short-Term Reliability and } \\
\text { Effectiveness }\end{array}$ & $\begin{array}{l}\text { Alternative } 1 \text { does not institute any controls to mitigate current risks. All other alternatives have at least a potential for worker exposure associated with waste } \\
\text { handling and operation of heavy equipment, and include risk mitigation by following established and site-specific health and safety procedures. Alternatives } \\
2 B C \text { and } 3 A B C \text { have a potential for public exposure associated with waste transportation. The field construction activities for Alternatives } 2 A B C \text { and } 3 A B C \\
\text { could potentially be implemented in less than one month. The field activities for Alternative } 4 A B \text { may be completed within approximately } 1 \text { year for landfarming } \\
\text { and possibly as soon as } 2 \text { years for in situ bioremediation although degradation rates have not been determined. }\end{array}$ \\
\hline $\begin{array}{l}\text { Reduction of Toxicity, Mobility, } \\
\text { and/or Volume }\end{array}$ & $\begin{array}{l}\text { Alternatives } 1 \text { and } 2 A C \text { can reduce the three parameters slowly through natural attenuation although degradation rates have not been determined. Alternatives } \\
2 B, 3 A B C \text {, and } 4 A B \text { will result in more rapid reduction or removal of all three parameters. }\end{array}$ \\
\hline $\begin{array}{l}\text { Long-Term Reliability and } \\
\text { Effectiveness }\end{array}$ & Residual risk for all alternatives is low. Alternatives $2 A B C$ and $4 \mathrm{~A}$ may require long-term monitoring and maintenance. \\
\hline Feasibility & $\begin{array}{l}\text { Alternative } 1 \text { is not feasible since the it does not meet the media cleanup standards. All other alternatives are feasible. Alternative } 3 C \text { may require an } \\
\text { Environmental Assessment. Alternatives } 4 \mathrm{~A} \text { and } 4 \mathrm{~B} \text { may require air discharge and/or treatment permits. Implementation of the alternatives will require } \\
\text { coordination with the stakeholders. }\end{array}$ \\
\hline Cost & $\begin{array}{l}\text { The cost for Alternative } 1 \text { is } \$ 0 \text {. The cost for Alternative } 2 A \text { is } \$ 1,604,2 B \text { is } \$ 35,918 \text {, and } 2 C \text { for } \$ 29,990 \text {. Partial excavation was costed assuming } 400 \text { cubic } \\
\text { yards would be excavated for disposal at the UC-1 CMP. The costs for Alternative } 3 A \text { is } \$ 28,054,3 B \text { is } \$ 66,041 \text { to } \$ 96,566 \text {, and } 3 C \text { is } \$ 31,549 \text {. The costs for } \\
\text { Alternative } 4 A \text { is } \$ 26,492 \text { and } 4 B \text { is } \$ 95,447 \text {. }\end{array}$ \\
\hline
\end{tabular}

Alternative 1 is no action. Alternative 2 is administrative controls: $2 \mathrm{~A}$ is site postings only; $2 \mathrm{~B}$ is partial excavation and engineered backfill; and $2 \mathrm{C}$ is an engineered cover. Alternative 3 is clean closure and disposal: $3 \mathrm{~A}$ is disposal at NTS; $3 \mathrm{~B}$ is disposal at a private facility; and $3 \mathrm{C}$ is disposal at the CMP. Alternative 4 is bioremediation: $4 \mathrm{~A}$ is landfarming; and 4B is in situ. 
Table C-1

\section{Comparative Evaluation of Alternatives}

\section{(Page 7 of 13)}

\begin{tabular}{|c|c|}
\hline \multicolumn{2}{|r|}{ Comparative Evaluation of Alternatives for CAS 58-10-02 (UC-4 Shaker Pad Area [U4S]) } \\
\hline Evaluation Criteria & Comparative Evaluation \\
\hline \multicolumn{2}{|r|}{ Closure Standards } \\
\hline $\begin{array}{l}\text { Protection of Human Health } \\
\text { and the Environment }\end{array}$ & $\begin{array}{l}\text { Alternative } 1 \text { does not meet closure objective. All other alternatives meet the closure objectives with low risk levels since the COPC concentrations are not } \\
\text { significantly high (maximum of } 1,015 \mathrm{mg} / \mathrm{kg} \text { TPH). The impacted area extends from } 2 \mathrm{ft} \text { below the existing surface to an approximate depth of } 6 \text { feet. Sparse to } \\
\text { moderate vegetation is present in the impacted area and is attributed to the absence of soil/nutrients which would sustain plant growth. }\end{array}$ \\
\hline $\begin{array}{l}\text { Compliance with Media } \\
\text { Cleanup Standards }\end{array}$ & $\begin{array}{l}\text { Alternative } 1 \text { does not comply because COPCs remain above the regulatory limits and no controls are implemented to prevent access to the COPCs. All other } \\
\text { alternatives comply. Alternative } 2 \mathrm{~A} \text { complies by providing warnings which would reduce exposure pathways even though COPCs remain above the regulatory } \\
\text { limits. }\end{array}$ \\
\hline $\begin{array}{l}\text { Control the Source(s) of the } \\
\text { Release }\end{array}$ & $\begin{array}{l}\text { Alternatives } 1 \text { and } 2 \mathrm{~A} \text { do not control the release source of COPCs. Natural attenuation and degradation of COPCs can occur but these rates have not been } \\
\text { determined. All other alternatives control the release source: Alternative } 2 \mathrm{C} \text { by reducing infiltration with an engineered cover and the other alternatives by } \\
\text { removing or degrading the COPCs. However, Alternatives } 2 \mathrm{~B} \text { and } 3 \mathrm{ABC} \text { have the potential for release of COPCs during excavation and transportation. }\end{array}$ \\
\hline $\begin{array}{l}\text { Comply with Applicable } \\
\text { Federal, State, and Local } \\
\text { Standards for Waste } \\
\text { Management }\end{array}$ & $\begin{array}{l}\text { All waste generated by any alternative will be managed and disposed per applicable standards. Alternatives } 1 \text { and } 2 \mathrm{~A} \text { are not expected to generate waste. } \\
\text { Alternatives } 2 \mathrm{~B} \text { could generate approximately } 1,000 \text { cubic yards of waste. Alternatives } 2 \mathrm{C} \text { and } 4 \mathrm{AB} \text { could generate lesser volumes of waste. Alternatives } 3 \mathrm{~A} \text {, } \\
3 \mathrm{~B} \text {, and } 3 \mathrm{C} \text { could generate approximately } 10,667 \text { cubic yards of waste. }\end{array}$ \\
\hline \multicolumn{2}{|r|}{ Remedy-Selection Decision Factors } \\
\hline $\begin{array}{l}\text { Short-Term Reliability and } \\
\text { Effectiveness }\end{array}$ & $\begin{array}{l}\text { Alternative } 1 \text { does not institute any controls to mitigate current risks. All other alternatives have at least a potential for worker exposure associated with waste } \\
\text { handling and operation of heavy equipment, and include risk mitigation by following established and site-specific health and safety procedures. Alternatives } \\
2 B C \text { and } 3 A B C \text { have a potential for public exposure associated with waste transportation. The field construction activities for Alternatives } 2 A B C \text { and } 3 A B C \\
\text { could potentially be implemented in less than one month. The field activities for Alternative } 4 A B \text { may be completed within approximately } 1 \text { year for landfarming } \\
\text { and possibly as soon as } 2 \text { years for in situ bioremediation although degradation rates have not been determined. }\end{array}$ \\
\hline $\begin{array}{l}\text { Reduction of Toxicity, Mobility, } \\
\text { and/or Volume }\end{array}$ & $\begin{array}{l}\text { Alternatives } 1 \text { and } 2 A C \text { can reduce the three parameters slowly through natural attenuation although degradation rates have not been determined. Alternatives } \\
2 B, 3 A B C \text {, and } 4 A B \text { will result in more rapid reduction or removal of all three parameters. }\end{array}$ \\
\hline $\begin{array}{l}\text { Long-Term Reliability and } \\
\text { Effectiveness }\end{array}$ & Residual risk for all alternatives is low. Alternatives $2 A B C$ and $4 A$ may require long-term monitoring and maintenance. \\
\hline Feasibility & $\begin{array}{l}\text { Alternative } 1 \text { is not feasible since the it does not meet the media cleanup standards. All other alternatives are feasible although the construction of the } \\
\text { Alternative } 2 \mathrm{C} \text { cover in a drainage channel may reduce its feasibility. Alternative } 3 \mathrm{C} \text { may require an Environmental Assessment. Alternatives } 4 \mathrm{~A} \text { and } 4 \mathrm{~B} \text { may } \\
\text { require air discharge and/or treatment permits as well as substantial drainage diversion until the bioremediation is complete, which reduces the feasibility. } \\
\text { Implementation of the alternatives will require coordination with the stakeholders. }\end{array}$ \\
\hline Cost & $\begin{array}{l}\text { The cost for Alternative } 1 \text { is } \$ 0 \text {. The cost for Alternative } 2 A \text { is } \$ 2,929,2 B \text { is } \$ 72,664 \text {, and } 2 C \text { for } \$ 244,847 \text {. Partial excavation was costed assuming } \\
1,000 \text { cubic yards would be excavated for disposal at the UC-1 CMP. The costs for Alternative } 3 A \text { is } \$ 1,657,173,3 B \text { is } \$ 3,865,704 \text { to } \$ 5,625,759 \text {, and } 3 C \text { is } \\
\$ 369,772 \text {. The costs for Alternative } 4 A \text { is } \$ 947,932 \text { and } 4 B \text { is } \$ 722,082 \text {. }\end{array}$ \\
\hline
\end{tabular}

Alternative 1 is no action. Alternative 2 is administrative controls: $2 \mathrm{~A}$ is site postings only; $2 \mathrm{~B}$ is partial excavation and engineered backfill; and $2 \mathrm{C}$ is an engineered cover. Alternative 3 is clean closure and disposal: $3 \mathrm{~A}$ is disposal at NTS; $3 \mathrm{~B}$ is disposal at a private facility; and $3 \mathrm{C}$ is disposal at the CMP. Alternative 4 is bioremediation: $4 \mathrm{~A}$ is landfarming; and 4B is in situ. 
Table C-1

\section{Comparative Evaluation of Alternatives}

\section{(Page 8 of 13)}

\begin{tabular}{|c|c|}
\hline \multicolumn{2}{|r|}{ Comparative Evaluation of Alternatives for CAS 58-10-03 (UC-1 Shaker Pad Area) } \\
\hline Evaluation Criteria & Comparative Evaluation \\
\hline \multicolumn{2}{|r|}{ Closure Standards } \\
\hline $\begin{array}{l}\text { Protection of Human Health } \\
\text { and the Environment }\end{array}$ & $\begin{array}{l}\text { Alternative } 1 \text { does not meet closure objective. All other alternatives meet the closure objectives with low risk levels since the COPC concentrations are not } \\
\text { significantly high (maximum of } 4,500 \mathrm{mg} / \mathrm{kg} \mathrm{TPH} \text { ). The impacted area extends from the existing surface to an approximate depth of } 4 \text { feet. Sparse vegetation } \\
\text { in the impacted area is attributed to the absence of soil/nutrients which would sustain plant growth. }\end{array}$ \\
\hline $\begin{array}{l}\text { Compliance with Media } \\
\text { Cleanup Standards }\end{array}$ & $\begin{array}{l}\text { Alternative } 1 \text { does not comply because COPCs remain above the regulatory limits and no controls are implemented to prevent access to the COPCs. All other } \\
\text { alternatives comply. Alternative } 2 \mathrm{~A} \text { complies by providing warnings which would reduce exposure pathways even though COPCs remain above the regulatory } \\
\text { limits. }\end{array}$ \\
\hline $\begin{array}{l}\text { Control the Source }(\mathrm{s}) \text { of the } \\
\text { Release }\end{array}$ & $\begin{array}{l}\text { Alternatives } 1 \text { and } 2 \mathrm{~A} \text { do not control the release source of COPCs. Natural attenuation and degradation of COPCs can occur but these rates have not been } \\
\text { determined. All other alternatives control the release source: Alternative } 2 \mathrm{C} \text { by reducing infiltration with an engineered cover and the other alternatives by } \\
\text { removing or degrading the COPCs. However, Alternatives } 2 \mathrm{~B} \text { and } 3 \mathrm{ABC} \text { have the potential for release of COPCs during excavation and transportation. }\end{array}$ \\
\hline $\begin{array}{l}\text { Comply with Applicable } \\
\text { Federal, State, and Local } \\
\text { Standards for Waste } \\
\text { Management }\end{array}$ & $\begin{array}{l}\text { All waste generated by any alternative will be managed and disposed per applicable standards. Alternatives } 1 \text { and } 2 \mathrm{~A} \text { are not expected to generate waste. } \\
\text { Alternative } 2 \mathrm{~B} \text { could generate approximately } 1,200 \text { cubic yards of waste. Alternatives } 2 \mathrm{C} \text { and } 4 \mathrm{AB} \text { could generate lesser volumes of waste. Alternatives } 3 \mathrm{~A} \text {, } \\
3 \mathrm{~B} \text {, and } 3 \mathrm{C} \text { could generate approximately } 1,422 \text { cubic yards of waste. }\end{array}$ \\
\hline \multicolumn{2}{|r|}{ Remedy-Selection Decision Factors } \\
\hline $\begin{array}{l}\text { Short-Term Reliability and } \\
\text { Effectiveness }\end{array}$ & $\begin{array}{l}\text { Alternative } 1 \text { does not institute any controls to mitigate current risks. All other alternatives have at least a potential for worker exposure associated with waste } \\
\text { handling and operation of heavy equipment, and include risk mitigation by following established and site-specific health and safety procedures. Alternatives } \\
2 B C \text { and } 3 A B C \text { have a potential for public exposure associated with waste transportation. The field construction activities for Alternatives } 2 A B C \text { and } 3 A B C \\
\text { could potentially be implemented in less than one month. The field activities for Alternative } 4 A B \text { may be completed within approximately } 1 \text { year for landfarming } \\
\text { and possibly as soon as } 3 \text { years for in situ bioremediation although degradation rates have not been determined. }\end{array}$ \\
\hline $\begin{array}{l}\text { Reduction of Toxicity, Mobility, } \\
\text { and/or Volume }\end{array}$ & $\begin{array}{l}\text { Alternatives } 1 \text { and } 2 A C \text { can reduce the three parameters slowly through natural attenuation although degradation rates have not been determined. Alternatives } \\
2 B, 3 A B C \text {, and } 4 A B \text { will result in more rapid reduction or removal of all three parameters. }\end{array}$ \\
\hline $\begin{array}{l}\text { Long-Term Reliability and } \\
\text { Effectiveness }\end{array}$ & Residual risk for all alternatives is low. Alternatives $2 \mathrm{ABC}$ and $4 \mathrm{~A}$ may require long-term monitoring and maintenance. \\
\hline Feasibility & $\begin{array}{l}\text { Alternative } 1 \text { is not feasible since the it does not meet the media cleanup standards. All other alternatives are feasible. Alternative } 3 \mathrm{C} \text { may require an } \\
\text { Environmental Assessment. Alternatives } 4 \mathrm{~A} \text { and } 4 \mathrm{~B} \text { may require air discharge and/or treatment permits. Implementation of the alternatives will require } \\
\text { coordination with the stakeholders. }\end{array}$ \\
\hline Cost & $\begin{array}{l}\text { The cost for Alternative } 1 \text { is } \$ 0 \text {. The cost for Alternative } 2 A \text { is } \$ 2,929,2 B \text { is } \$ 84,913 \text {, and } 2 C \text { for } \$ 162,436 \text {. Partial excavation was costed assuming } 400 \text { cubic } \\
\text { yards would be excavated for disposal at the UC- } 1 \text { CMP. The costs for Alternative } 3 A \text { is } \$ 205,701,3 B \text { is } \$ 299,756 \text { to } \$ 494,414 \text {, and } 3 C \text { is } \$ 73,819 \text {. The costs } \\
\text { for Alternative } 4 A \text { is } \$ 171,896 \text { and } 4 B \text { is } \$ 481,477 \text {. }\end{array}$ \\
\hline
\end{tabular}

Alternative 1 is no action. Alternative 2 is administrative controls: $2 \mathrm{~A}$ is site postings only; $2 \mathrm{~B}$ is partial excavation and engineered backfill; and $2 \mathrm{C}$ is an engineered cover. Alternative 3 is clean closure and disposal: $3 \mathrm{~A}$ is disposal at NTS; $3 \mathrm{~B}$ is disposal at a private facility; and $3 \mathrm{C}$ is disposal at the CMP. Alternative 4 is bioremediation: $4 \mathrm{~A}$ is landfarming; and 4B is in situ. 
Table C-1

\section{Comparative Evaluation of Alternatives}

\section{(Page 9 of 13)}

\begin{tabular}{|c|c|}
\hline \multicolumn{2}{|r|}{ Comparative Evaluation of Alternatives for CAS 58-10-04 (UC-4 Shaker Pad Area [U4W]) } \\
\hline Evaluation Criteria & Comparative Evaluation \\
\hline \multicolumn{2}{|r|}{ Closure Standards } \\
\hline $\begin{array}{l}\text { Protection of Human Health } \\
\text { and the Environment }\end{array}$ & $\begin{array}{l}\text { Alternative } 1 \text { does not meet closure objective. All other alternatives meet the closure objectives with low risk levels since the COPC concentrations are not } \\
\text { significantly high (maximum of } 301.3 \mathrm{mg} / \mathrm{kg} \text { TPH). The impacted area extends from the existing surface to an approximate depth of } 8 \text { feet. Moderate } \\
\text { vegetation is present in the impacted area. }\end{array}$ \\
\hline $\begin{array}{l}\text { Compliance with Media } \\
\text { Cleanup Standards }\end{array}$ & $\begin{array}{l}\text { Alternative } 1 \text { does not comply because COPCs remain above the regulatory limits and no controls are implemented to prevent access to the COPCs. All other } \\
\text { alternatives comply. Alternative } 2 \mathrm{~A} \text { complies by providing warnings which would reduce exposure pathways even though COPCs remain above the regulatory } \\
\text { limits. }\end{array}$ \\
\hline $\begin{array}{l}\text { Control the Source(s) of the } \\
\text { Release }\end{array}$ & $\begin{array}{l}\text { Alternatives } 1 \text { and } 2 \mathrm{~A} \text { do not control the release source of COPCs. Natural attenuation and degradation of COPCs can occur but these rates have not been } \\
\text { determined. All other alternatives control the release source: Alternative } 2 \mathrm{C} \text { by reducing infiltration with an engineered cover and the other alternatives by } \\
\text { removing or degrading the COPCs. However, Alternatives } 2 \mathrm{~B} \text { and } 3 \mathrm{ABC} \text { have the potential for release of COPCs during excavation and transportation. }\end{array}$ \\
\hline $\begin{array}{l}\text { Comply with Applicable } \\
\text { Federal, State, and Local } \\
\text { Standards for Waste } \\
\text { Management }\end{array}$ & $\begin{array}{l}\text { All waste generated by any alternative will be managed and disposed per applicable standards. Alternatives } 1 \text { and } 2 \mathrm{~A} \text { are not expected to generate waste. } \\
\text { Alternative } 2 \mathrm{~B} \text { could generate approximately } 200 \text { cubic yards of waste. Alternatives } 2 \mathrm{C} \text { and } 4 \mathrm{AB} \text { could generate lesser volumes of waste. Alternatives } 3 \mathrm{~A}, 3 \mathrm{~B} \text {, } \\
\text { and } 3 \mathrm{C} \text { could generate approximately } 474 \text { cubic yards of waste. }\end{array}$ \\
\hline \multicolumn{2}{|r|}{ Remedy-Selection Decision Factors } \\
\hline $\begin{array}{l}\text { Short-Term Reliability and } \\
\text { Effectiveness }\end{array}$ & $\begin{array}{l}\text { Alternative } 1 \text { does not institute any controls to mitigate current risks. All other alternatives have at least a potential for worker exposure associated with waste } \\
\text { handling and operation of heavy equipment, and include risk mitigation by following established and site-specific health and safety procedures. Alternatives } \\
2 B C \text { and } 3 A B C \text { have a potential for public exposure associated with waste transportation. The field construction activities for Alternatives } 2 A B C \text { and } 3 A B C \\
\text { could potentially be implemented in less than one month. The field activities for Alternative } 4 A B \text { may be completed within approximately } 1 \text { year for landfarming } \\
\text { and possibly as soon as } 2 \text { years for in situ bioremediation although degradation rates have not been determined. }\end{array}$ \\
\hline $\begin{array}{l}\text { Reduction of Toxicity, Mobility, } \\
\text { and/or Volume }\end{array}$ & $\begin{array}{l}\text { Alternatives } 1 \text { and } 2 A C \text { can reduce the three parameters slowly through natural attenuation although degradation rates have not b een determined. Alternatives } \\
2 B, 3 A B C \text {, and } 4 A B \text { will result in more rapid reduction or removal of all three parameters. }\end{array}$ \\
\hline $\begin{array}{l}\text { Long-Term Reliability and } \\
\text { Effectiveness }\end{array}$ & Residual risk for all alternatives is low. Alternatives $2 \mathrm{ABC}$ and $4 \mathrm{~A}$ may require long-term monitoring and maintenance. \\
\hline Feasibility & $\begin{array}{l}\text { Alternative } 1 \text { is not feasible since the it does not meet the media cleanup standards. All other alternatives are feasible although the construction of the } \\
\text { Alternative } 2 \mathrm{C} \text { cover in a drainage channel may reduce its feasibility. Alternative } 3 \mathrm{C} \text { may require an Environmental Assessment. Alternatives } 4 \mathrm{~A} \text { and } 4 \mathrm{~B} \text { may } \\
\text { require air discharge and/or treatment permits. Implementation of the alternatives will require coordination with the stakeholders. }\end{array}$ \\
\hline Cost & $\begin{array}{l}\text { The cost for Alternative } 1 \text { is } \$ 0 \text {. The cost for Alternative } 2 A \text { is } \$ 2,929,2 B \text { is } \$ 23,669 \text {, and } 2 C \text { for } \$ 57,332 \text {. Partial excavation was costed assuming } 200 \text { cubic } \\
\text { yards would be excavated for disposal at the UC-1 CMP. The costs for Alternative } 3 A \text { is } \$ 74,443,3 B \text { is } \$ 172,391 \text { to } \$ 250,601 \text {, and } 3 C \text { is } \$ 38,594 \text {. The costs } \\
\text { for Alternative } 4 A \text { is } \$ 51,644 \text { and } 4 B \text { is } \$ 97,653 \text {. }\end{array}$ \\
\hline
\end{tabular}

Alternative 1 is no action. Alternative 2 is administrative controls: $2 \mathrm{~A}$ is site postings only; $2 \mathrm{~B}$ is partial excavation and engineered backfill; and $2 \mathrm{C}$ is an engineered cover. Alternative 3 is clean closure and disposal: $3 \mathrm{~A}$ is disposal at NTS; $3 \mathrm{~B}$ is disposal at a private facility; and $3 \mathrm{C}$ is disposal at the CMP. Alternative 4 is bioremediation: $4 \mathrm{~A}$ is landfarming; and 4B is in situ. 
Table C-1

\section{Comparative Evaluation of Alternatives}

\section{(Page 10 of 13)}

\begin{tabular}{|c|c|}
\hline \multicolumn{2}{|r|}{ Comparative Evaluation of Alternatives for CAS 58-10-05 (UC-4 Shaker Pad Area [U4X]) } \\
\hline Evaluation Criteria & Comparative Evaluation \\
\hline \multicolumn{2}{|r|}{ Closure Standards } \\
\hline $\begin{array}{l}\text { Protection of Human Health } \\
\text { and the Environment }\end{array}$ & $\begin{array}{l}\text { Alternative } 1 \text { does not meet closure objective. All other alternatives meet the closure objectives with low risk levels since the COPC concentrations are not } \\
\text { significantly high (maximum of } 131.2 \mathrm{mg} / \mathrm{kg} \text { TPH), the impacted area is subsurface and extends from approximately } 4 \text { to } 6 \text { feet below the existing ground } \\
\text { surface, and abundant vegetation is present over the impacted area. }\end{array}$ \\
\hline $\begin{array}{l}\text { Compliance with Media } \\
\text { Cleanup Standards }\end{array}$ & $\begin{array}{l}\text { Alternative } 1 \text { does not comply because COPCs remain above the regulatory limits and no controls are implemented to prevent access to the COPCs. All other } \\
\text { alternatives comply. Alternative } 2 \mathrm{~A} \text { complies by providing warnings which would reduce exposure pathways even though COPCs remain above the regulatory } \\
\text { limits. }\end{array}$ \\
\hline $\begin{array}{l}\text { Control the Source }(\mathrm{s}) \text { of the } \\
\text { Release }\end{array}$ & $\begin{array}{l}\text { Alternatives } 1 \text { and } 2 \mathrm{~A} \text { do not control the release source of COPCs. Natural attenuation and degradation of COPCs can occur but these rates have not been } \\
\text { determined. All other alternatives control the release source: Alternative } 2 \mathrm{C} \text { by reducing infiltration with an engineered cover and the other alternatives by } \\
\text { removing or degrading the COPCs. However, Alternatives } 2 \mathrm{~B} \text { and } 3 \mathrm{ABC} \text { have the potential for release of COPCs during excavation and transportation. }\end{array}$ \\
\hline $\begin{array}{l}\text { Comply with Applicable } \\
\text { Federal, State, and Local } \\
\text { Standards for Waste } \\
\text { Management }\end{array}$ & $\begin{array}{l}\text { All waste generated by any alternative will be managed and disposed per applicable standards. Alternatives } 1 \text { and } 2 \mathrm{~A} \text { are not expected to generate waste. } \\
\text { Alternatives } 2 \mathrm{~B}, 3 \mathrm{~A}, 3 \mathrm{~B} \text {, and } 3 \mathrm{C} \text { could generate approximately } 118 \text { cubic yards of waste. In addition, at least } 240 \text { cubic yards of non-impacted material would } \\
\text { require removal in order to excavate the waste. Alternatives } 2 \mathrm{C} \text { and } 4 \mathrm{AB} \text { could generate lesser volumes of waste. }\end{array}$ \\
\hline \multicolumn{2}{|r|}{ Remedy-Selection Decision Factors } \\
\hline $\begin{array}{l}\text { Short-Term Reliability and } \\
\text { Effectiveness }\end{array}$ & $\begin{array}{l}\text { Alternative } 1 \text { does not institute any controls to mitigate current risks. All other alternatives have at least a potential for worker exposure associated with waste } \\
\text { handling and operation of heavy equipment, and include risk mitigation by following established and site-specific health and safety procedures. Alternatives } \\
2 B C \text { and } 3 A B C \text { have a potential for public exposure associated with waste transportation. The field construction activities for Alternatives } 2 A B C \text { and } 3 A B C \\
\text { could potentially be implemented in less than one month. The field activities for Alternative } 4 A B \text { may be completed within approximately } 1 \text { year for landfarming } \\
\text { and possibly as soon as } 2 \text { years for in situ bioremediation although degradation rates have not been determined. }\end{array}$ \\
\hline $\begin{array}{l}\text { Reduction of Toxicity, Mobility, } \\
\text { and/or Volume }\end{array}$ & $\begin{array}{l}\text { Alternatives } 1 \text { and } 2 A C \text { can reduce the three parameters slowly through natural attenuation although degradation rates have not been determined. Alternatives } \\
2 B, 3 A B C \text {, and } 4 A B \text { will result in more rapid reduction or removal of all three parameters. }\end{array}$ \\
\hline $\begin{array}{l}\text { Long-Term Reliability and } \\
\text { Effectiveness }\end{array}$ & Residual risk for all alternatives is low. Alternatives $2 \mathrm{ABC}$ and $4 \mathrm{~A}$ may require long-term monitoring and maintenance. \\
\hline Feasibility & $\begin{array}{l}\text { Alternative } 1 \text { is not feasible since the it does not meet the media cleanup standards. All other alternatives are feasible. Alternative } 3 \mathrm{C} \text { may require an } \\
\text { Environmental Assessment. Alternatives } 4 \mathrm{~A} \text { and } 4 \mathrm{~B} \text { may require air discharge and/or treatment permits. Implementation of the alternatives will require } \\
\text { coordination with the stakeholders. }\end{array}$ \\
\hline Cost & $\begin{array}{l}\text { The cost for Alternative } 1 \text { is } \$ 0 \text {. The cost for Alternative } 2 A \text { is } \$ 2,929,2 B \text { is } \$ 29,793 \text {, and } 2 C \text { for } \$ 35,271 \text {. Partial excavation was costed assuming } 400 \text { cubic } \\
\text { yards would be excavated for disposal at the UC-1 CMP. The costs for Alternative } 3 A \text { is } \$ 21,086,3 B \text { is } \$ 45,472 \text { to } \$ 65,212 \text {, and } 3 C \text { is } \$ 24,505 \text {. The costs for } \\
\text { Alternative } 4 A \text { is } \$ 28,492 \text { and } 4 B \text { is } \$ 41,447 \text {. }\end{array}$ \\
\hline
\end{tabular}

Alternative 1 is no action. Alternative 2 is administrative controls: $2 \mathrm{~A}$ is site postings only; $2 \mathrm{~B}$ is partial excavation and engineered backfill; and $2 \mathrm{C}$ is an engineered cover. Alternative 3 is clean closure and disposal: $3 \mathrm{~A}$ is disposal at NTS; $3 \mathrm{~B}$ is disposal at a private facility; and $3 \mathrm{C}$ is disposal at the CMP. Alternative 4 is bioremediation: $4 \mathrm{~A}$ is landfarming; and 4B is in situ. 
Table C-1

\section{Comparative Evaluation of Alternatives}

\section{(Page 11 of 13)}

\begin{tabular}{|c|c|}
\hline \multicolumn{2}{|r|}{ Comparative Evaluation of Alternatives for CAS 58-25-01 (UC-3 Spill Southern Outlier [U3E]) } \\
\hline Evaluation Criteria & Comparative Evaluation \\
\hline \multicolumn{2}{|r|}{ Closure Standards } \\
\hline $\begin{array}{l}\text { Protection of Human Health } \\
\text { and the Environment }\end{array}$ & $\begin{array}{l}\text { Alternative } 1 \text { does not meet closure objective. All other alternatives meet the closure objectives with low risk levels since the COPC concentrations are not } \\
\text { significantly high (maximum of } 17,010 \mathrm{mg} / \mathrm{kg} \mathrm{TPH} \text { ). The impacted area extends from the existing surface to an approximate depth of } 22 \text { feet. Abundant } \\
\text { vegetation is present over the impacted area. }\end{array}$ \\
\hline $\begin{array}{l}\text { Compliance with Media } \\
\text { Cleanup Standards }\end{array}$ & $\begin{array}{l}\text { Alternative } 1 \text { does not comply because COPCs remain above the regulatory limits and no controls are implemented to prevent access to the COPCs. All other } \\
\text { alternatives comply. Alternative } 2 \mathrm{~A} \text { complies by providing warnings which would reduce exposure pathways even though COPCs remain above the regulatory } \\
\text { limits. }\end{array}$ \\
\hline $\begin{array}{l}\text { Control the Source(s) of the } \\
\text { Release }\end{array}$ & $\begin{array}{l}\text { Alternatives } 1 \text { and } 2 \mathrm{~A} \text { do not control the release source of COPCs. Natural attenuation and degradation of COPCs can occur but these rates have not been } \\
\text { determined. All other alternatives control the release source: Alternative } 2 \mathrm{C} \text { by reducing infiltration with an engineered cover and the other alternatives by } \\
\text { removing or degrading the COPCs. However, Alternatives } 2 \mathrm{~B} \text { and } 3 \mathrm{ABC} \text { have the potential for release of COPCs during excavation and transportation. }\end{array}$ \\
\hline $\begin{array}{l}\text { Comply with Applicable } \\
\text { Federal, State, and Local } \\
\text { Standards for Waste } \\
\text { Management }\end{array}$ & $\begin{array}{l}\text { All waste generated by any alternative will be managed and disposed per applicable standards. Alternatives } 1 \text { and } 2 \mathrm{~A} \text { are not expected to generate waste. } \\
\text { Alternatives } 3 \mathrm{~A}, 3 \mathrm{~B} \text {, and } 3 \mathrm{C} \text { could generate } 11,200 \text { cubic yards of waste. Alternatives } 2 \mathrm{BC} \text { and } 4 \mathrm{AB} \text { could generate lesser volumes of waste. }\end{array}$ \\
\hline \multicolumn{2}{|r|}{ Remedy-Selection Decision Factors } \\
\hline $\begin{array}{l}\text { Short-Term Reliability and } \\
\text { Effectiveness }\end{array}$ & $\begin{array}{l}\text { Alternative } 1 \text { does not institute any controls to mitigate current risks. All other alternatives have at least a potential for worker exposure associated with waste } \\
\text { handling and operation of heavy equipment, and include risk mitigation by following established and site-specific health and safety procedures. Alternatives } \\
2 B C \text { and } 3 A B C \text { have a potential for public exposure associated with waste transportation. The field construction activities for Alternatives } 2 A B C \text { and } 3 A B C \\
\text { could potentially be implemented in less than one month. The field activities for Alternative } 4 A B \text { may be completed within approximately } 1 \text { year for landfarming } \\
\text { and possibly as soon as } 3 \text { years for in situ bioremediation although degradation rates have not been determined. }\end{array}$ \\
\hline $\begin{array}{l}\text { Reduction of Toxicity, Mobility, } \\
\text { and/or Volume }\end{array}$ & $\begin{array}{l}\text { Alternatives } 1 \text { and } 2 A C \text { can reduce the three parameters slowly through natural attenuation although degradation rates have not been determined. Alternatives } \\
2 B, 3 A B C \text {, and } 4 A B \text { will result in more rapid reduction or removal of all three parameters. }\end{array}$ \\
\hline $\begin{array}{l}\text { Long-Term Reliability and } \\
\text { Effectiveness }\end{array}$ & Residual risk for all alternatives is low. Alternatives $2 \mathrm{ABC}$ and $4 \mathrm{~A}$ may require long-term monitoring and maintenance. \\
\hline Feasibility & $\begin{array}{l}\text { Alternative } 1 \text { is not feasible since the it does not meet the media cleanup standards. All other alternatives are feasible. Alternative } 3 \mathrm{C} \text { may require an } \\
\text { Environmental Assessment. Alternatives } 4 \mathrm{~A} \text { and } 4 \mathrm{~B} \text { may require air discharge and/or treatment permits. Implementation of the alternatives will require } \\
\text { coordination with the stakeholders. }\end{array}$ \\
\hline Cost & $\begin{array}{l}\text { The cost for Alternative } 1 \text { is } \$ 0 \text {. The cost for Alternative } 2 A \text { is } \$ 2,929,2 B \text { is } \$ 195,152 \text {, and } 2 C \text { for } \$ 78,393 \text {. Partial excavation was costed assuming } \\
3,000 \text { cubic yards would be excavated for disposal at the UC- } 1 \text { CMP. The costs for Alternative } 3 A \text { is } \$ 1,767,048 \text {, } 3 B \text { is } \$ 4,088,091 \text { to } \$ 5,936,091 \text {, and } 3 C \text { is } \\
\$ 848,752 \text {. The costs for Alternative } 4 A \text { is } \$ 1,024,381 \text { and } 4 B \text { is } \$ 747,143 \text {. }\end{array}$ \\
\hline
\end{tabular}

Alternative 1 is no action. Alternative 2 is administrative controls: $2 \mathrm{~A}$ is site postings only; $2 \mathrm{~B}$ is partial excavation and engineered backfill; and $2 \mathrm{C}$ is an engineered cover. Alternative 3 is clean closure and disposal: $3 \mathrm{~A}$ is disposal at NTS; $3 \mathrm{~B}$ is disposal at a private facility; and $3 \mathrm{C}$ is disposal at the CMP. Alternative 4 is bioremediation: $4 \mathrm{~A}$ is landfarming; and 4B is in situ. 
Table C-1

\section{Comparative Evaluation of Alternatives}

\section{(Page 12 of 13)}

\begin{tabular}{|c|c|}
\hline \multicolumn{2}{|r|}{ Comparative Evaluation of Alternatives for CAS 58-44-03 (UC-3 Drill Mud/Grout Spill [U3Z]) } \\
\hline Evaluation Criteria & Comparative Evaluation \\
\hline \multicolumn{2}{|r|}{ Closure Standards } \\
\hline $\begin{array}{l}\text { Protection of Human Health } \\
\text { and the Environment }\end{array}$ & $\begin{array}{l}\text { Alternative } 1 \text { does not meet closure objective. All other alternatives meet the closure objectives with low risk levels since the COPC concentrations are low } \\
\text { (maximum of } 676 \mathrm{mg} / \mathrm{kg} \mathrm{TPH} \text { ). The impacted area extends from the existing surface to an approximate depth of } 2 \text { feet. Sparse vegetation over the impacted } \\
\text { area is attributed to the absence of soil/nutrients which would sustain plant growth. }\end{array}$ \\
\hline $\begin{array}{l}\text { Compliance with Media } \\
\text { Cleanup Standards }\end{array}$ & $\begin{array}{l}\text { Alternative } 1 \text { does not comply because COPCs remain above the regulatory limits and no controls are implemented to prevent access to the COPCs. All other } \\
\text { alternatives comply. Alternative } 2 \mathrm{~A} \text { complies by providing warnings which would reduce exposure pathways even though COPCs remain above the regulatory } \\
\text { limits. }\end{array}$ \\
\hline $\begin{array}{l}\text { Control the Source }(\mathrm{s}) \text { of the } \\
\text { Release }\end{array}$ & $\begin{array}{l}\text { Alternatives } 1 \text { and } 2 \mathrm{~A} \text { do not control the release source of COPCs. Natural attenuation and degradation of COPCs can occur but these rates have not been } \\
\text { determined. All other alternatives control the release source: Alternative } 2 \mathrm{C} \text { by reducing infiltration with an engineered cover and the other alternatives by } \\
\text { removing or degrading the COPCs. However, Alternatives } 2 \mathrm{~B} \text { and } 3 \mathrm{ABC} \text { have the potential for release of COPCs during excavation and transportation. }\end{array}$ \\
\hline $\begin{array}{l}\text { Comply with Applicable } \\
\text { Federal, State, and Local } \\
\text { Standards for Waste } \\
\text { Management }\end{array}$ & $\begin{array}{l}\text { All waste generated by any alternative will be managed and disposed per applicable standards. Alternatives } 1 \text { and } 2 \mathrm{~A} \text { are not expected to generate waste. } \\
\text { Alternatives } 3 \mathrm{~A}, 3 \mathrm{~B} \text {, and } 3 \mathrm{C} \text { could generate over } 1,000 \text { cubic yards of waste. Alternatives } 2 \mathrm{BC} \text { and } 4 \mathrm{AB} \text { could generate lesser volumes of waste. }\end{array}$ \\
\hline \multicolumn{2}{|r|}{ Remedy-Selection Decision Factors } \\
\hline $\begin{array}{l}\text { Short-Term Reliability and } \\
\text { Effectiveness }\end{array}$ & $\begin{array}{l}\text { Alternative } 1 \text { does not institute any controls to mitigate current risks. All other alternatives have at least a potential for worker exposure associated with waste } \\
\text { handling and operation of heavy equipment, and include risk mitigation by following established and site-specific health and safety procedures. Alternatives } \\
2 B C \text { and } 3 A B C \text { have a potential for public exposure associated with waste transportation. The field construction activities for Alternatives } 2 A B C \text { and } 3 A B C \\
\text { could potentially be implemented in less than one month. The field activities for Alternative } 4 A B \text { may be completed within approximately } 1 \text { year for landfarming } \\
\text { and possibly as soon as } 2 \text { years for in situ bioremediation although degradation rates have not been determined. }\end{array}$ \\
\hline $\begin{array}{l}\text { Reduction of Toxicity, Mobility, } \\
\text { and/or Volume }\end{array}$ & $\begin{array}{l}\text { Alternatives } 1 \text { and } 2 A C \text { can reduce the three parameters slowly through natural attenuation although degradation rates have not been determined. Alternatives } \\
2 B, 3 A B C \text {, and } 4 A B \text { will result in more rapid reduction or removal of all three parameters. }\end{array}$ \\
\hline $\begin{array}{l}\text { Long-Term Reliability and } \\
\text { Effectiveness }\end{array}$ & Residual risk for all alternatives is low. Alternatives $2 \mathrm{ABC}$ and $4 \mathrm{~A}$ may require long-term monitoring and maintenance. \\
\hline Feasibility & $\begin{array}{l}\text { Alternative } 1 \text { is not feasible since the it does not meet the media cleanup standards. All other alternatives are feasible. Alternative } 3 \mathrm{C} \text { may require an } \\
\text { Environmental Assessment. Alternatives } 4 \mathrm{~A} \text { and } 4 \mathrm{~B} \text { may require air discharge and/or treatment permits. Implementation of the alternatives will require } \\
\text { coordination with the stakeholders. }\end{array}$ \\
\hline Cost & $\begin{array}{l}\text { The cost for Alternative } 1 \text { is } \$ 0 \text {. The cost for Alternative } 2 A \text { is } \$ 2,929,2 B \text { is } \$ 17,544 \text {, and } 2 C \text { for } \$ 47,237 \text {. Partial excavation was costed assuming } 400 \text { cubic } \\
\text { yards would be excavated for disposal at the UC- } 1 \text { CMP. The costs for Alternative } 3 A \text { is } \$ 164,309,3 B \text { is } \$ 376,494 \text { to } \$ 545,454 \text {, and } 3 C \text { is } \$ 73,819 \text {. The costs } \\
\text { for Alternative } 4 A \text { is } \$ 155,896 \text { and } 4 B \text { is } \$ 136,477 \text {. }\end{array}$ \\
\hline
\end{tabular}

Alternative 1 is no action. Alternative 2 is administrative controls: $2 \mathrm{~A}$ is site postings only; $2 \mathrm{~B}$ is partial excavation and engineered backfill; and $2 \mathrm{C}$ is an engineered cover. Alternative 3 is clean closure and disposal: $3 \mathrm{~A}$ is disposal at NTS; $3 \mathrm{~B}$ is disposal at a private facility; and $3 \mathrm{C}$ is disposal at the CMP. Alternative 4 is bioremediation: $4 \mathrm{~A}$ is landfarming; and 4B is in situ. 
Table C-1

\section{Comparative Evaluation of Alternatives}

\section{(Page 13 of 13)}

\begin{tabular}{|c|c|}
\hline \multicolumn{2}{|r|}{ Comparative Evaluation of Alternatives for CAS 58-44-06 (UC-1 Borrow Pit) } \\
\hline Evaluation Criteria & Comparative Evaluation \\
\hline \multicolumn{2}{|r|}{ Closure Standards } \\
\hline $\begin{array}{l}\text { Protection of Human Health } \\
\text { and the Environment }\end{array}$ & $\begin{array}{l}\text { Alternative } 1 \text { does not meet closure objective. All other alternatives meet the closure objectives with low risk levels since the COPC concentrations are low } \\
\text { (maximum of } 197.2 \mathrm{mg} / \mathrm{kg} \mathrm{TPH} \text { ). The impacted area extends from the existing surface to an approximate depth of } 2 \text { feet. Abundant vegetation is present over } \\
\text { the impacted area. }\end{array}$ \\
\hline $\begin{array}{l}\text { Compliance with Media } \\
\text { Cleanup Standards }\end{array}$ & $\begin{array}{l}\text { Alternative } 1 \text { does not comply because COPCs remain above the regulatory limits and no controls are implemented to prevent access to the COPCs. All other } \\
\text { alternatives comply. Alternative } 2 \mathrm{~A} \text { complies by providing warnings which would reduce exposure pathways even though COPCs remain above the regulatory } \\
\text { limits. }\end{array}$ \\
\hline $\begin{array}{l}\text { Control the Source }(s) \text { of the } \\
\text { Release }\end{array}$ & $\begin{array}{l}\text { Alternatives } 1 \text { and } 2 \mathrm{~A} \text { do not control the release source of COPCs. Natural attenuation and degradation of COPCs can occur but these rates have not been } \\
\text { determined. All other alternatives control the release source: Alternative } 2 \mathrm{C} \text { by reducing infiltration with an engineered cover and the other alternatives by } \\
\text { removing or degrading the COPCs. However, Alternatives } 2 \mathrm{~B} \text { and } 3 \mathrm{ABC} \text { have the potential for release of COPCs during excavation and transportation. }\end{array}$ \\
\hline $\begin{array}{l}\text { Comply with Applicable } \\
\text { Federal, State, and Local } \\
\text { Standards for Waste } \\
\text { Management }\end{array}$ & $\begin{array}{l}\text { All waste generated by any alternative will be managed and disposed per applicable standards. Alternatives } 1 \text { and } 2 \mathrm{~A} \text { are not expected to generate waste. } \\
\text { Alternatives } 3 \mathrm{~A}, 3 \mathrm{~B} \text {, and } 3 \mathrm{C} \text { could generate } 30 \text { cubic yards of waste. Alternatives } 2 \mathrm{BC} \text { and } 4 \mathrm{AB} \text { could generate lesser volumes of waste. }\end{array}$ \\
\hline \multicolumn{2}{|r|}{ Remedy-Selection Decision Factors } \\
\hline $\begin{array}{l}\text { Short-Term Reliability and } \\
\text { Effectiveness }\end{array}$ & $\begin{array}{l}\text { Alternative } 1 \text { does not institute any controls to mitigate current risks. All other alternatives have at least a potential for worker exposure associated with waste } \\
\text { handling and operation of heavy equipment, and include risk mitigation by following established and site-specific health and safety procedures. Alternatives } \\
2 B C \text { and } 3 A B C \text { have a potential for public exposure associated with waste transportation. The field construction activities for Alternatives } 2 A B C \text { and } 3 A B C \\
\text { could potentially be implemented in less than one week. The field activities for Alternative } 4 A B \text { may be completed within approximately } 6 \text { months for } \\
\text { landfarming and possibly as soon as } 1 \text { year for in situ bioremediation although degradation rates have not been determined. }\end{array}$ \\
\hline $\begin{array}{l}\text { Reduction of Toxicity, Mobility, } \\
\text { and/or Volume }\end{array}$ & $\begin{array}{l}\text { Alternatives } 1 \text { and } 2 A C \text { can reduce the three parameters slowly through natural attenuation although degradation rates have not been determined. Alternatives } \\
2 B, 3 A B C \text {, and } 4 A B \text { will result in more rapid reduction or removal of all three parameters. }\end{array}$ \\
\hline $\begin{array}{l}\text { Long-Term Reliability and } \\
\text { Effectiveness }\end{array}$ & Residual risk for all alternatives is low. Alternatives $2 \mathrm{ABC}$ and $4 \mathrm{~A}$ may require long-term monitoring and maintenance. \\
\hline Feasibility & $\begin{array}{l}\text { Alternative } 1 \text { is not feasible since the it does not meet the media cleanup standards. All other alternatives are feasible. Alternative } 3 \mathrm{C} \text { may require an } \\
\text { Environmental Assessment. Alternatives } 4 \mathrm{~A} \text { and } 4 \mathrm{~B} \text { may require air discharge and/or treatment permits. Implementation of the alternatives will require } \\
\text { coordination with the stakeholders. }\end{array}$ \\
\hline Cost & $\begin{array}{l}\text { The cost for Alternative } 1 \text { is } \$ 0 \text {. The cost for Alternative } 2 A \text { is } \$ 2,929,2 B \text { is } \$ 17,544 \text {, and } 2 C \text { for } \$ 43,983 \text {. The costs for Alternative } 3 A \text { is } \$ 11,934,3 B \text { is } \\
\$ 14,196 \text { to } \$ 18,366 \text {, and } 3 C \text { is } \$ 10,415 \text {. The costs for Alternative } 4 A \text { is } \$ 21,492 \text { and } 4 B \text { is } \$ 52,653 \text {. }\end{array}$ \\
\hline
\end{tabular}

Alternative 1 is no action. Alternative 2 is administrative controls: $2 \mathrm{~A}$ is site postings only; $2 \mathrm{~B}$ is partial excavation and engineered backfill; and $2 \mathrm{C}$ is an engineered cover. Alternative 3 is clean closure and disposal: $3 \mathrm{~A}$ is disposal at NTS; $3 \mathrm{~B}$ is disposal at a private facility; and $3 \mathrm{C}$ is disposal at the CMP. Alternative 4 is bioremediation: 4A is landfarming; and 4B is in situ. 


\section{Distribution List}

$\underline{\text { Copies }}$

2 (Controlled)

Paul J. Liebendorfer

State of Nevada

Bureau of Federal Facilities

Division of Environmental Protection

333 W. Nye Lane, Room 138

Carson City, NV 89706-0851

Michael D. McKinnon

State of Nevada

Bureau of Federal Facilities

Division of Environmental Protection

555 E. Washington, Suite 4300

Las Vegas, NV 89101

Sabrina D. Lawrence

Environmental Restoration Division

DOE/Nevada Operations Office

P.O. Box 98518, M/S 505

Las Vegas, NV 89193-8518

Monica Sanchez

Environmental Restoration Division

DOE/Nevada Operations Office

P.O. Box 98518, M/S 505

Las Vegas, NV 89193-8518

Paul Gretsky

IT Corporation

2621 Losee Road M/S 439

Las Vegas, NV 89030

Dave Madsen

Bechtel Nevada

P.O. Box $98521 \mathrm{M} / \mathrm{S}$ NTS306

Las Vegas, NV 89193-8521

Southern Nevada FFACO

Public Reading Room

P.O. Box 98521

Las Vegas, NV 89193-8521

1 (Controlled)
3 (Uncontrolled)

2 (Uncontrolled)

2 (Uncontrolled)

1 (Uncontrolled) (Controlled) 


\section{$\underline{\text { Copies }}$}

Rosa Silver

FFACO Public Reading Room Coordinator

P.O. Box 93838

Las Vegas, NV 89193

Northern Nevada FFACO

Public Reading Room

P.O. Box 93838

Las Vegas, NV 89193

U.S. Department of Energy

Office of Scientific and Technical Information

P.O. Box 62

Oak Ridge, TN 37831-0062

Ronald G. Huntsinger

Field Station Manager

U.S. Department of Interior

Bureau of Land Management

P.O. Box 911

Tonopah, NV 89049

Tony Valdes

U.S. Forest Service

Tonopah Range District

P.O. Box 3940

Tonopah, NV 89049-6286
1 (Controlled)

1 ( Uncontrolled)

1 (Electronic)
1 (Uncontrolled)

1 (Uncontrolled) 